Portland State University

PDXScholar

Fall 12-21-2018

\title{
Consciousness Against Commodifcation: the Potential for a Radical Housing Movement in the Cully Neighborhood
}

Cameron Hart Herrington

Portland State University

Follow this and additional works at: https://pdxscholar.library.pdx.edu/open_access_etds

Part of the Urban Studies and Planning Commons

Let us know how access to this document benefits you.

Recommended Citation

Herrington, Cameron Hart, "Consciousness Against Commodifcation: the Potential for a Radical Housing Movement in the Cully Neighborhood" (2018). Dissertations and Theses. Paper 4731.

https://doi.org/10.15760/etd.6615

This Thesis is brought to you for free and open access. It has been accepted for inclusion in Dissertations and Theses by an authorized administrator of PDXScholar. Please contact us if we can make this document more accessible: pdxscholar@pdx.edu. 
Consciousness Against Commodification:

The Potential for a Radical Housing Movement in the Cully Neighborhood

by

Cameron Hart Herrington

A thesis submitted in partial fulfillment of the requirements for the degree of

Master of Urban Studies

Thesis Committee:

Lisa Bates, Chair

Karen Gibson

Robert Liebman

Portland State University

2018 
(C) 2018 Cameron Hart Herrington 


\section{Abstract}

A right to housing is a central iteration of the broader demand for a democratic right to the city. The perpetual housing crisis for lower-income people results from a commodified system in which access to housing is based on the exchange value interests of property owners, rather than a universal right to a decent, affordable home. This system is a pillar of neoliberal urban governance and justified by a hegemonic ideology that equates speculative homeownership with the American Dream. Achieving a right to housing, even at the local scale, requires a radical movement that cultivates individual and collective consciousness, discredits the dominant ideology, and fights for decommodification.

In recent years, grassroots organizing in the Cully neighborhood of Portland, OR, has resisted gentrification and contributed to local housing policy victories. As an activist research project, a survey of existing housing advocates tests the framework of housing consciousness and interest groups developed by John Emmeus Davis (1991), and explores the potential for a radical housing movement in Cully. Across lines of housing tenure, respondents widely agree with a right to housing in the abstract, recognize unjust outcomes of the existing system, and support policies that prioritize housing rights over property rights. Yet many are skeptical of interventions specifically in the homeownership system, and express limited or contradictory understandings of the structural underpinnings of housing injustice. 


\section{Acknowledgements}

I am grateful for the many people who helped me along the way to completing my thesis and degree, beginning with my thesis committee. Lisa Bates patiently encouraged and guided me, and is an role model for how scholarship and academic privilege can serve the struggle for a right to the city. Karen Gibson gave me tough love when I needed it, encouraged my radical approach to community development, and helped refine my research methods. Robert Liebman stuck with me even as he prepared for retirement, and guided my thinking on social movement theory and practice.

Many others at the Toulan School of Urban Studies and Planning taught and challenged me: Professors Nathan McClintock and Jason Jurjevich; classmates Erin Goodling, Jamaal Green, Pam Phan, Shannon Jamison, Dillon Mahmoudi, Anthony Levenda, Fiona Gladstone, and especially Ryan Dann, without whom I would still by wrestling with data analysis for this paper.

My thesis could not have happened without the support and encouragement of my co-workers at Living Cully - Tony DeFalco, Anna Gordon, Malin Jimenez, Brenna Bailey, Jess Faunt and Carol Chan - nor without the community members who allow me to join in their struggle for a right to housing.

And finally, none of this (grad school, thesis, the navigation of daily life) would be possible without the love and care of my parents, Linda Hart Herrington and Gregg Herrington, and my wife, Kanna Hudson. 


\section{Table of Contents}

Abstract

Acknowledgements ii

List of Tables $\quad$ iv

List of Figure $\quad v$

Introduction: This is Not Impartial Research 1

Chapter 1: Right to the City, Right to Housing 10

Chapter 2: The Problem: A Perpetual Housing Crisis 16

Chapter 3: The Solution: Decommodify Housing 28

Chapter 4: Implementing the Solution: A Radical Housing Movement 35

Chapter 5: A Model for Community Organizing to Decommodify Housing 39

Chapter 6: The Cully Neighborhood Context 47

Chapter 7: The Housing Movement in Cully 53

Chapter 8: Cully Housing Advocacy Survey 70

Chapter 9: Survey Content and Analysis Plan 76

Chapter 10: Survey Results $\quad 80$

$\begin{array}{ll}\text { Chapter 11: Survey Analysis } & 94\end{array}$

Conclusion: Implications for Organizing and Future Research 112

$\begin{array}{ll}\text { References } & 120\end{array}$

Appendix A: Cully Housing Advocacy Survey (data collection instrument) 126

Appendix B: Data Analysis Model 136 


\section{List of Tables}

Table 5.1 / housing interests $\quad 41$

Table 5.2 / objective housing interest groups 41

Table 5.3 / revised housing interest groups, including future aspirations 43

$\begin{array}{ll}\text { Table } 10.1 \text { / age groups } & 80\end{array}$

$\begin{array}{ll}\text { Table } 10.2 \text { / survey language } & 80\end{array}$

$\begin{array}{ll}\text { Table } 10.3 \text { / race and ethnicity } & 81\end{array}$

$\begin{array}{ll}\text { Table } 10.4 \text { / gender } & 81\end{array}$

$\begin{array}{ll}\text { Table } 10.5 \text { / current housing tenure } & 81\end{array}$

Table 10.6 / housing interest group (current tenure + future goal) 81

Table 10.7 / motivations for initial involvement in housing advocacy 83

Table 10.8 / mean scores, Section 5D: Recognition of inter-group conflict 92

Table 10.9 / mean scores, Section 5A: Housing Justice Ideology 93

Table 11.1 / composite scores for stages of housing consciousness 102

Table 11.2 / support for housing market interventions 110

$\begin{array}{ll}\text { Table 11.3 / Q6.6 } & 110\end{array}$ 


\section{List of Figure}

Figure 11.1 / composite scores for stages of housing consciousness 
Introduction

\section{This is Not Impartial Research}

I am not an impartial researcher. I am an activist and organizer who works alongside low-income people to fight for stable and affordable housing in the face of gentrification, displacement and housing insecurity. I approach my organizing work, and my activist scholarship, from a decidedly political and biased starting point: I believe that housing should be a universal human right; every person should have a decent home.

The fact that this right does not exist in practice, and that, to the contrary, poor people in the United States have always faced a "permanent housing crisis" (Marcuse and Keating, 2006) that results in mass homelessness and other forms of precarity, leads me to believe that the entire housing system needs to be radically changed, not just tweaked or reformed. Therefore, I turn to critical theory to understand the root causes of an unjust housing system, and to help excavate the emancipatory possibilities hidden within it (Brenner, 2009).

A right to housing does already exist, but it is an exclusive right that belongs only to those who can afford to buy it. The simple and evident truth which I discuss in chapter 2, but hope not to overly complicate or theorize - is that "commodification of housing is the underlying problem" causing housing insecurity in the United States (Marcuse, 2012). Two contradictory imperatives are at odds in our commoditized system: 1) Some people want to make a profit 
by owning housing; 2) All people want to live in a decent home that they can afford. In other words: 1) Housing is a market commodity - produced only when it is profitable to do so, and consumed only by those who can pay more than someone else is willing or able to pay; and 2) Housing is a human need - every person has the same basic requirement to be housed.

Our current housing system incentivizes and legally protects the former imperative, while only marginally attempting to address the latter - and then marginalizing and criminalizing those who lose out in the ensuing competition. This commodity system itself, then, does not work if the goal is universal housing.

Transformation of the housing system is not a job for the real estate industry that created and benefits tremendously from the status quo. Neither will large-scale decommodification be carried out by the independent volition of the local state, which is heavily invested in perpetuating the current housing system as part-and-parcel of its general neoliberal orientation (Logan \& Molotch, 1987; Hackworth, 2007; Hern, 2016). That does not mean, however, that the state's role in achieving a right to housing is anything less that indispensable. Similarly, non-profit affordable housing developers wield tools that must be part of the solution, but their co-dependent relationships with the for-profit system and the state make them unlikely to act as the catalysts and drivers of radical change (Stoecker, 1997; 2003). 
I concur with the consensus of critical community development scholars who argue that decommodification at a significant scale will only come about when communities realize and channel their inherent, though generally unrealized, grassroots political power toward transforming the system (e.g. DeFilippis, 2004; Gunn \& Gunn, 1991; Stoecker, 1997; Cummings, 2001). Radical change can happen in piecemeal manner, bit by bit, through a series of "nonreformist reforms" (Fainstein, 2010) that remove land and housing from the market and exert progressive regulation over that which remains privately owned. As Marcuse (2012, p. 223) puts it, "Every step that limits the commodified character of housing contributes to solving the housing crisis."

\section{Purpose, approach and research questions}

Local-scale housing movements, even in the context of the United States' hyper-commodified housing system, have achieved local-scale decommodification of housing (e.g. Medoff \& Sklar, 1994; Stoecker, 1994; Tracy, 2014; Baranski, 2007; Goldman \& Brodsky, 2008; Rooney, 1995). Inspired by these examples, the purpose of my research is to support the development of a radical housing movement - one that can drive the decommodification of housing at the neighborhood scale, but also contribute to a broader social movement that achieves a right to housing at larger scales.

Over the past three years, hundreds of residents of the Cully neighborhood in northeast Portland, Oregon, have participated in housing 
advocacy campaigns organized by the non-profit community development coalition Living Cully ${ }^{1}$. These campaigns have included defensive fights to prevent mass displacement at specific rental properties, and policy campaigns to establish new renters' rights, preserve mobile home parks, and build new affordable housing. To use Marcuse's terminology, these campaigns have succeeded in limiting the commodified character of thousands of units of housing in Portland.

The overarching, motivating question behind this study, then, is how a nascent affordable housing advocacy base in the Cully neighborhood can be cultivated into a radical housing movement aimed at decommodifying this most basic element of urban life. I want to know if the roots of a radical housing movement are already growing, and what potentials are hidden but ready to germinate. And then, what strategies and practices should organizers use to help that movement emerge from the soil?

A radical housing movement in Cully will not be starting from scratch. It will be built from whatever foundations have already been laid through three years of organizing, and whatever baseline of critical consciousness already exists among people who are currently fighting back against displacement and advocating for affordable housing. This study, therefore, is concerned with individuals who are already involved in Living Cully's housing advocacy.

1 The author is employed by Living Cully as a community organizer, and this research is designed as a community-engaged project that will provide findings that are immediately relevant to movement-building efforts in the Cully neighborhood and beyond. 
Residents belonging to three "housing interest groups" (Davis, 1991, ch. 4) have participated in these efforts: renters, homeowners, and residents of manufactured housing parks ${ }^{2}$. By analyzing data from 104 survey respondents, I seek to answer five questions about Cully's housing activists:

- Why are they involved in housing advocacy?

- Do they subscribe to hegemonic notions of homeownership as an investment commodity?

- To what extent have they developed "radical housing consciousness" that leads them to see unjust housing outcomes as symptoms of an unjust system?

- What measures to decommodify housing do they already support?

- What are the limits to solidarity among neighbors, across lines of housing interest group?

By exploring the baseline ideologies, interests and priorities of Cully's existing affordable housing activists, this research informs my own community organizing practice, as well as that of my colleagues and collaborators in the Cully neighborhood. While I believe that my findings will be relevant for other community-based organizations in Portland and beyond, my goal is not necessarily to create generalizable conclusions, but rather focus on insights specific to the context of grassroots organizing in Cully. In this way, my inquiry seeks to follow the spirit of the activist research model articulated by anthropologist Charles Hale:

2 Per Davis (1991), these three groups have a significant accommodation/use-value interest in housing. Other housing interest groups - specifically those with primarily an accumulation/exchange-value interest in residential property (e.g. developers, landlords, financiers) - are not represented among Living Cully's housing activist cohort. 
Activist research: a) helps us better to understand the root causes of inequality, oppression, violence, and related conditions of human suffering; b) is carried out, at each phase from conception through dissemination, in direct cooperation with an organized collective of people who themselves are subject to these conditions; c) is used, together with the people in question, to formulate strategies for transforming these conditions and to achieve the power necessary to make these strategies effective. $(2001, \mathrm{p} 13)$

Starting in Cully, this research seeks to help communities understand their own objective interests and subjective priorities for housing, and expose the failures of the existing housing system to fulfill those interests and priorities. So even though this is not impartial, unbiased research, its validity as activist research does not depend on those traditional standards. It is valid if it provides useful and accurate information for organizers and communities that are building a social movement to achieve a right to housing for low-income people.

\section{Overview of this thesis}

This paper addresses a concrete problem: precarious access to housing for low-income people in the Cully neighborhood. I argue that this problem is a microcosm of the same problem at the national and global scales, symptomatic of an unjust commodity housing system, and one that will only be substantially addressed through a radical social movement. The purpose of the paper is to assess the potential for such a social movement to emerge and flourish in Cully, which I hope will also provide insight for movement-building efforts beyond this one neighborhood. This document is arranged as follows: 


\section{Chapter 1: Right to the City, Right to Housing}

While urban space is always socially produced, it is predominantly privately owned and controlled. The actually existing right to the city is therefore exclusive and appropriated, rather than universal and democratic. The right to housing is a central element of the right to the city. The phenomenon of gentrification exposes the lack of democratic rights to the city and to housing.

\section{Chapter 2: The Problem}

The widespread lack of decent, affordable housing has deep structural roots in an under-regulated capitalist system that creates wealth for the few at the expense of housing insecurity for the many. This system is propped up by a hegemonic ideology that links the provision of housing with faith in the free market, and celebrates homeownership as fulfillment of a virtuous American Dream. The state perpetuates this ideology, while reproducing the unjust system through pro-growth interventions such as gentrification.

\section{Chapter 3: The Solution}

The decommodification of housing will allow it to be provided based on people's universal need to be housed, rather than capitalists' interest in maximizing their wealth. This can happen through interventions that place housing under community-control and regulate whatever remains market-based. 


\section{Chapter 4: The Challenge of Implementing the Solution}

While the solution is simple, implementing that solution is not.

Decommodification is a radical solution (i.e. it address the root causes of a systemic problem) that will only be achieved through a radically-oriented social movement.

\section{Chapter 5: A Model for Community Organizing to Decommodify Housing}

In order to adopt a radical vision for a right to housing and organize to achieve it, individuals must develop consciousness about the reality of the existing housing system, their interests within it, and the potential to bring about an alternative system that provides stable housing for all.

\section{Chapter 6: The Cully Context}

The Cully neighborhood is home to low-income people who have arrived from all over the world, including African-American families displaced by gentrification from other Portland neighborhoods. Gentrification is now reaching Cully, and market-based affordable housing is disappearing. Living Cully is working to prevent displacement of low-income residents and people of color and expand access to permanently affordable housing.

\section{Chapter 7: The Housing Movement in Cully}

Living Cully has spearheads community organizing focused on antidisplacement and affordable housing, which has contributed to the preservation 
of thousands of affordable homes throughout Portland. This organizing has involved hundreds of people across lines of housing tenure, race and age. Yet this movement has left out African-Americans and other racial and ethnic groups, and has not developed the systemic analysis and radical consciousness that would enable the emergence of a radical housing movement.

\section{Chapters 8, 9, 10, 11: The Cully Housing Advocacy Survey}

In order to examine the potential for a radical housing movement to emerge, 104 existing housing activists in Cully responded to a survey that assesses their interests, priorities and ideologies with relation to housing. Respectively, these chapters discuss: the purpose and mechanics of the survey; the survey content and data analysis approach; survey results; the implications of those results for ongoing community organizing and movement-building.

\section{Conclusion: Implications for Organizing and Future Research}

The five research questions posed earlier in this chapter are revisited and discussed in light of data collected through the Cully Housing Advocacy Survey. Limitations of the current study are discussed, along with suggestions for further research. 


\section{Chapter 1}

\section{Right to the City, Right to Housing}

The 'right to the city' - a concept first articulated by Lefebvre in the 1960s and subsequently adopted, appropriated, and championed by urban social movements worldwide - is not a 'right' in the classical, liberal, legal sense of that word (Mayer, 2012). Rather, it is precisely a concept; a powerful yet diffuse political idea that broadly entails greater democratic control over the city (Purcell, 2002). The right to the city is, in Harvey's view, a rallying cry - a principal that has been adopted by social movements around the world as "a working slogan and a political ideal” (Harvey, 2012, p. 25) used to advance more concrete proposals for the democratization, as opposed to commodification, of urban life.

Though he did not employ the right to the city terminology, Castells identified the same basic political goal as a common thread uniting urban social movements across history, concluding that such movements commonly coalesce as a form of "resistance to the commodification of the material basis of everyday life" (Castells, 1983, p. 69). For Lefebvre, the antithesis of commodified urban life is democratic control over all those decisions that affect the production of urban space $^{3}$, whether those decisions are currently the purview of established state structures or not. "The investment decisions of firms, for

3 Purcell explains that Lefebvre's notion of urban space entails both the physical space of a city and the "mental constructions," "creative ideas" and "representations" of that space. "It involves producing and reproducing all aspects of urban life" (Purcell 2002: 102). 
example," Purcell explains, "would fall within the purview of the right to the city because such decisions play a crucial role in producing urban space" (2002, p. 102).

It follows, then, that Lefebvre redefines urban citizenship - the basis for democratic participation in the production and governance of urban space - as belonging to all those who inhabit the city. Under a right to the city framework, the ownership of space and other forms of privileged economic and political power would no longer grant the right to make decisions about urban space. Furthermore, Lefebvre's citizenship is based on inhabitance, rather than formal national citizenship. Enfranchisement, in his conception, "is not an accident of nationality or ethnicity or birth; rather it is earned by living out the daily routines of everyday life in the space of the city" (Purcell, 2002, p. 102). Working in concert, these two expanded notions of enfranchisement grant those who contribute to the daily production of urban space - inhabitants, by virtue of their daily life in the city - control over the decisions that shape and reshape that space.

While the right to the city concept is most prominently used to express aspirations for an alternate, radically democratic urban future, it can also be used as a framing for the exposition of existing conditions. In the latter sense, the concept describes an actually existing power structure in which control and decision-making are predominantly in the hands of the legally-sanctioned 
owners and shapers of urban space - the landlords, speculators, developers and other drivers of the urban growth machine (Logan \& Molotch, 1987).

This is a machine that turns urban space into a commodity and transforms use-values into exchange-values. In the existing order, decisions about the city's present and its future are made by those with the financial and political capital required to drive the machine:

The actually existing right to the city, as it is now constituted, is far too narrowly confined, in most cases in the hands of a small political and economic elite who are in a position to shape the city more and more after their own particular needs and hearts' desire. (Harvey, 2012, p. 24)

Any democratic right to the city that inhabitants might hope to claim stands to be subsumed by the prerogative of property owners and capitalists to seek private gain from commodified urban space.

Yet, in its aspirational iteration, the right to the city still rings out as a rallying cry from the grassroots, as an overarching demand, and as the ideological basis for an imagined and radically different arrangement of power and control over the city. It is the demand for decision-making power to be allotted not on the basis of ownership, but on the basis of inhabitance. If the right to the city is the right to shape and decide about the city, it must belong collectively to the inhabitants whose lives create the city and create all value that it entails. The political demand for a 'right to the city' is therefore a demand that the right to control and shape the city be democratized and vested in those who inhabit the city and make it run, rather than those who merely own it. 
As an ideology of democratic, collective control, the right to the city is perhaps necessarily under-defined. Part of its potential energy is its potential application to all facets of urban life. Yet this potential energy can become kinetic when the concept is applied to concrete claims by organized people. Specific demands for specific rights can and must accompany the broader conceptual demand. And any meaningful conceptualization of a general right to the city must include at its core a very tangible and basic demand for inhabitants to actually inhabit the city, without being displaced from it. The right to the city must entail a right to housing.

Housing is the central locus of urban life - and therefore central to any right to the city. Control over housing equates to control over land, the most fundamental form of urban space (Hern, 2016). Land literally defines the city, but is also the repository of its value - both its use value for people, and its exchange value for capital. Access to land and housing provides access to all other facets of daily urban life and shapes claims of citizenship and participation. Housing entails a home, autonomy, community, and a base from which to exercise and organize for other rights.

\section{Gentrification and the right to the city}

In gentrifying urban neighborhoods, these rights - to housing and to the city itself - are dramatically concentrated in the hands of the few. Gentrification exposes the unapologetic distribution of rights to the city on the basis of racial- 
political-economic privilege. The urban growth machine - private capital and the local state conspiring to capitalize, redevelop, market and police urban space strips the rights of inhabitance and use of urban space from those who previously belonged, and bestows those rights upon a more preferred class.

Gentrification goes beyond redevelopment; is a project of commodifying not only specific urban addresses (redeveloping a disinvested apartment building, for example), but entire neighborhoods. The target is a neighborhood where the commodity value of property is low, but can be increased by removing current residents and replacing them. Buy low, sell high. The potential future commodity value of the neighborhood is a function of its desirability as a space of consumption for those with greater purchasing power (Beauregard, 1986), which almost always means well-educated whites.

Conveniently, that desirability is itself derived largely from racial exclusion - the establishment of white (anti-black) cultural and consumer spaces - along with access to racially appropriate urban amenities. So, the best neighborhoods to gentrify - those with the largest gap between current profitability and potential future profitability - are those where poor black and brown residents can be replaced with rich white ones. Housing is central to all of this: it is a commodity, a means of legally- and economically-mediated spatial/racial control, and a point of access to racially-coded spaces of consumption and amenity. 
This dominant system of providing and controlling access to urban space and to housing is inherently antithetical to the 'right to the city' political project. Commoditized neighborhoods and commoditized housing result from an eliteheld right to shape the city, with that shape being one in which the right to use the city goes only to those who can pay the most for it. These actually existing rights to the city and to housing are therefore not only exclusive, but monopolistic. The city's owners/developers/decision-makers have privileged access to their own housing and neighborhoods, yet also control the ability of other people to have homes and neighborhoods where they can belong. 


\section{Chapter 2}

\section{The Problem: A Perpetual Housing Crisis}

The United States has a permanent affordable housing crisis, in which there has never been sufficient decent housing available for the poor at prices they can afford (Marcuse \& Keating, 2006). The evidence of this crisis is overwhelming and unequivocal. Over 500,000 people nationwide are homeless (Gee, 2017) - which is fundamentally a housing market outcome (Wright, Rubin \& Devine, 1998), despite widespread and vociferous victim-blaming (Willis, 2016). Evictions are rampant and contributing to a steady trickle-up of wealth from the poor to the property owners (Hartman \& Robinson, 2003; Desmond, 2016). Gentrification and displacement are tearing apart communities, (re)segregating cities and exacerbating entrenched racial inequalities.

Of course these outcomes are piling up even after people spend whatever they can and must in an attempt to stay housed. Millions of low-income families in the United States, perhaps as many as one-third of all households, are able to maintain their housing only by paying so much that they are forced sacrifice other basic necessities such as food and healthcare (Stone, 2006). But all too often, and especially in booming markets like Portland's where the rising cost of housing far outstrips stagnant incomes, even entire paychecks ultimately aren't enough to compete. More and more families spend more than they can afford on housing, even as they are pushed to the outer fringes of the city. 
People of color in particular are now excluded from massive swaths of urban space - or, in other words, preemptively displaced from the opportunity to access housing in neighborhoods where housing costs have increased (Newman \& Wyly, 2006). The most recent data from the Portland Housing Bureau demonstrate that families earning the average income for AfricanAmerican, Latino and Native American households cannot afford to rent a twobedroom apartment or purchase a home anywhere within the city limits, without spending more than $30 \%$ of monthly income on their housing (Portland Housing Bureau, 2017, p. 9).

And let us not forget the near-collapse of the global economy in 2008 , triggered by mass foreclosures and the bursting of a speculative housing investment bubble. Millions lost their homes and their life savings, demonstrating the precariousness of homeownership as a reliable wealthbuilding strategy (Thaden, Greer \& Saegert, 2013) and resulting in a massive flow of wealth from low-income people to banks and other investors (Harvey, 2012). African-Americans and other people of color were particularly victimized, having been disproportionately subjected to predatory lending practices and lacking the accumulated intergenerational wealth that helped many white families weather the storm.

In summation, the housing system in the United States consistently and rampantly produces unjust outcomes: homelessness, evictions, poverty induced 
by high housing costs, foreclosures and market crashes, and gentrification and displacement.

\section{A machine that makes crisis}

This degree of mass housing insecurity exists because housing is treated primarily as a commodity in our political-economic system, rather than a basic human right. The production and use of housing are first and foremost market transactions, rather than responses to the human need to be housed. An investment in rental housing is made not for the purpose of providing housing, but because "it enables its owner to use money to make more money, to invest and accumulate capital" (Barton, 1977, p. 21).

In other words, housing is produced and distributed on the basis of speculative exchange values, rather than use values (Logan \& Molotch, 1987; Davis, 1991; Marcuse, 2012). This is the case despite the fact that the basic use values of housing - shelter, security, social reproduction - are indispensable for human beings (Hartman, 1998). The central contradiction of our housing system, therefore, is this dual nature: housing is produced and exchanged as a speculative investment, yet it is also a basic human need ${ }^{4}$.

When the two sets of interests are in acute conflict (as with a foreclosure or a tenant's inability to afford a rent increase), the commodity function takes legal priority. In eviction court, a landlord's argument that "the tenant didn't pay

4 I can think of no other speculative investment commodity (jewels, fine art, antiques, gold bullion, etc.) that is also a basic necessity of life. 
rent" wins the case against a tenant's plea that "my family needs a place to live." That this legal outcome reflexively strikes me as inherently correct, even now as I am writing in support of a right to housing, demonstrates the hegemonic reach of the logic of commoditized housing.

Of course, the commodity value of housing does not appear out of thin air. The housing system is fundamentally a zero-sum affair. The wealth of some is produced by extracting wealth from others. Increased property values for homeowners and rental revenues for landlords come out of the pockets of homebuyers and tenants, respectively. This facet of the housing system is obscured by the promotion of homeownership as a 'wealth-building' mechanism, rather than a more accurate framing of homeownership as a 'wealth-transferring' mechanism. After all, the building of wealth for some is in direct inverse proportion to the loss of wealth or exclusion from the homeownership market for others:

But this sort of wealth building is predicated on a never-ending stream of new people who are willing and able to pay current home owners increasingly absurd amounts of money for their homes. It is, in other words, a massive up-front transfer of wealth from younger people to older people, on the implicit promise that when those young people become old, there will be new young people willing to give them even more money. And of course, as prices rise, the only young people able to buy into this ponzi scheme are quite well-to-do themselves. (Hertz, 2016)

When real estate goes to the highest bidder - whether that be apartments for rent, houses for sale, or the land under a mobile home park being sold for redevelopment - the poor are at risk of being displaced both from both their 
actual, current homes, and from the opportunity to access housing in the future. The "effective demand" of those with more will always eclipse the "ineffective demand" of those with less (Marcuse, 2012). This result is predictable when the housing industry is allowed (no, incentivized) to single-mindedly pursue its logical interest in maximizing profits. Those who cannot create sufficient profits for this industry are left out - especially in gentrifying neighborhoods, where speculative land values and seductive rent gaps preclude the exchange of housing at affordable-to-the-poor prices.

When some housing does 'trickle-down' and become affordable to the poor - whether through accident of circumstance, malicious slum-lording, or the racist practices of targeted disinvestment - the stage is set for speculative investors to capitalize on the situation by returning property to its 'highest and best use.' Steve King, executive director of the Oakland Community Land Trust, takes issue with the label sometimes applied to this trickle-down housing $\mathrm{NOAH}$, or naturally occurring affordable housing:

This housing stock is most often found in lower-income neighborhoods and communities of color where decades of disinvestment and uneven development has unnaturally nurtured an "untapped market" ripe for speculative reinvestment. It may be unsubsidized and affordable for now, but it is also under-maintained and precarious, with eviction and displacement a palpable, everyday threat. (King, 2017, emphasis in original)

Whatever affordable housing happens to exist in a hot real estate market, therefore, is inherently precarious (Barton, 1977). It may be momentarily, 
circumstantially affordable because it is cheap for a landlord to operate disinvested housing, but only remains affordable until there is sufficient profit to be made through evictions and redevelopment. This window of temporary affordability is especially fleeting in a gentrification context, with rising land values and rents incentivizing landlords to displace existing residents in order to make way for the gentry.

\section{The ideology that validates an unjust system}

Though the statistical and anecdotal evidence of an unjust housing system is ample, specific instances of housing insecurity are often hidden from view. Housing crises are too-often dealt with discreetly by households, one-byone, as they make decisions to set aside other needs to make rent or mortgage payments, or to move out of housing that is unaffordable. Evictions and foreclosures are similarly seen as private matters, and as the just consequences for households that fail to have enough money to afford housing (e.g. Monello Schloming \& Schloming, 2003). Public housing residents are sequestered away in projects. The homeless, for their part, are made invisible, criminalized, and held responsible for their own condition; homelessness is explained away as anything but a housing issue (Wright, Rubin \& Devine, 1998). Especially at the national level, the perpetual lack of decent, affordable housing is routinely accepted as natural and politically palatable, if not just and fair.

According to Peter Marcuse (2012), this commodity system of housing is 
justified and normalized by a hegemonic, three-part national housing ideology: 1) Housing should be provided almost exclusively through the private market; 2) The state should not regulate that market; and 3) Housing functions as an investment and the preferred vehicle for household wealth creation through the American Dream of homeownership. This ideology has been vociferously espoused across the political spectrum for literally centuries (Madden \& Marcuse, 2016, p. 74-75), and both reflects and shapes the housing desires of most U.S. residents (Streitfeld \& Thee-Brenan, 2011).

The actually existing housing system is not broken; it is working exactly as it was designed (Marcuse, 2012). It creates massive profits for a massive, multi-sector industry that produces, finances, operates and gambles on the commodity called housing. This system continues to operate, despite its obvious inequitable outcomes, in part because it is propped up by an ideology promising the American Dream of stability, privatized spatial control, and wealth creation through homeownership, "a magical form of tenure that 'transforms' the occupant'” (Madden \& Marcuse, 2016, p. 75).

Maintaining this ideology serves the structural interests of a neoliberal urban grown machine (Dreier, 2006; Marcuse \& Keating, 2006; Davis, 1991). It is an ideology that transforms shelter, a basic necessity of human life, into capital - wealth that exists in order to create more wealth. Outside of the industries that designed and operate the system, enough people continue to benefit from it, 
namely homeowners who stand to gain from the windfall profits of gentrification, to seemingly validate its promise of upward mobility.

However, there is significant evidence that this system of private property ownership, while functioning brilliantly for the industry that designed it and a privileged minority of homeowners, does not provide stable, affordable housing for most people. At its very roots, it disproportionately excludes people of color - most notably African Americans, who have been always been systematically denied and/or stripped of the opportunity to own homes (Gibson, 2007; Rothstein, 2017; Squires, 1994; Fullilove \& Wallace, 2011). Across the board, lower-income households who might hope to become homeowners in the future face daunting circumstances; the cost of buying a home continues to rise, yet service sector wages don't.

Nonetheless, as recently as 2011 - in the immediate aftermath of the foreclosure crisis - nine in ten people in the U.S. remained enamored enough of the system as to want to become homeowners (Streitfeld \& Thee-Brenan, 2011).

\section{Gentrification and the role of the state}

The displacement of low-income households from gentrifying neighborhoods exposes the injustice of a system that treats housing akin to any other commodity, despite housing's special character as the very locus of social reproduction (Hartman, 1998). As a predictable and serial phenomenon, and one built on blatant racial injustice, gentrification further calls into question our 
reliance on an under-regulated, speculative market to provide what many countries regard as a basic human right.

While it is often shrugged off as an inevitable if unfortunate side effect of long-needed neighborhood revitalization, gentrification can more accurately be understood as an intentional demand-side economic development strategy of the local state (Smith, 2002). Gentrification is no mere byproduct of development in disinvested neighborhoods. Rather, in the neoliberal city, it is the implicit (and only thinly-veiled) goal of such development, and the means by which profit is realized from it (Hackworth, 2007). In a vicious, speculative cycle, the mere prospect of incipient gentrification is a magnet for capital. The goal of gentrification capital is to attract wealthy consumers with housing and amenities catered to their consumption demands (Beauregard, 1986). Gentrification and 'revitalization' are not only co-occurring, they are two names for the same thing.

The targets of gentrification capital are undervalued neighborhoods undervalued in the sense that they are home to low-income people whose levels of consumption do not provide optimal returns on investment. The fact that existing residents are often people of color, and that existing businesses serve their consumption demands, further limits profit-making under the neighborhood's existing configuration. Speculative capital flows into such neighborhoods, exploiting a "rent gap" (Smith, 1987) that has opened up between the existing property use and the potential profit that can be realized 
by selling urban space to new residents with more purchasing power.

Rising rents force out renters. When homeowners sell, escalated property values ensure that the buyers will be from a higher-income group than the sellers. Such sales create windfall profits for individual families that owned homes prior to gentrification, but at the community scale are part-and-parcel of displacement. Businesses that served previous residents close down or move, and new businesses move in that cater to the white and the wealthy.

To be sure, gentrification is a chaotic, complex process (Beauregard, 1986) that exists at the nexus of historical forces, racial injustice, policy at various scales of governance, public and private investment, urban planning, the real estate and housing markets, regional demographic change, migration patterns, and the dynamics of the broader political-economy. Yet, at the same time, gentrification is eminently simple and predictable. No matter the exact mix of forces that sets the stage in any given place and time, by definition gentrification consists of higher-income households, and the businesses that cater to their consumption demands, moving into a formerly lower-income neighborhood. Supply and demand are brutally effective: wealthy households' demand for housing increases, property values and rents go up, and lowincome households and the business that serve them are priced out.

Though state intervention in the housing market on behalf of the poor is politically anathema, local government regularly acts to support the interests of 
capital, which includes facilitating gentrification through subsidies for developers, infrastructure investments and urban renewal schemes. Describing the history of public sector involvement in the urban economy, Squires states that "growth has been the constant, central objective" (1994, p. 92). Rather than mitigate the unjust outcomes of the speculative property market, the neoliberal local state helps that market to operate more intensively (Stoecker, 1994; Logan \& Molotch, 1987). This occurs through the dual strategies of "rolling back" the existing safety net and social welfare functions of the state, and "rolling out" growth-oriented policies that facilitate capital accumulation (Hackworth, 2007).

Gentrification takes on the quality of an arms race, as cities compete against each other at a global scale to attract globally-circulating capital, with growth the goal in and of itself:

Hypercompetitive cycles of competition to attract and retain capital require cities to feverishly marshal and deploy arrangements of tax relaxations, incentives, urban branding and marketing, mega-events and capital-friendly social regimes in order to lure investors, tourists, speculators, head offices, banks - anyone with significant capital is heartily welcomed pretty much anywhere at any time. (Hern, 2016, p. 51)

The displacement of low-income residents - and their replacement with households that can produce greater profits for capital through their consumption of more expensive housing, goods and services - makes investment in gentrifying neighborhoods lucrative for footloose capital. Or, as Neil Smith has put it, "Gentrification as global urban strategy is a consummate expression of neoliberal urbanism" (2002, p. 99). 
In Portland, to cite just one example, the local government's willful, decades-long neglect of basic infrastructure needs and refusal to ensure basic livability and public safety helped produce the unnatural occurrence of disinvested properties and substandard housing in the predominantly AfricanAmerican neighborhoods of the Albina District (Gibson, 2007). Thus devalued, land was confiscated from property owners, predominantly African-Americans, through eminent domain in order to make way for a freeway, hospital and sports arena during the 1950s-'70s.

Once property values are sufficiently depressed and a significant rent gap exists, urban renewal and other nefarious public sector schemes can prime the pump and incentivize the flow of private "cataclysmic capital" (Jacobs, 1961, ch. 16) into targeted neighborhoods, with increased property tax revenues for the state being a fortuitous side effect. In this gentrification phase of the Black community's dismantling in Portland, beginning in the early 2000s, the city's sweetheart deals for private developers and investments in amenities catering to affluent newcomers added fuel to the fire of a red-hot housing market (Herrington \& Dann, 2016). In Albina and urban neighborhoods worldwide where similar processes unfold, existing residents lose their homes one way or another - by means of overt appropriation of their properties, or through the more subtle workings of a state-abetted housing market. 


\section{Chapter 3}

\section{The Solution: Decommodify Housing}

The unjust outcomes of the United States' housing system are well understood and predictable. But that does not mean that they are inevitable. If a rich society wants something to be universally available it can make it so, as the United States does so with a number of public goods: roads, schools, libraries and parks are free for all to use. In other wealthy countries, health care is provided as a public good and basic human right. There is no practical or technical reason that housing cannot be similarly provided on the basis of need, rather than the basis or purchasing power.

In many rich countries, in fact, the state does intervene heavily in the market in order to make housing broadly affordable. Alongside progressive regulation of market-based housing, many European countries have massive social housing sectors, providing homes not only for the poor, but also the middle class. In the Netherlands, for example, $32 \%$ of the total housing stock and $75 \%$ of all rental housing is non-commodity social housing, owned and operated by non-profit providers that are financed by the national government (European Federation of Public, Cooperative and Social Housing, 2010).

It's not just European social democracies that treat housing as a public good. In Singapore, a nation ranked second in the world on the right-wing Heritage Foundation's Index of Economic Freedom, over $80 \%$ of the population 
lives in housing owned by the government (Bruenig, 2018). Yet in the United States, despite "the demonstrable inability of the mainstream, for-profit housing sector to provide decent, truly affordable housing for low-income people," the federal government abdicates its prerogative to do so. Only $4 \%$ of the U.S. housing stock is in some form of social ownership, comprising both public and non-profit owners (Stone, 2008, p. 67).

The federal Housing Act of 1949 envisioned "the realization as soon as feasible of the goal of a decent home and a suitable living environment for every American family." This timeframe of "as soon as feasible" has now reached nearly 70 years. The Housing Act's preambulatory lip service notwithstanding, a right to housing was "never even marginally considered" by Congress in 1949 (Marcuse \& Keating, 2006, p. 144). Since the 1980s, the federal government has dramatically decreased its already paltry social housing spending, including public housing administered through the Department of Housing and Urban Development (HUD), Section 8 vouchers, and tax credits. Seeking to get the federal government out of the affordable housing business entirely, prominent Republicans regularly propose eliminating HUD (e.g. Weiner, 2012). Meanwhile, the mortgage interest tax deduction for wealthy homeowners dwarfs all other federal housing expenditures (Dreier, 2006, p. 116).

In a context of federal antagonism toward low-income people who need affordable housing, state and local governments can (and many do) try to pick 
up the slack by prioritizing affordable housing within their municipal budgets. Yet the local state remains preternaturally committed to the urban growth machine mode of governance, and is therefore loathe to intervene in the commodity housing system by enacting profit-reducing regulations, or to tax capital and real estate profits at levels that could provide for a necessary scale of social housing (Logan \& Molotch, 1987; Hackworth, 2007).

Ultimately, the limited provision of social housing in U.S. cities has proven insufficient to sweep back the tide of housing insecurity. Columbia University's Lance Freeman, notorious for research findings suggesting that gentrification does not cause displacement any faster than the normal rate of residential mobility, inadvertently exposed the systemic foundations of the permanent housing crisis in a 2014 interview with New York Magazine:

If we are going to allow housing to be a market commodity, then we have to live with the downsides, even though we can blunt the negative effects to some extent. It's pretty hard to get around that. (Davidson, 2014)

The extremely limited scale of state intervention in the housing market in the United States merely attempts to "blunt the negative effects to some extent." To have any greater effect will require grappling with the first clause of Freeman's statement: "If we are going to allow housing to be a market commodity..."

\section{Community-control of decommodified housing}

Because "commodification of housing is the underlying problem" (Marcuse, 2012), the radical solution is decommodification. First, remove as 
much land and housing as possible from the commodity system once and for all. This means public sector ownership or direct community-control of residential property via cooperatives, non-profits, and land trusts. Second, enact regulations that "limit the commodified character" (Marcuse, 2012, p. 223) of whatever housing remains privately owned. Such regulations should prioritize affordability and stability over profit and wealth-building. Housing can be more affordable if it is a worse (i.e. less-profitable) investment (Hertz, 2016).

Michael Stone (2008) defines non-commodity social housing as that which 1) is not owned and operated for profit; 2) cannot be sold for speculative gain; and 3) provides security of tenure for residents. Stone identifies four categories of social housing in the United States:

1. Public rental housing, owned by public housing authorities;

2. Non-profit rental housing, primarily developed and owned by community development corporations;

3. "Quasi-nonprofit" rental housing developed with financing from for-profit investors, as through the Low Income Housing Tax Credit program;

4. Non-speculative homeownership, through community land trusts and limited-equity cooperatives.

While each of these models meets Stone's basic definition of social housing in that it provides the security of tenure that comes with affordable, stable rents, there is a wide range of potential community-control arrangements within the non-commodity housing sphere. For tenants, the day-to-day experience of living in public or non-profit rental housing may mirror that of living in market-rate rental housing: lack of control and autonomy over the physical 
space of their homes, with decisions made by an impersonal landlord (Stoecker, 1997). In most cases, non-profit housing development and property management remain technical enterprises that residents are excluded from.

Of course, a non-profit rental housing provider could give tenants more direct control over their homes and the organization that owns them; a tenants' committee could have a role in property management, or seats reserved on the organization's board of directors. But this kind of direct community control over a housing non-profit is exceedingly rare, due to structural contradictions between professional community developers' dependence upon the existing political-economic system and the community's frequent orientation toward fundamentally shifting existing power dynamics (Stoecker, 2003).

At the other end of the spectrum, limited-equity housing cooperatives and community land trusts are often referred to explicitly as 'community-controlled housing.' As with public and non-profit rentals, these models remove land and housing from the private, speculative market in order to keep it affordable. But in addition to being decommodified, this housing is owned collectively by the residents through a non-profit entity, which they have a democratic role in managing. In the case of cooperatives, residents are shareholders in the nonprofit entity that owns an apartment building or manufactured housing park, and pay monthly dues (i.e. rent) that cover the operating costs of the property. In a land trust model, a non-profit entity owns the land, while individual households 
own the homes that are built on that land. In both models, the homes "cannot be sold for speculative gain" (Stone, 2008, p. 67), because sales prices are restricted to keep the homes permanently affordable for all subsequent buyers.

In addition to keeping housing affordable, participation in communitycontrolled models has been shown to help residents build grassroots political power, leadership and civic engagement know-how, which creates collective resilience in the face of threats to housing security and other issues in their neighborhoods (Saegert \& Winkel, 1996). In gentrifying urban neighborhoods, community-controlled housing is a proven anti-displacement strategy (Gallaher, 2016; Barton, 1977; Gray \& Galande, 2011; Saegert et al., 2003; Leavitt \& Saegert, 1990). Community land trusts protect current residents from rising housing costs and foreclosures (Saegert et al. 2003; Thaden, Greer \& Saegert, 2013), and limit community-level displacement for the long-run by maintaining homes as affordable for subsequent generations of low-income residents.

\section{Community-controlled housing and the right to the city}

A cadre of scholars including Gunn and Gunn (1991), DeFilippis (2001; 2004) and Stoecker (1997) advocate for a more robust urban citizenship through community control over "the institutions that structure daily life" (DeFilippis, 2004, p. 2), including housing. Community control can therefore be understood as a concrete proposal advanced under the banner of the right to the city: "If low income and working people want more control over their lives, they need to 
create forms of ownership and governance that allow them to realize that control” (DeFilippis, 2004, p. 10).

The commodification of housing is anathema to a democratic right to the city. The exchange value of property, and therefore housing, is largely determined by its socially produced use value. While an owner can improve her property, its value is largely determined by its location (geographic, social, economic) vis-à-vis the city as a whole, which has nothing to do with the owner's effort or ingenuity. Rather than create value, property owners merely capture and privatize socially produced use values and convert them into exchange values (Davis, 1991).

If for Marx the capitalist system of wage labor alienates workers from the products of their labor, for Lefebvre capitalist urbanization alienates inhabitants from the urban space that they produce. The city itself - which cannot exist apart from the daily lives and struggles of its inhabitants - is appropriated and commoditized as capitalists convert use values to monopoly rents (Harvey, 2012, ch. 4). Under the banner of the right to the city, however, those same inhabitants might create institutions - cooperatives, land trusts and other nonprofit entities - that democratize control over the centrally important spaces of people's homes. There is no more powerful iteration of a right to the city than democratic - rather than capitalistic - control of housing. 


\section{Chapter 4}

\section{Implementing the Solution: A Radical Housing Movement}

Any effort to radically overhaul and decommodify the housing system faces significant political, economic and cultural barriers. Rhetorically and politically, community-controlled (rather than market-controlled) housing is antithetical to the ideology that justifies the housing-as-commodity system (DeFilippis, 2004; Shlay, 2006; Thaden, Greer \& Saegert, 2013).

Opening a bigger political-cultural space for community-controlled housing, therefore, will require forcing open the cracks in the dominant U.S. housing ideology. However, powerful interests are inextricably invested in the existing system of buying and selling land and housing as a speculative investment: banks, realtors, investors foreign and domestic, the construction industry, and even organized labor. The system of commodity housing won't be undone, even at the local scale, without a fight.

\section{The existing system will not undo itself}

Unfortunately, the fight has generally not been forthcoming from the public and non-profit affordable housing sectors, which too often espouse the gospel of speculative homeownership right alongside the realtors; community development corporations often run programs to convert their tenants into private homeowners. We must aim for more than providing subsidies for some poor families to access the exclusionary homeownership market - a tactic that 
proves the rule of an unjust system by helping a select few to be the exceptions.

Even non-profits that administer community-controlled housing can become de-politicized and acquiescent to the dominant system. Community land trusts have radical potential - removing land and housing from the market once-and-for-all is a critique-in-practice of the inherent shortcomings of the market. But CLTs often squander this radical potential by selling themselves (to the community, and to the public- and private-sector funders that they are dependent upon) as nothing more than an apolitical means of affordable homeownership for a lucky few, and abdicating their potential roll as organizers and movement builders (e.g. Gray \& Galande, 2011).

Both the community land trust and the community development corporation emerged in the 1960s as outgrowths of the broader civil rights movement, as radical tools for community-based power and collective wealth (Stoecker, 1997; Cohen \& Lipman, 2016). However, both have too often been handcuffed by a post-political mindset (Swyngedouw, 2007) that limits them to operating within the bounds of the existing system, scrapping against other nonprofits for slices of a dismally small social housing budget.

As Mayer (2012) points out in the context of her analysis of urban social movement groups organizing under the banner of the right to the city, radical agendas to shift existing power dynamics and re-appropriate urban space can become institutionalized and co-opted by the very systems they were intended 
to change. In such cases, organizations end up merely advocating for greater "participation" within the existing status quo, seeking "rights(s) to the city (as it exists)," rather than a transformative right to create "another city" (p. 71-73). In light of these dynamics, the community development literature agrees that radical changes to the housing system, even at a local scale, will only happen as a result of organized political action by people who need and use housing (DeFilippis, 2004; Gunn \& Gunn, 1991; Castells, 1983; Davis, 1991, among others). Changing the status quo is always difficult, and even more so in the context of a local state that operates in concert with capital to perpetuate a neoliberal urban growth machine. Organized people are the only force that can thwart the plans of organized capital.

Organizers and critical urban theorists, therefore, face a political (rather than technical) task of discrediting the ideology of commodity housing (Marcuse, 2012). The technical solutions are known: remove land and housing from the market, and strictly regulate that which remains on the market to ensure affordability and security of tenure. Movement-builders must expose the nature of a housing system that is transforming cities into privileged white enclaves and transferring wealth from the poor to the rich. From this starting point of political consciousness, a vision for an alternative - for a decolonized, decommodified collectivist reshaping of property rights (Hern, 2016), for a right to housing (Hartman, 1998) - can emerge. 
The fight to substantially decommodify land and housing will not come from the state, nor from the affordable housing developers and homeownership assistance programs that are state-dependent and integrated with the commodity housing system. Rather, the fight must come from the renters, the homeless, the foreclosed-upon, the displaced. Non-commodity housing will only be developed at scale if non-property-owning people embrace decommodification as a solution to their own personal and collective housing crises, and then organize to make it happen.

We need a counter-hegemonic movement that can situate the housing instability of individual households within a structural context, so that individual crises can be seen as endemic and symptomatic of a rotten system. This movement must be built on a "radical consciousness" (Davis, 1991) that understands both individual housing instability and community-scale gentrification and displacement as intrinsic to our commodity system. It must put forward a vision for a right to housing for ourselves and future residents of the city. This is a job for critical theorists, organizers and movement-builders: expose the failures of the dominant ideology, and build its alternatives (Brenner, 2009). Land trusts, cooperatives, regulated affordable rentals, and policies that regulate the market will be the tools for decommodification, but the political force to wield these tools at scale will come from the grassroots. 


\section{Chapter 5}

\section{A Model for Community Organizing to Decommodify Housing}

The work for organizers and organizations that are serious about housing decommodification is movement-building through grassroots community organizing. In proposing a framework for community organizing centered on the question of housing, I borrow extensively from the model laid out by John Emmeus Davis in Contested Ground : Collective Action and the Urban Neighborhood (1991). I am particularly interested in the potential for organizing in Cully, with implications for other urban neighborhoods.

\section{Housing interest groups}

Following Davis' lead, I argue that a first, foundational step in the endeavor of building a movement for community-controlled housing is to identify the organizable base of people whose right to housing has been appropriated under the current system, and whose objective interests could be better served by a system of non-commodity housing.

In some kinds of conflicts, the "organizable base" might include everyone within the geography of the neighborhood. In such instances, local communities take action collectively in response to an outside threat that affects all residents (Davis, 1991, p. 7). In Cully, a recent example is the March 2018 fire at an auto salvage yard that threatened the entire neighborhood with dangerous airborne toxins and the potential for the fire to spread widely (Monahan \& Mesh 2018). 
However, threats to housing stability are not outside threats that affect an entire neighborhood in the same way. Rather, the housing system is made up of groups with structurally defined, conflicting interests: "People with different relations to property and place will have different economic and political interests" (Davis, 1991, p. 7). This makes housing a field of conflictual, rather than collaborative, place-based action. Willingness to take action, and what kind of action they are willing to take, is a product of people's objective interests.

Davis' model of structurally-defined, objective housing interest groups is based on six characteristics of interests that he identifies from his reading of Marxist social movement theory. Interests are (p. 18-20):

1. Material: Interests are about concrete things, not preferences or emotions;

2. Objective: Interests exist objectively, prior to the subjective perception thereof;

3. Structural: Objective interests accrue to people and groups based on their position within the structure of capitalist production - or, in the housing context, within the capitalist system of place and property;

4. Collective: Because various people occupy the same structural position, they have the same objective interests;

5. Relational: A group's interests exist in relation to other groups' interests;

6. Antagonistic: Interests of different groups are in a zero-sum relationship; one groups benefits at the expense of another.

There are two contradictory categories of objective interests in residential property: accommodation interests (based on the use value of property as a place to live) and accumulation interests (based on the exchange value of property as a commodity used to make profit). Within these categories, Davis 
identifies specific interests (p. 44-49):

Table 5.1 / housing interests

\begin{tabular}{|l|l|}
\hline Accommodation & Accumulation \\
\hline $\begin{array}{l}\text { Security } \\
\text { (shelter, safety, stability) }\end{array}$ & $\begin{array}{l}\text { Equity } \\
\text { (market value - debt = equity) }\end{array}$ \\
\hline $\begin{array}{l}\text { Amenity } \\
\text { (quality, size of home; neighborhood } \\
\text { amenities) }\end{array}$ & $\begin{array}{l}\text { Liquidity } \\
\text { (income stream from property) }\end{array}$ \\
\hline $\begin{array}{l}\text { Autonomy } \\
\text { (privacy, freedom of use and control) }\end{array}$ & $\begin{array}{l}\text { Legacy } \\
\text { (pass property to heirs) }\end{array}$ \\
\hline
\end{tabular}

Based upon the distribution of these interests under the existing

commodity housing system, Davis identifies objective interest groups (p. 78):

Table 5.2 / objective housing interest groups

\begin{tabular}{|l|l|}
\hline Accommodation & Accumulation \\
\hline Renters & $\begin{array}{l}\text { Property capitalists } \\
\text { (landlords, financiers, developers) }\end{array}$ \\
\hline Owner-occupiers (homeowners) & Owner-occupiers (homeowners) \\
\hline
\end{tabular}

Objectively speaking, renters should be concerned exclusively with the accommodation/use values of their housing, while also hoping that the exchange value will not increase so as to prevent rent increases. Property capitalists are concerned exclusively with the accumulation/exchange value of property, with the accommodation value being important only because it can be captured as property value. The third group, homeowners, have a more complex relationship with their homes, as they have an objective interest in maximizing both the accommodation and accumulation value. However, these two sets of interests are not themselves in a zero-sum relationship for the homeowner, as the amenity characteristics of the home - which are use values - can be directly 
transformed into an exchange value through the homeowner's equity.

Davis' typology of objective housing interest groups does not include manufactured home owners, who own their homes but must pay rent for a space in a mobile home park. While the Cully Housing Advocacy Survey described in the following chapters attempts to assess the subjective interests of manufactured home owners in Cully (along with renters and homeowners), their objective interests can be theorized to lie mostly on the accommodation side of the typology.

First, as owner-occupiers, manufactured home owners are clearly interested in the use value of their homes. Second, they have a material interest in limiting the exchange value of the land on which their homes sit in order to maintain affordable rents and prevent the closure and redevelopment of the park. Third, the potential exchange value of their homes is inversely related to the exchange value of their landlord's property. To the extent that space rents remain affordable, the resale of a manufactured home in a park should be higher. And finally, any accumulation interest they have in their homes as commodities is limited, relative to traditional homeowners, by the lower value of manufactured homes.

Interest group delineations are complicated by the widespread goal and expectation among renters that they will one day become homeowners themselves. Even while renters' current objective interests in the housing market 
are best served by policies and interventions that remove housing from the market or otherwise limit exchange values, their subjective interests may be influenced by their expectations of one day owning a home.

In this way, the American Dream ideology of homeownership as the prescribed path to household wealth can be a strong impediment to the development of radical housing consciousness for renters, and therefore to the formation of radical housing groups that seek to decommodify housing:

To the extent that mobility to the next rung of the tenure ladder is a realistic - or, at least, a believable - prospect, there is little incentive for 'disadvantaged' interest groups to embrace radical housing goals... because the prospect of transcending one's current property situation makes the possibility of transforming the entire institution of property seem unnecessary and unwise. (Davis, 1991, p. 268-9)

Taking the above considerations into account, I propose a revised breakdown of housing interest groups (Table 5.3):

Table 5.3 / revised housing interest groups, including future aspirations

\begin{tabular}{|l|l|}
\hline Accommodation & Accumulation \\
\hline Renters & $\begin{array}{l}\text { Property capitalists } \\
\text { (landlords, financiers, developers) }\end{array}$ \\
\hline Manufactured home owners & Renters with homeownership goal \\
\hline Owner-occupiers (homeowners) & $\begin{array}{l}\text { Manufactured home owners with } \\
\text { homeownership goal }\end{array}$ \\
\hline
\end{tabular}

The Cully Housing Advocacy Survey, discussed in the following chapters, attempts to distinguish among these groups as they exist in the Cully neighborhood in order to assess not only their objective interests within the housing system, but also their subjective interests, goals and priorities. 


\section{Housing consciousness}

After developing an understanding of the objective housing interest groups that exist in the community, the second task in developing a radical housing movement - again, drawing from Davis (1991) - is to understand how people's subjective, stated housing interests differ from their objective interests. Developing political consciousness means narrowing this gap; it is "the conversion of latent interests into manifest interests" (Davis, 1991, p. 263). This is the work of community organizing - helping people analyze their objective interests, connect their interests with those of their neighbors, and transform objective interests into "interests, subjectively perceived" (Davis, 1991, p. 18).

Urban social movement theory and history demonstrate that movements to gain democratic control of housing are indeed possible, though they rely on certain conditions. I am focused here on the most foundational condition for movement-building: the development of "radical consciousness" (Davis, 1991) about the need for an alternative to the status quo. I do not address other components of movement building, such as organizational development strategy, leadership development or political opportunity structure. Rather, my inquiry centers on residents' potential to view decommodified housing as desirable for themselves and their communities, and then take collective action toward that end. By providing insight into this first precondition for the emergence of a radical housing movement, I hope that my findings will guide 
organizers (including myself) that seek to cultivate a base of urban residents

whose lives would be improved by a radically different housing system.

Social movement theory illuminates the conditions and process by which

radical consciousness comes about - thereby allowing individuals and

communities to question hegemonic ideas and develop alternatives:

1. People must have a baseline ideology or value system about the way things should be (Fainstein \& Fainstein, 1974, ch. 1). In the case of housing, this amounts to a basic belief that all people should have decent, stable housing that they can afford.

2. People must understand that current circumstances do not match up with their vision for how things should be. Crises and unjust circumstances, especially those affecting people themselves or those in their immediate community, can provide a catalyst for this realization (Davis, 1991, p. 265).

3. People must come to understand that the unjust circumstances they witness are not coincidental or the fault of the victims. Unjust outcomes are symptoms of a system that is structurally set-up to produce those outcomes, and therefore the very system should be changed (Davis, 1991, p. 84).

4. People must understand that the unjust system is zero-sum in nature; some groups are structurally positioned to benefit at the expense of others, and this power imbalance must be reconfigured in order to create more just outcomes (Stoecker, 2003, p. 495).

People take action at different stages of consciousness, especially in defense of their own interests. For example, a renter may fight her own eviction without yet believing that all people should have a right to stable, affordable housing. And that renter's homeowner neighbor may act in solidarity to prevent the eviction. Such moments of instability can be openings for the development of consciousness. The first reference point for injustice, after all, is usually 
material and discrete, rather than ideological and systemic. As Piven and Cloward (1977) put it, workers "experience the factory, the speeding rhythm of the assembly line, the foreman, the spies and the guards, the owner and the paycheck. They do not experience monopoly capitalism" (p. 21-2).

Though it is outside the scope of this study to delve into the various practices and tactics of community organizing that might be employed, suffice it to say that the overall endeavor of organizing should be aimed at supporting community members and the groups that they form in progressing through these four stages of consciousness by bringing together people with similar experiences and concerns, and providing a framework for analyzing those experiences that elucidates the structural roots of discrete injustices. From a foundation of shared radical consciousness, residents can engage in collective action by establishing collaborative relationships with one another, identifying a common enemy, and developing a vision for a desired alternative (Barton, 1977). 


\section{Chapter 6}

\section{The Cully Neighborhood Context}

This chapter introduces the Cully neighborhood and why it is an important point of contestation between exchange values and use values, capital and community, and the owners and users of urban space.

Cully has long been an underserved, quasi-peripheral part of Portland. Annexed into Portland in 1985, Cully is located outside the core of Portland's most desirable, historic 'streetcar neighborhoods.' It is a low-density area that follows a predominately suburban development pattern. Many streets are unimproved and lack sidewalks. In a neighborhood of 13,000 residents, there is not a library, post office, community center or senior center. There are no rail transit lines, nor even a direct bus connection to downtown. Industrial land uses and two state highways - rather than the pedestrian-oriented, mixed-use business districts found in Portland's closer-in neighborhoods - dominate Cully's northern and eastern swaths.

As is predictable in a capitalist property market, Cully's lack of Portlandstyle urban services and amenities - combined with its less-than-central location - has allowed it to remain a relatively affordable place for low-income Portlanders to live. Incomes, property values, and rents (along with parks, sidewalks, paved streets, and brewpubs per capita) lag behind the city as a whole. As a corollary to its relative affordability, Cully is home to large minority 
and immigrant populations; by any measure it is one of Oregon's most diverse neighborhoods. As the closer-in neighborhoods of Northeast Portland's Albina district gentrified over the last 25 years, many African American families were displaced and made new homes in Cully.

However, gentrification is now afoot in Cully. The neighborhood seems perched on a precarious precipice, facing a clear and present threat of mass displacement and loss of affordable housing. Property values and rents have been precipitously climbing for the past several years. As both owner-occupied and rented homes appreciate in value beyond the reach of the lower-income families who have long made Cully their home, market-rate affordable housing may become a thing of the past.

Over the past five years, private and public investments have been flowing into Cully. New upscale restaurants and a boutique bike shop have opened. The City, for its part, is focusing planning attention and redevelopment funds in the neighborhood through two "Neighborhood Prosperity" districts. Meanwhile, Living Cully, a coalition of four non-profit organizations, is working to improve the neighborhood with services and amenities to serve people of color and low-income residents. These efforts include commercial and residential development, a 25-acre park, and a variety of social services and advocacy campaigns. Much of this work - motivated as it is by a desire to improve the quality of life for existing residents - will have the effect of increasing property 
values and fueling the fires of gentrification.

These three forces - private investment, public investment, and nonprofit-led community development - are combining with Cully's locational advantages (close to more extensively gentrified neighborhoods, close enough to downtown) and the metro area's strong housing market to make Cully a more desirable place to live for households with greater purchasing power. Much of the neighborhood is made up of large residential lots that are attractive to investors and developers because they can be subdivided or redeveloped at higher densities under existing zoning designations. Consequently, property values are on the rise, and the Portland real estate industry is heavily promoting the neighborhood (e.g. Cordell, 2013).

The situation in Cully fits Neil Smith's (1987) conception of a "rent gap," in which the current uses of real estate generate profit that is increasingly below the level that could be realized through 'higher and better' uses. Because Cully's property has historically been worth less than the Portland average, the rent gap grows as regional property values increase. This provides incentive for capital of all stripes - from banks to developers to real estate investors to homeowners to exploit that gap by purchasing, redeveloping, and/or selling property and housing in the neighborhood.

This is already happening. Apartments are being converted to condominiums - in one case, converted condos were branded as an "eco- 
village" for sustainability-minded urban beekeepers (Sturrock, 2011). Investors are making plays to shut down and redevelop Cully's mobile home parks. Entire apartment buildings are facing de-facto evictions via massive rent increases. In the past 24 months, two instances of threatened mass displacement - one at the Oak Leaf Mobile Home Park and the other at the Normandy Apartments shook the neighborhood. New homes have been sold for over $\$ 700,000$. Trendy bistros and new mixed-use development have spread from the alreadygentrified neighborhoods to the west. Investment of all types is flowing.

As public and private investment, real estate speculation, and new amenities continue driving up property values and rents, it is predictable that Cully will become a less and less affordable place to live. Property and housing will attract speculative investment on the basis of anticipated future exchange values, and low-income households will be unable to compete. Current homeowners are realizing the American Dream of building considerable wealth (i.e. windfall profits) as a result of owning property in a now-desirable neighborhood. Housing can either be affordable or it can be a good investment (Hertz, 2016). Until recently housing in Cully was affordable; now it is increasingly becoming a good investment.

Residents, neighborhood leaders, and even the City of Portland's Bureau of Planning and Sustainability (Bates, 2013) recognize that this dynamic poses an acute threat of direct displacement for people of color and immigrants who 
now call the neighborhood home. In addition, low-income households that might otherwise find housing in Cully in the future will be unable to do so as the neighborhood becomes unaffordable - creating a permanent status quo of exclusionary displacement (Marcuse, 1986; Newman \& Wyly, 2006).

\section{Living Cully's anti-displacement program}

As mentioned earlier, four community development non-profits - Verde, Hacienda Community Development Corporation, the Native American Youth and Family Center (NAYA) and Habitat for Humanity Portland/Metro East - formed the Living Cully collaborative in 2010. The coalition's overarching goal is to catalyze and guide investment and development for the benefit of Cully's existing low-income residents and communities of color - which can only happen if those residents are not displaced as a result of rising housing costs.

Under the banner of Living Cully, these four partners are making transformative community development investments in the neighborhood. In 2015 they purchased and shut down a massive, notorious adult entertainment complex, the Sugar Shack, and are now planning to redevelop the property with affordable apartments (Waldroupe, 2017). In 2018, they completed the yearslong redevelopment of a landfill into a 25-acre park and natural area, creating first-time walking-distance park access for over 500 families (Stewart, 2018).

Recognizing that such investments and amenities contribute to rising property values, yet refusing to accept the catch-22 dynamic of community 
development leading to community displacement, Living Cully launched its antidisplacement efforts in 2013. That year, the coalition commissioned a group of Master of Urban and Regional Planning (MURP) students from Portland State University to conduct research into best practices, along with robust community engagement, and draft a report outlining recommended anti-displacement strategies for the neighborhood. These strategies included land-banking for future affordable housing development, and community organizing to build political power among existing residents.

With the MURP report as a blueprint, Living Cully received foundation funding and in January 2015 hired its first two dedicated, full-time staff people: an outreach and communications coordinator, and a coordinator for the coalition's anti-displacement efforts. The author was hired for the latter role, having already worked with Living Cully as an intern and then on a temporary part-time contract over the course of the preceding year. Living Cully's community organizing around housing issues over the subsequent three years are described in the next chapter. 


\section{Chapter 7}

\section{The Housing Movement in Cully}

This chapter provides an overview of the grassroots affordable housing organizing that has been spearheaded by Living Cully during the period of 20152018 , and then offers five key observations about the state of the neighborhood's current affordable housing movement. This sets the stage for my investigation into the potential for a truly radical housing movement to develop in the neighborhood.

In response to rising housing costs and increased housing instability, many low-income Cully residents, including most prominently those at the Oak Leaf and the Normandy, have mobilized to resist their own displacement. Scores of their neighbors - homeowners, renters and mobile home park residents alike - have taken action in solidarity with residents who faced displacement. In addition, ongoing community organizing being led by Living Cully has engaged hundreds of residents in affordable housing policy campaigns, including the affordable housing bond measure that was approved by Portland voters in November 2016.

\section{Cully Housing Action Team}

Living Cully's grassroots housing organizing began in earnest in the fall of 2015. That October was the first meeting of what would become the the Cully Housing Action Team, or CHAT. Prior to the launch of CHAT, Living Cully's 
community engagement had been focused on specific ad hoc projects, such as the design of the new Cully Park. Living Cully also convened a quarterly invitation-only group called the Living Cully Advisors, made up of neighborhood residents who received reports on Living Cully's activities and provided feedback and guidance. When Living Cully's new staff members brought with them significant community organizing experience, the existing Living Cully Advisors group spun off a new group dedicated to housing issues in the Cully neighborhood: CHAT.

CHAT's first few monthly meetings were focused on education about issues identified as priorities by participants: rising rents, access to affordable units, opportunities for homeownership, and models of community-controlled housing. Guest speakers, discussion groups, door-to-door surveys in the neighborhood, and house meetings were among the first activities organized by CHAT. The group sought to catch up to speed on the housing challenges facing Cully residents and the potential policy solutions that could respond to those challenges, while also doing significant outreach throughout the neighborhood to invite their neighbors to attend the monthly meetings.

\section{Oak Leaf Mobile Home Park}

But before CHAT was ready to proactively launch any policy campaigns, a campaign came to CHAT - and to the entire neighborhood. In January 2016, Living Cully received word that rumors were flying at the Oak Leaf Mobile Home 
Park about a potential sale and closure. It was later confirmed that the long-time absentee owner had agreed to sell the property to a developer who planned to evict the 34 families who lived there and redevelop the property - presumably with much more expensive housing than the $\$ 500$-per-month mobile home spaces that were found at the Oak Leaf. Living Cully joined forces to nearby St. Charles Catholic Church - where many Oak Leaf residents accessed services to respond to the crisis through a community organizing campaign, with Oak Leaf residents in the lead.

While Oak Leaf residents spearheaded the fight to save their homes, the campaign also became the primary focus of CHAT. Activities included demonstrations at City Hall, canvassing and phone calling Cully neighbors to enlist their support, call-in days to City Council, and presentations at churches and other neighborhood-based organizations. On two separate occasions, Cully residents filled an entire school bus to go to City Hall. Oak Leaf residents, CHAT participants and parishioners from St. Charles and other neighborhood faith communities rode the bus together.

The goal was to secure the City's commitment to finance a competing offer from a non-profit to buy the Oak Leaf and preserve it as affordable housing. Meanwhile, Oak Leaf residents worked with Legal Aid attorneys to document myriad legal claims against the existing owner in order to create leverage that could help persuade her to accept the non-profit offer. 
The campaign was ultimately successful. The previous owner decided to accept the non-profit offer to buy the park - rather than face a lawsuit from her tenants - and after many twists and turns St. Vincent de Paul now owns the Oak Leaf and is making major improvements to the property in order to preserve it as permanently affordable housing (Law, 2016).

The Oak Leaf campaign brought dozens of new people into CHAT, and provided immediate evidence that community organizing could win a major victory to preserve affordable homes for very low-income residents in Cully.

\section{Mobile Home Organizing \& Repair Program}

In the midst of the 2016 Oak Leaf campaign, Living Cully and St. Charles Church began applying for grants to fund a dedicated staff person in order to expand our grassroots organizing beyond the Oak Leaf and into the five other mobile home parks in Cully. A emergency-response organizing campaign was ultimately successful at Oak Leaf, but we were concerned that it would not be replicable if another mobile home park were threatened with closure. In addition, our work at the Oak Leaf led to become very concerned about the deteriorated, unhealthy condition of many of the houses in Cully's mobile home parks especially those that are home to older adults, people living with disabilities, and families with young children.

We secured funds to a half-time organizer and launched the Cully Mobile Home Organizing \& Repair Program (aka Cully Mobile Home Program) in early 
2017. The program's approach is to use neighbor-helping-neighbor home repair projects as a community organizing strategy, building relationships and trust among residents as we work together to resolve health, safety and livability issues in each others' homes. In addition to repairing dozens of homes, this program has resulted in increased capacity, leadership, and solidarity among mobile home residents - laying a solid foundation for groundbreaking policy advocacy and the ability for residents to respond to the threatened sale or closure of their parks.

\section{Mobile home zoning campaign}

After the closure and redevelopment of the Oak Leaf Mobile Home Park was narrowly averted in 2016, Living Cully researched policy options that could prevent the closure of Portland's 60 remaining mobile home parks - without requiring the City to step in with millions of dollars each time an owner wanted to sell. We discovered that a number of jurisdictions around the country have preserved their existing manufactured housing stock though the zoning code, by establishing a dedicated zoning designation for that housing type and applying it to existing parks. For the owner or potential redeveloper of a park to use the land for anything other than a mobile home park, they would need to go through a full zone-change process, which creates a high barrier and gives residents and advocates a chance to fight the redevelopment through a transparent public process. 
Albuquerque, NM, has had mobile home zoning in place since the 1970s, and jurisdictions such as Boulder, CO, and - more locally - Tumwater, WA, have followed suit more recently. After an 18-month campaign led by the Cully Mobile Home Program, Portland City Council adopted Oregon's first manufactured housing park zoning designation in August 2018, and applied it to 56 existing mobile home parks, consisting of over 3,000 homes. These properties are now preserved as manufactured housing, and the families who live there have increased stability and much-needed protection from the treat of displacement due to closure and development of their parks.

Mobile home residents from Cully led the charge throughout the zoning campaign: developing demands for the content of the zoning code; meeting with planners and City Council offices; collecting postcards from over 1,000 supporters to deliver to the mayor; canvassing over 20 mobile home parks citywide; giving testimony at the Planning Commission and City Council; and talking with the media, churches, neighborhood associations, and other groups to coordinate their support with the campaign.

\section{Affordable housing bond campaign}

In mid-2016, CHAT participants voted to endorse the $\$ 258$ million affordable housing bond measure that was set to appear on the November 2016 City of Portland ballot, and to get involved in the grassroots campaign to pass it, known as "Yes for Affordable Homes!" Beginning that summer, CHAT organized 
volunteers to talk with voters and distribute flyers at community events in the neighborhood. In the fall, Living Cully secured funding from the Yes for Affordable Homes! campaign in order to provide modest gift card stipends, food and childcare for volunteers who joined a series of eight door-knocking events to encourage voters to support the measure. All told, CHAT participants knocked on over 1,000 doors in Cully in support of the ballot measure, which passed with over $60 \%$ of the vote. In July 2018 , City Council approved bond funds to purchase a parcel in the Cully neighborhood where $50-75$ permanently affordable homes will be built in the coming years.

\section{Normandy Apartments}

In January 2017 another threat of mass displacement shook the Cully neighborhood, this time at the Normandy Apartments. This modest 18-unit complex - at the time home to 18 families of color, the majority of which included immigrants and refugees - is immediately across the street from the Oak Leaf Mobile Home Park, near the western edge of the Cully neighborhood. It is not surprising that these two high-profile mass-displacement threats occurred in this area, as property values are climbing generally from west to east across the neighborhood, and nearby NE $42^{\text {nd }}$ Avenue is home to a newlytrendy business district (Damewood, 2016).

Right around the first of the year, 2017, Normandy residents received a notice that an investor had purchased their building and would be doubling the 
rent, from approximately $\$ 650 /$ month to $\$ 1300$. Living Cully immediately jumped in and began organizing Normandy residents, with invaluable support from the staff and PTA of Rigler Elementary School, where most Normandy families had children enrolled, along with Portland Tenants United, neighborhood churches and other supporters.

CHAT was centrally involved in the Normandy campaign as well, contributing to a public pressure campaign calling on the new owner to rescind the rent increase. For the first time that anyone can remember, a protest march took to the streets of Cully in late February, in support of the Normandy residents' demand for affordable rents. At least 300 people joined the march, which travelled from the Normandy Apartments to Rigler Elementary (Solomon \& Flanigan, 2017).

\section{Renter relocation ordinance}

While the Normandy campaign was ultimately unsuccessful in achieving affordable rents for the former tenants, the landlord did agree to delay the rent increase by three months so that families would not be forced to move until the end of the school year. In addition to this minor concession, the situation at the Normandy - and other similar building-wide evictions and rent increases, such as the Titan Manor apartments in the St. John's neighborhood - brought increased attention and scrutiny to landlord practices in the city.

Tenants at the Normandy and Titan Manor, along with CHAT and other 
tenants' rights groups, played prominent roles in pressuring Portland City Council to adopt an ordinance in February 2017 that requires landlords to pay relocation expenses for tenants who are displaced by a no-cause eviction or large rent increase (VanderHart, 2017). The Normandy families who were displaced from their homes by $100 \%$ rent increases in 2017 were among the first tenants in the city to take advantage of the new relocation assistance ordinance, with each displaced family receiving over $\$ 4,000$ from the landlord.

\section{Tenant opportunity to purchase}

Inspired by the Normandy Apartments situation - in which low-income tenants lost their homes when their previously-affordable apartment building was purchased by a speculative investor - Living Cully and CHAT have been exploring the potential for Portland to adopt a "tenant opportunity to purchase" (TOP) policy, based on a policy that has been in place in Washington, D.C., since the 1980s (Gallaher, 2016). Such a policy would require the owners of rental properties to give 90-days advance notice to their tenants and the City before selling the property, and would give the tenants and City a right-of-firstrefusal to purchase the property. Tenants could assign their purchase rights to a non-profit housing organization to buy the building, or form a non-profit cooperative to buy it themselves. A full-fledged campaign around this policy is on the horizon for CHAT in 2019. 


\section{The state of the housing movement in Cully}

I draw five key conclusions about the 'state of the housing movement' in Cully, based on Living Cully's community organizing over the past three years:

\section{There is a strong foundation of place-based solidarity among Cully residents and organizations, across lines of class, housing tenure and race.}

A good balance of renters, mobile home owners, and traditional home owners has been involved in Living Cully's community organizing. There has been little intra-group conflict based on the opposing objective interests that can be ascribed to these housing tenure groups. Renters and homeowners have played prominent roles in campaigns related to the preservation of mobile home parks. And members of all three interest groups participated enthusiastically in the Normandy Apartments campaign, tenants' rights policies, and the affordable housing ballot measure campaign.

Likewise, solidarity has extended across racial/ethnic divisions - at least in terms of the white and latino residents who are engaged in Living Cully's organizing. (Living Cully's failure to engage other racial and ethnic groups in its organizing is discussed below.) From my perspective as a lead organizer of both campaigns, there was no obvious discrepancy in the level of support in the neighborhood for the preservation of the Oak Leaf Mobile Home Park - a predominantly white property - and the campaign to prevent the displacement of the majority-latino tenants from the Normandy Apartments. Latino renters 
who participate in CHAT are on the front lines of advocacy to support their white neighbors at the Oak Leaf Mobile Home Park; white homeowners lend their time and expertise to lead home repair projects for latino mobile home residents.

A number of neighborhood-based institutions have also supported Living Cully's affordable housing advocacy, in defiance of anticipated divisions along lines of class and housing tenure. Middle-class faith institutions have steadfastly participated in organizing campaigns, and yuppie businesses on NE $42^{\text {nd }}$ Avenue - which stand to benefit if poor renters were displaced and replaced by morewealthy newcomers - raised money to fund the Normandy Apartments antidisplacement campaign. When latino families at the Normandy received the rent increase notice, it was white homeowners in the Rigler Elementary PTA that sounded the alarm and organized the school community to respond.

Perhaps most surprising, the Cully Association of Neighbors (CAN) - part of the City's network of officially-sanctioned neighborhood associations, which are by-and-large dominated by the NIMBY and property-value-defense interests of well-off homeowners (e.g. Ray, 2017) - adopted an "Inclusive Cully Policy" that commits the group to supporting affordable housing and other antidisplacement measures. Based on this policy, CAN has taken positions in support of new affordable housing developments in the neighborhood.

This solidarity across lines of objective interest groups may be rooted both in ideological concerns about equity and inclusion, and in a place-based 
identity that seems particularly strong in the Cully neighborhood. As Davis observes, "People who share a common relation to the place of residence... can and do form solidarities on the basis of interests that are inherent in that relation to that place" (1991, p. 6).

\section{Living Cully's housing organizing base consists almost exclusively of white and latino community members.}

While white English-speakers and latina/o Spanish-speakers are represented in Living Cully's community organizing programs in roughly equal numbers, members of other racial and ethnic groups are conspicuously absent. African-Americans make up about $15 \%$ of the neighborhood's population, which is the third-largest racial/ethnic group after whites and latina/os. Yet AfricanAmericans - along with the significant numbers of Native Americans, Asians and African immigrants who also live in Cully - are, for the most part, not active in Living Cully's grassroots organizing.

These demographic trends are evident to Living Cully staff, and borne out by the self-reported racial and ethnic identities of respondents to the Cully Housing Advocacy Survey, as reported and discussed in chapters 10 and 11 .

\section{Living Cully's housing organizing has been reactive to immediate threats and opportunities, rather than based on a proactive, intentional agenda.}

As described above, at its inception CHAT engaged in a deliberative process of education and discernment about affordable housing issues, which 
was envisioned to lead the group to develop a proactive housing justice agenda. These best-laid plans were short-circuited by the emergency-response campaign to preserve the Oak Leaf Mobile Home Park in 2016. A series of other campaigns followed.

These campaigns have been brought to the group by Living Cully staff, rather than emerging organically from community members themselves. This is not inherently a bad thing; it is certainly an organizer's job to connect the community with opportunities for action, especially when those opportunities are in line with established goals and priorities. However, while CHAT has contributed to important affordable housing victories for Cully and the city of Portland, the group never returned to a process of developing a proactive vision and agenda for what it hopes to achieve, which has left too much of the agenda-setting and direction of the group in the hands of staff.

\section{Living Cully's organizing has focused on taking action, and not on political education or analysis of the root causes of housing injustice.}

The organizing base has been built around concepts of affordable housing and anti-displacement. Participation and calls to action are primarily framed by notions of solidarity and concern for immediate, concrete housing outcomes, such as preventing the loss of homes at the Oak Leaf or winning funds for new affordable housing through the ballot measure campaign. However, little time has been spent on developing activists' understanding and 
analysis of the systemic roots of the injustices that they are organizing around.

Popular education methods could be used to help community members connect their own experiences and those of their neighbors with the dynamics of the underlying political-economic structure, thereby empowering participants to analyze systemic injustice and play a larger role in devising the solutions rather than simply mobilizing in the context of urgent campaigns. This lack of attention to systemic analysis and education further contributes to the lack of a cohesive vision and advocacy agenda, as discussed above.

\section{Organizing has focused primarily on the rental housing sphere.}

Within this focus on rental housing, the structural basis for landlords' profit-maximizing behaviors has been largely unexamined, as described above. Individual landlords, meanwhile, have been depicted as greedy and unscrupulous actors who cause displacement (e.g. Hewitt, 2017).

The injustice inherent in the commodity homeownership system has also been ignored. Homeowners participate earnestly in CHAT and other Living Cully advocacy efforts even as their own property values increase, which will ultimately contribute to the exclusion of even moderate-income households from accessing housing in Cully. While the Yes for Affordable Homes! ballot measure campaign did ask homeowners to pay slightly higher property taxes in order to fund new affordable rental housing, none of Living Cully's housing campaigns have seriously threatened homeowners' profit-making potential - let 
alone explicitly critique the homeownership system.

Homeowners have joined renters to participate in campaigns that threatened the economic interests of an easily vilified, small group of landlords and mobile home park owners. This solidarity across lines of housing tenure, discussed in detail above, has yet to be tested by political education or analysis that exposes the structural injustice inherent in commodity homeownership.

\section{The potential for a radical housing movement in Cully}

Over the past three years, Living Cully's grassroots organizing has succeeded in building a solid base of activists who have contributed to significant affordable housing victories: saving the Oak Leaf Mobile Home Park from closure, Portland's renter relocation ordinance, the city's $\$ 258$ million affordable housing bond, and the citywide manufactured housing park zoning designation. Yet these victories, and the neighborhood's apparent penchant for acting in solidarity across lines of class and housing tenure to respond to displacement threats, will be insufficient to significantly alter the wave of gentrification that is sweeping across the neighborhood.

Critical community development theory and the empirical examples of gentrified neighborhoods around the world - including the closer-in North and Northeast Portland neighborhoods to the west of Cully - teach us that defensive fights to oppose a rent increase over here, or stop the sale of a mobile home park over there, will ultimately fail to shift the overall dynamic of a system that 
produces perpetual crises of housing instability for lower-income people (Marcuse \& Keating, 2006) - with gentrification being a particularly visible and geographically-defined manifestation of mass crisis.

Cully's affordable housing crisis is not unique or even exceptional. It is a microcosm of Portland's affordable housing crisis, and of the national affordable housing crisis, and as such is symptomatic of the same underlying structural causes as the housing crisis writ large:

- Commodified (market-based and under-regulated) rental housing is affordable to lower-income households only until property owners can increase profits by pricing-out or evicting tenants to the next precarious situation, with homelessness being but the most precarious and dangerous of the possibilities.

- Homeownership can sometimes provide stability at the scale of an individual family, but does nothing to make housing affordable or stable for lower-income communities in the long run.

As I have argued, in the face of this dominant market-based housing system, only one solution has been able to preserve and expand a right to housing for lower-income people: decommodification. To achieve measures that in fact limit the commodity nature of housing, especially at a significant scale, requires a strong, radically-oriented housing movement. Tweaks to the existing system will be insufficient to meet the scale of the challenge, and the necessary radical changes won't happen - even at the local scale - without the political power that comes from organized people.

A radically oriented, broad-based, politically powerful housing movement would have the following characteristics: 
- It would grow in numbers through effective outreach and organizing that responds to people's immediate housing needs and concerns (Piven \& Cloward, 1977, p. 21-2);

- It would be broadly representative of and led by people who face housing insecurity - including those in precarious housing tenures, of the mostaffected racial and ethnic groups, across all age ranges and genders;

- It would invite and welcome the solidarity of other individuals and organizations, while maintaining its identity as a movement by and for those who are adversely affected by the status quo housing system;

- It would move from the modes of mobilization and participation to the modes of organizing and movement building;

- It would build radical housing consciousness and shared analysis of structural injustice among its members;

- From that basis, it would develop a proactive agenda for action to decommodify housing - through direct community-ownership of property and through regulations that limit the commodity nature of market-based housing;

- It would form alliances and coalitions with other radically-oriented groups.

The imperative questions for Cully, then, are to what extent such a housing movement is possible and already afoot, and what community organizing strategies and tactics will help it emerge and grow. The Cully Housing Advocacy Survey, which is the described and analyzed in the following chapters, is designed to provide insight into these questions. 


\section{Chapter 8}

\section{Cully Housing Advocacy Survey}

The ultimate goal of my inquiry is to advance the movement for decommodified and community-controlled housing, as a means of securing a right to housing and a right to the city for those who currently lack those rights. In line with Hale's (2001) activist research approach, I seek to support the already-organized housing movement in the Cully neighborhood, spearheaded by Living Cully, by providing insights that will help this movement grow and become more powerful and effective. While my focus is on the potential for a radical housing movement to take root in the Cully neighborhood, my findings have implications beyond that one neighborhood, and speak to the potentials and limitations of neighborhood-based housing advocacy more generally.

My analysis is centrally rooted in the framework of housing consciousness developed by John Davis (1991, ch. 5), which identifies progressive stages of consciousness that individuals and groups progress through as they become radicalized in their belief in a right to housing and understanding of the structural, counter-hegemonic measures that will be required to achieve that right. Building from the foundational premise that the housing system must be radically transformed and decommodified in order to ensure access to housing for all, my research analyzes the extent to which Cully's existing activists already support decommodification and community- 
control of land and housing - as well as the potential for further radicalization. In order to advance this goal, my inquiry explores these questions:

- What degree of critical consciousness about the dominant housing system exists among Cully's existing housing activists? Has involvement in Living Cully's affordable housing organizing groups translated into consciousness of systemic injustice and the need for radical, structural changes to the housing system (Piven \& Cloward, 1977)?

- How do Cully housing activists' subjective interests, priorities and ideologies articulate with their objective housing interest groups and housing histories (Davis, 1991)?

- To what extent do residents prioritize exchange values over use values, and otherwise express adherence to the hegemonic American Dream ideology of commodified housing, including speculative homeownership (Marcuse, 2012)?

- What are the limits of cross-class (cross-housing interest group) solidarity - particularly when it comes to support for zero-sum interventions that explicitly prioritize housing rights (use values) over property rights (exchange values)?

To explore these issues, I engaged directly with the Cully neighborhood's housing activists through a multiple-choice survey conducted in September 2018 (Appendix A). Because my goal is to empirically assess the current 'stateof-the-movement, ' and then from those data provide insights into the movement's potential for the future, participants were limited exclusively to individuals who are already engaged in affordable housing advocacy in Cully, primarily through their participation in two Living Cully programs: the Cully Housing Action Team (CHAT) and the Mobile Home Repair \& Organizing Program (Mobile Home Program, or MHP). Rather than assess the housing consciousness of the general population of the Cully neighborhood, I specifically 
wanted to understand the motivations, interests (objective and subjective), and housing consciousness of individuals who already actively participate in affordable housing advocacy. I wanted to know why they are involved, how they view the housing market and their position within it, and what kinds of interventions and reforms they support.

As described in the subsequent section, my survey is designed specifically to assess respondents' levels of housing consciousness and their objective and subjective interest groups within the housing system. I seek to understand how the distinct housing interest groups within the Cully neighborhood differ in their views, priorities and experiences, and which grassroots organizing strategies and tactics Living Cully should therefore pursue to create a more conscious, radical housing movement. I also hope that my findings provide insights for organizers and critical theorists beyond Cully who are fighting for a right to housing, and more generally for a right to the city.

\section{Participant recruitment}

In order to gather responses from a representative sample of Cully's affordable housing activists, I hoped to recruit a diverse pool of respondents who had been involved in a variety of campaigns and activities over the past three years. This sample would ideally include residents of the Oak Leaf Mobile Home Park and Normandy Apartments; private market renters; tenants living in non-profit-owned housing; participants in a nascent African American organizing 
group supported by Living Cully; and participants in CHAT and the Mobile Home Program.

My professional community organizing experience has taught me that most people - including those who care deeply about an issue, campaign or organization - have many competing demands on their time and attention, and therefore an e-mail announcement or social media post about an event or meeting is often not enough to motivate them to attend. Therefore, in addition to these mass-communication channels, personal relationships and communication - phone calls, text messages, or a knock on someone's door are central to successful community organizing. Drawing upon this knowledge, I planned for my recruitment to include personal communication to follow-up with individuals who might not respond otherwise to an announcement about my survey.

However, Portland State University's Institutional Review Board (IRB) was concerned that my pre-existing relationships with community members, as a community organizer and employee of Living Cully, could place unethical pressure on them to participate in the survey, and asked me to draw a distinction between by role as a community organizer and my role as a researcher. This meant that I was not permitted to recruit people individually to participate, and instead allowed only to announce opportunities to take the survey via mass-communication channels. 
This limitation on my recruitment was significant and unfortunate, as it severely undermined my ability to follow a true activist research methodology. Rather than fully integrating my research with the Cully neighborhood's affordable housing movement and relate to community members as research collaborators, I was asked to treat them solely as anonymous survey respondents, and was prevented from conducting personal outreach to ensure a more diverse and representative sample.

\section{Survey administration}

Despite these limitations on recruitment, the survey was administered at two regularly-scheduled monthly meetings - CHAT on September 4 and the Mobile Home Program on September 20. Through the regular online outreach channels leading up to these meetings (e-mail lists and Facebook posts), the survey was announced as an agenda item for the meetings, along with a mention of $\$ 10$ gift cards for Target stores that were available for respondents. These gift cards were funded by Living Cully.

Per IRB requirements, I was not present in the room at the CHAT and MHP meetings when the survey was administered, in order to avoid any pressure on individuals to respond. At each meeting, I introduced the survey to the group and explained that it was: specifically for people who already participate in some affordable housing advocacy activity, only for individuals age 18 and over, voluntary and anonymous. I also explained that I would leave the 
room and I would not know who had or had not responded, and there would be no personal benefit or negative consequence from participation. Then, after I left the meeting, a pre-recruited volunteer from the group read the survey consent information in English, and an interpreter read a translated Spanish version. The volunteer then distributed the survey and pens, and later collected completed surveys in exchange for gift cards. Most participants spent 20-25 minutes responding to the survey.

An online version of the survey was available for eight days in late September, 2018, so that individuals who had not been able to attend the September meetings would be able to participate. The online survey, which was designed and administered through the Qualtrics platform, was announced through Living Cully's e-mail list and Facebook page. Online respondents did not receive a gift card. 
Chapter 9

Survey Content and Analysis Plan

The Cully Housing Advocacy Survey consists of 45 multiple-choice questions, which fall within the 8 categories outlined below. The survey instrument itself (Appendix A) did not identify these categories nor break the questions up into sections. Appendix B is my internal version of the survey, which divides the survey into the following sections and explains how composite scores were created from multiple questions within each section. Here I discuss each section of the survey and how I planned for it to be used to investigate my research questions:

\section{Screening questions to establish a respondent's age and ensure that they had not previously responded}

\section{Questions about the housing advocacy activities that respondents have participated in, and what motivated their initial involvement}

In addition to helping ensure that all respondents are in fact existing affordable housing activists (a requirement for participation in the survey), these questions explore motivations for first getting involved in housing advocacy. I am specifically interested in discovering how often participation is motivated by personal circumstances (i.e. a struggle to defend one's own housing), as compared with how often it is motivated by solidarity with one's neighbors or by broader social-political concerns. For this reason, Q2.2 asks respondents to prioritize the two most important reasons they first got involved, from a list of six options. I wanted respondents to share the two reasons that most influenced their decision to get involved.

\section{Questions establishing objective housing interest groups}

Using the responses to these questions, I am able to create two different sets of housing interest groups, along the lines of respondents' tenure 
relationship to their homes. First, I divide respondents into three groups: traditional homeowners, mobile home owners, and renters. Then, I add the dimension of future aspirations in order to divide respondents into five interest groups: traditional homeowners, mobile home owners with and without aspirations of becoming traditional homeowners, and renters who do and do not aspire to become homeowners. In each of these sets of interest groups, mobile home renters - those who do not own their own homes, but instead rent a mobile home from the owner of a mobile home park - are analyzed along with the renters, due to their shared material relationship to their housing. Mobile home owners, on the other hand, own their own homes but rent a space in a mobile home park. This is form of tenure and material interest in housing that is distinct from both renters and traditional homeowners, and therefore important to analyze as a separate objective interest group.

The added dimension of future aspiration allows me to explore the possibility that a respondent's housing priorities and consciousness are influenced not only by one's current objective position within the market, but also by the desire to benefit in the future from the privileges of a different tenure arrangement - specifically homeownership.

\section{Questions assessing priorities for a respondent's own housing, with regards to use vs. exchange value}

These three questions can be assessed individually, and also combined into a single composite score used to assess a respondent's relative priority on the exchange values associated with homeownership, as opposed to the use values.

\section{Questions assessing subjective housing ideology and consciousness, broken down into four levels of consciousness}
A. Agreement with the basic ideology that housing is a human right (composite score of 4 questions)
B. Acknowledgement of unjust circumstances in the existing housing system (composite score of 4 questions)
C. Recognition that unjust circumstances result from systemic/structural injustice (composite score of 4 questions)
D. Recognition that structurally-defined groups within the housing system have opposing interests, which are in a zero-sum relationship (composite score of 4 questions)


These four groups of questions allow me to assess the level of housing consciousness of survey respondents, and compare the scores of the objective interest groups established through the questions in section 3. Davis' model suggests the hypothesis that the scores for these composite measures will decrease with each successive level of housing consciousness. There should be greater recognition of unjust housing outcomes, but relatively less understanding of the systemic/structural root causes of housing injustice.

\section{Questions assessing a respondent's support for specific interventions in the housing market}

This section poses a series or "nonreformist reform" interventions in the housing market, each of which in some way limits the commodity nature of housing in order to make housing more accessible, affordable and stable. These interventions include those that either regulate the for-profit market or support the development of more public and non-profit housing, with some aimed specifically at the rental market and others specifically addressing homeownership.

\section{Questions assessing a respondents' history of having benefited from the status quo of the housing market}

These questions provide a simple measure of the degree to which the housing system has privileged individual respondents over the course of their lives (e.g. when the respondent was young, did her family own a home?). Housing consciousness and support for interventions can then be assessed along the lines of this composite variable.

\section{Demographic data}

Along with the data resulting directly from these eight survey sections, and laid out in greater detail in Appendix B, I planned to consider two additional questions. First, I planned to compare respondents' attitudes toward the homeownership system and potential regulations thereof with their equivalent attitudes toward the rental system. Given the dominant ideology that undergirds 
the speculative homeownership system (discussed in chapter two), I hypothesized that respondents would be less critical of and willing to support reforms to homeownership, and more likely to embrace interventions in rental housing. I created composite scores from questions throughout the survey that relate specifically to either homeownership or renting. These composites are outlined in detail at the end of Appendix B.

Second, I planned to note contradictory trends that I observed in the course of data entry and analysis. The survey is designed to examine each concept (e.g. the structural basis for unjust outcomes in the housing market) with a set of questions that approach the concept from different directions; some questions indicate higher levels of housing consciousness via a "strongly agree" response, and others with a "strongly disagree" response. Given this complexity, I anticipated some contradictory responses.

In the next chapter, I report on the data, organized around my research questions. Chapter 11 and the Conclusion analyze these data, and discuss implications for Living Cully's grassroots organizing and future research. 
Chapter 10

Survey Results

This chapter presents the data collected from 104 responses to the Cully Housing Advocacy Survey (Appendix A). Following an overview of respondents' demographic characteristics, data are presented in relation to the research questions that they are designed to respond to. Statistically significant findings are highlighted throughout. The final section of the chapter discusses noteworthy contradictions that emerge from the data. Interpretation of the data presented here is found in the following chapter.

\section{Demographic description of respondents}

Table 10.1/ age groups

\begin{tabular}{|c|c|c|}
\hline Under 18 & $1^{*}$ & $1.0 \%$ \\
\hline $18-34$ & 23 & $22.3 \%$ \\
\hline $35-49$ & 36 & $35.0 \%$ \\
\hline $50-64$ & 27 & $26.2 \%$ \\
\hline 65 and older & 16 & $15.5 \%$ \\
\hline Total & 103 & \\
\hline
\end{tabular}

*The response to the age question on this one survey many have been in error. Respondents were explicitly told that the survey was only for individuals 18 and over, and answers to other questions on this survey call into question that this respondent is actually under 18.

Table 10.2 / survey language

\begin{tabular}{|c|c|c|}
\hline English & 56 & $53.8 \%$ \\
\hline Spanish & 48 & $46.2 \%$ \\
\hline Total & 104 & \\
\hline
\end{tabular}


Table 10.3 / race and ethnicity

\begin{tabular}{|c|c|c|}
\hline Black/African American & 2 & $2.0 \%$ \\
\hline White & 33 & $32.4 \%$ \\
\hline Latino/Hispanic & 54 & $52.9 \%$ \\
\hline Other & 4 & $3.9 \%$ \\
\hline Multiple races & 3 & $2.9 \%$ \\
\hline Prefer not to respond & 6 & $5.9 \%$ \\
\hline Total & 102 & \\
\hline
\end{tabular}

Table 10.4 / gender

\begin{tabular}{|l|l|l|}
\hline Male & 28 & $28.0 \%$ \\
\hline Female & 64 & $64.0 \%$ \\
\hline Non-binary & 3 & $3.0 \%$ \\
\hline Prefer not to respond Total & 100 & $5.0 \%$ \\
\hline & 5 & \\
\hline
\end{tabular}

Table 10.5 / current housing tenure

\begin{tabular}{|c|c|c|}
\hline Homeowner & 27 & $27.8 \%$ \\
\hline Renter & 29 & $29.9 \%$ \\
\hline Mobile home owner & 41 & $42.3 \%$ \\
\hline Total & 97 & \\
\hline
\end{tabular}

Table 10.6 / housing interest group (current tenure + future goal)

\begin{tabular}{|l|l|l|}
\hline Homeowner & 27 & $30.0 \%$ \\
\hline Renter; YES homeowner goal & 15 & $16.7 \%$ \\
\hline Renter; NO homeowner goal & 8 & $8.9 \%$ \\
\hline $\begin{array}{l}\text { Mobile home owner; } \\
\text { YES homeowner goal }\end{array}$ & 6 & $6.7 \%$ \\
\hline $\begin{array}{l}\text { Mobile home owner; } \\
\text { NO homeowner goal }\end{array}$ & 34 & $37.8 \%$ \\
\hline \multicolumn{1}{|c|}{ Total } & 90 & \\
\hline
\end{tabular}




\section{Survey data in response to research questions}

\section{Why have participants become involved in housing advocacy?}

Q2.2 (see Table 10.7 below) asks respondents to identify "the two most important reasons you first got involved in housing advocacy," from among a list of six options, for the purpose of identifying the motivations that most influenced respondents' decisions to get involved, rather than simply selecting all of the reasons that they are involved. This question is designed to provide insight into the balance between participants being motivated by their own personal circumstances and housing struggles, and their concerns for their neighbors and their neighborhood:

- Out of 94 people who both responded to question Q2.2 and indicated their current housing situation in Q3.1, twenty-three selected more than two options for Q2.2, leaving 71 responses from people who followed the instructions to prioritize their top reasons for initially becoming involved by selecting only one or two options. (While selecting only one option is technically not in-line with the question's instructions, it does meet the goal for the question, which is for respondents to prioritize only the most important reasons that they got involved.)

- The 71 valid responses totaled 131 selections, or 1.8 selections per respondent. The numbers of responses for each of three housing tenures are also reported as a percentage of selections made within that group (in bold type in Table 10.7 below).

- "I wanted to support my neighbors" is the most common motivating factor for involvement in housing advocacy (35 selections), followed by "I was worried about the future of my neighborhood" (29 selections) and "I believe the overall housing system needs to be changed" (22 selections).

- Among the three housing tenure groups, mobile home owners were most motivated by self-oriented factors, including threats to their own housing and a desire to learn about their rights; $51.9 \%$ of selections were used for "I was facing a crisis or challenge with my own housing," "I was 
worried that I could face a crisis... in the future," and "I wanted to learn about housing issues and/or my rights." Homeowners (13.5\%) and renters $(30 \%)$ were considerably less motivated by these three factors.

- Both homeowners (37.8\% of their selections) and renters (35\% of their selections) were most motivated to get involved by a desire to support their neighbors.

- Ideological and structural concerns ("I was worried about the future of my neighborhood" and "I believe the overall housing system needs to be changed") provided greater motivation for homeowners (48.6\% of selections) than they did for renters (35\% of selections) or mobile home owners (35.2\% of selections).

Table 10.7 / motivations for initial involvement in housing advocacy (Q2.2)

\begin{tabular}{|c|c|c|c|c|}
\hline & $\begin{array}{l}\text { Homeowners } \\
\text { \# selections } \\
\% \text { selections }\end{array}$ & $\begin{array}{l}\text { Mobile home } \\
\text { owners } \\
\text { \# selections } \\
\text { \% selections }\end{array}$ & $\begin{array}{l}\text { Renters } \\
\text { \# selections } \\
\% \text { selections }\end{array}$ & $\begin{array}{l}\text { TOTAL } \\
\text { \# selections } \\
\% \text { selections }\end{array}$ \\
\hline $\begin{array}{l}\text { I was facing a crisis or challenge } \\
\text { with my own housing. }\end{array}$ & $\begin{array}{l}2 \\
5.4\end{array}$ & $\begin{array}{l}11 \\
20.4\end{array}$ & $\begin{array}{l}6 \\
15\end{array}$ & $\begin{array}{l}19 \\
14.5\end{array}$ \\
\hline $\begin{array}{l}\text { I wanted to support my } \\
\text { neighbors who were facing a } \\
\text { crisis or a challenge with their } \\
\text { housing. }\end{array}$ & $\begin{array}{l}14 \\
37.8\end{array}$ & $\begin{array}{l}7 \\
13.0\end{array}$ & $\begin{array}{l}14 \\
35\end{array}$ & $\begin{array}{l}35 \\
26.7\end{array}$ \\
\hline $\begin{array}{l}\text { I was worried that I could face a } \\
\text { crisis or challenge with my own } \\
\text { housing in the future. }\end{array}$ & $\begin{array}{l}1 \\
2.7\end{array}$ & $\begin{array}{l}11 \\
20.4\end{array}$ & $\begin{array}{l}4 \\
10\end{array}$ & $\begin{array}{l}16 \\
12.2\end{array}$ \\
\hline $\begin{array}{l}\text { I was worried about the future of } \\
\text { my neighborhood. }\end{array}$ & $\begin{array}{l}10 \\
27.0\end{array}$ & $\begin{array}{l}14 \\
25.9\end{array}$ & $\begin{array}{l}5 \\
12.5\end{array}$ & $\begin{array}{l}29 \\
22.1\end{array}$ \\
\hline $\begin{array}{l}\text { I believe the overall housing } \\
\text { system needs to be changed. }\end{array}$ & $\begin{array}{l}8 \\
21.6\end{array}$ & $\begin{array}{l}5 \\
9.3\end{array}$ & $\begin{array}{l}9 \\
22.5\end{array}$ & $\begin{array}{l}22 \\
16.8\end{array}$ \\
\hline $\begin{array}{l}\text { I wanted to learn about housing } \\
\text { issues and/or my rights. }\end{array}$ & $\begin{array}{l}2 \\
5.4\end{array}$ & $\begin{array}{l}6 \\
11.1\end{array}$ & $\begin{array}{l}2 \\
5\end{array}$ & $\begin{array}{l}10 \\
7.6\end{array}$ \\
\hline Totals: & $\begin{array}{l}37 \\
99.9\end{array}$ & $\begin{array}{l}54 \\
100.1\end{array}$ & $\begin{array}{l}40 \\
100\end{array}$ & $\begin{array}{l}131 \\
99.9\end{array}$ \\
\hline
\end{tabular}

What priorities do Cully housing activists have for their own housing? What is the balance between use and exchange values?

This section of three questions asks respondents to prioritize among different components of the "housing bundle," in order to assess the relative 
priority they place on the exchange value and use value components of housing.

Because rental housing does not have an exchange value function, the questions are posed specifically in relation to homeownership, and ask respondents to identify the priorities they have for themselves and their families if they were in the position of looking to purchase a home.

Q4.1 asks respondents to "imagine that you are looking for a new home to buy," and select their top two priorities from among five factors that might influence their home-buying decision. Four of the five choices represent use values (location, condition, size and outdoor areas) and one choice represents exchange values (future value):

- Of the 102 people who attempted to answer this question, 20 selected either 1 option or more than 2 options, leaving 82 valid responses.

- 11 out of 82 respondents (13.4\%) used one of their two selections for "future value." An even distribution would have seen this option selected by 33 respondents (40\%) - three times as many as actually selected it.

- Among the 11 respondents who prioritize "future value," 8 are currently mobile home owners. While mobile home owners account for $43.5 \%$ of respondents to this question, they comprise $72.7 \%$ of respondents who prioritize "future value."

- The most common response by a wide margin was "location" (65 respondents, $79.3 \%$ ), with the other three use value options - condition, size, and outdoor areas - being selected by 32 (39\%), 29 (35.4\%) and 27 respondents (32.8\%), respectively.

Q4.2 asks respondents to select "the two most important advantages of being a homeowner" from a list of five choices. Three of these choices reflect use values: stability, control and privacy, and "give your home to your family" (which is perhaps simply a farther-horizon version of stability). The remaining 
two options represent exchange values: build wealth, and make a profit:

- 100 people attempted to answer this question, with 20 of those selected the wrong number of options. This leaves 80 valid responses, for a total of 160 selections.

- Overall, 23 out of 160 selections went to the two exchange valuefocused options, "build wealth" and "make a profit." In an even distribution, these two options would have been selected a total of 64 times, which is nearly three times as often as they were actually selected.

- 'Build wealth' was selected by 18 out of 80 respondents (22.5\%). Only 5 people selected 'make a profit' (6.3\%). In each case, a hypothetical even distribution would be 32 respondents, or $40 \%$.

- The top two selections were "stability" (63 respondents, $78.8 \%$ ) and "control and privacy" (54 respondents, 68.5\%).

- When considering the five housing interest groups, the two exchange value priorities were the least common selections for all groups other than homeowners. Yet, even for homeowners, the two exchange value priorities combined (10 selections) were selected only one-third as often as the two most common use value priorities (stability=19 selections; control and privacy $=9$ selections).

The Exchange Value Priority Composite is 0-7 scales that combines

questions 4.1, 4.2 and 4.3, with a higher score indicating a higher priority on the exchange value aspects of housing relative to use values. Respondents were only included if they had valid responses to all three questions:

- The mean score among 73 respondents is 0.8 on a scale of 0-7.

- While there are no statistically significant differences among any of the groups analyzed in this survey, it is noteworthy that two housing interest groups - homeowners and mobile home owners with aspirations of becoming traditional homeowners - placed a somewhat higher priority on exchange values than the other groups:

- Renters w/ homeownership goal: .67

- Renters w/o homeownership goal: .71

- Mobile home owners w/o homeownership goal: .75

- Mobile home owners w/ homeownership goal: $\mathbf{1 . 6 0}$ 
○ Homeowners: 1.10

- Similarly, two age groups placed a relatively higher priority on exchange values:

- 18-34: .50

- 35-49: .63

- 50-64: 1.11

○ $65+: \mathbf{1 . 0 8}$

\section{To what extent do people subscribe to the American Dream ideology of speculative homeownership?}

Q3.2 asks "What is your goal for your family's housing in the next 10 years?" The five options are: stay in my current home; move to a rental home; purchase a mobile home/manufactured home/trailer; purchase a house or condominium; and other:

- Overall, $67.7 \%$ of respondents to this question say that their 10 -year goal is to remain in their current home.

- Among the 23 respondents who identify themselves as renters, purchasing a house or condominium is the goal of 15 people $(65.2 \%)$.

- Thirty out of the 40 respondents who identify themselves as mobile home owners (75\%) select "stay in my current home" as their 10 -year goal. Six mobile home owners (15\%) have the goal of purchasing a house or condominium.

- No homeowners or mobile home owners express the goal of becoming a renter. Meanwhile, $30.4 \%$ or renters have the goal of either remaining in their current home $(21.7 \%)$ or moving to a different rental home $(8.7 \%)$.

As discussed above, responses to questions 4.1 and 4.2 indicate an overall low priority on the speculative, exchange value aspects of homeownership. In order to further examine respondents' adherence to the American Dream homeownership ideology, two composite scores were created 
to assess their views about the homeownership vis-a-vis renting, using questions from across several sections of the survey. The Homeownership Composite includes seven questions, with a composite scale of 7.5-34.5. A high score on this scale indicates that the respondent recognizes injustices in the homeownership system and supports interventions:

- The mean score of the 73 respondents who provided valid answers to all seven questions is 26.5 , or $70.4 \%$ of the possible high score (after adjusting for the lowest possible score being 7.5).

The Rental Composite includes six questions, with a composite scale of 6-30. A high score on this scale indicates that the respondent recognizes injustices in the rental housing system and supports interventions:

- The mean score of the 81 respondents who provided valid answers to all six questions is 25.0 , or $79.2 \%$ of the possible high score (after adjusting for the lowest possible score being 6).

These two composite scores indicate that respondents are slightly more critical of, and willing to support interventions in, the rental housing system (mean $=79.2 \%$ of possible high score) than they are the homeownership system (mean $=70.4 \%$ of the possible high score).

\section{What level of housing consciousness do Cully housing activists demonstrate?}

Level 1: A four-question Housing Justice Ideology Composite assesses respondents' belief in housing as a human right (Q5A.1, Q5A.2, Q5A.3, Q5A.4). The range of possible scores on this scale is $4-20$, with a high score indicating 
that a respondent strongly believes in housing as a human right in the abstract, without reference to how that right will be realized:

- The mean score among 87 people with valid responses to all four questions is 16.3 , or $76.9 \%$ of the highest possible score (after adjusting for the lowest possible score being 4). There are no statistically significant differences in composite scores among the various groups identified by the survey (current housing tenure, housing interest group, race, gender, age group, language).

- 83 out of 100 respondents to Q5A.1 - "Housing should be a human right. Everyone deserves a good home at a price they can afford" - selected "strongly agree," and an additional 7 selected "somewhat agree." On a 1-5 scale, the mean score for all respondents is 4.63 , with current renters scoring slightly higher (mean=4.82) than homeowners (mean=4.52) and mobile home owners (mean $=4.58$ ). This difference was not statistically significant.

- Cronbach's alpha test was used to assess the internal correlation of the four questions in this composite. The resulting alpha of .449 reflects a low level of correlation. This results from incongruous responses to Q5A.3 - "Housing should generally be treated as a commodity on the market." After removing that question from the analysis, the remaining three questions have a very strong alpha of .869. Further discussion of Q5A.3 and its effect on the Housing Justice Ideology Composite is provided at the end of this chapter, and in the following chapter.

\section{Level 2: A four-question Unjust Circumstances Composite assesses}

respondents' recognition that the housing market in the Cully neighborhood is producing unjust outcomes for lower-income households (Q5B.1, Q5B.2, Q5B.3, Q5B.4). The range of possible scores on this scale is $4-20$, with a high score indicating that a respondent recognizes the prevalence of unjust housing circumstances for lower-income families in Cully:

- The mean score among 89 people with valid responses to all four questions is 16.1 , or $75.6 \%$ of the highest possible score (after adjusting for the lowest possible score being 4). 
- Differences among groups were insignificant, with the exception of language. People who responded to the survey in English had a higher composite score (mean=16.57) than those who took the Spanish version (mean=14.83). This difference was largely driven by statistically significant differences in the responses to Q5B.1 - which asks if respondents agree with the statement, "In general, the housing market is working well for low-income people in the Cully neighborhood" - and

Q5B.4: "If things don't change, Cully will become a neighborhood where only wealthy people can afford to live." Spanish survey-takers were more likely to agree with 5B.1 (mean=2.95) than English language respondents (mean=3.71), with a higher score indicating disagreement with the statement. Spanish speakers were less likely to agree with 5B.4 (mean=3.49) than English speakers (mean=4.05), with a higher score indicating agreement with the statement.

- Cronbach's alpha test was used to assess the internal correlation among the four questions in this composite. The resulting alpha of .726 reflects a significant correlation.

\section{Level 3: A four-question Systemic Consciousness Composite assesses} respondents' understanding that unjust housing outcomes are structurally determined (Q5C.1, Q5C.2, Q5C.3, Q5C.4). The range of possible scores on this scale is $4-20$, with a high score indicating that a respondent recognizes unjust housing circumstances as symptoms of the underlying housing system:

- The mean score among 79 people with valid responses to all four questions is 14.9 , or $68.1 \%$ of the highest possible score (after adjusting for the lowest possible score being 4). There are no statistically significant differences in composite scores among the various groups assessed in this analysis (current housing tenure, housing interest group, race, gender, age group, language).

- A statistically significant difference based on gender was found in responses to question Q5C.1, "The value of homes is going up in Cully. Overall, this is good for the neighborhood." Those identifying as female disagree with the statement less strongly (mean=3.32) than those identifying as male (mean=3.93). A high score indicates stronger disagreement.

- Cronbach's alpha test was used to assess the internal correlation among 
the four questions in this composite. An alpha of .719 reflects a strong correlation.

Level 4: A four-question Inter-Group Conflict Composite score assesses respondents' recognition that the housing system entails inherent conflict among structurally determined interest groups (Q5D.1, Q5D.2, Q5D.3, Q5D.4).

The range of possible scores on this scale is $4-20$, with a high score indicating that a respondent recognizes the zero-sum nature of interests among groups:

- The mean score among 91 people with valid responses to all four questions is 13.7 , or $60.6 \%$ of the highest possible score (after adjusting for the lowest possible score being 4). There are no statistically significant differences in composite scores among the various groups assessed in this analysis (current housing tenure, housing interest group, race, gender, age group, language).

- A statistically significant difference was found between white and latina/o respondents to Q5D.1, which asks respondents if they agree that, "When property values go up, homeowners benefit at the expense of people who don't own homes." For this question, a higher score indicates stronger agreement with the statement, on a scale of 1-5. Latina/o respondents had a mean of 4.17, and white respondents a mean of 3.42.

- Cronbach's alpha test was used to assess the internal correlation among the four questions in this composite. The resulting alpha of .137 reflects an extremely low level of correlation, which is driven by the responses to Q5D.3, "Rising housing costs hurt everyone." After removing that question from the analysis, the remaining three questions have a strong correlation alpha of .734. Q5D.3 is discussed below.

\section{Do respondents support measures to limit the commodity nature of housing?}

A Support for Interventions Composite score assesses respondents' support for six specific "nonreformist reforms" (Fainstein, 2010; Marcuse, 2012) that would contribute to the decommodification of housing (Q6.1, Q6.2, Q6.3, 
Q6.4, Q6.5, Q6.6). The range of possible scores on this scale is 6.5-29.5, with a high score indicating that a respondent supports interventions in the housing market that would prioritize a right to housing over a right to profit from property ownership.

- The mean score among 85 people with valid responses to all six questions is 23.2 , or $72.4 \%$ of the highest possible score (after adjusting for the lowest possible score being 6.5). The only statistically significant differences in composite scores among the various groups assessed in this analysis (current housing tenure, housing interest group, race, gender, age group, language) was between those who took the survey in Spanish (mean=24.8) and those who took it in English (mean=21.9).

\section{Contradictions emerging from the data}

More than one-in-five respondents (22 out of 96) agree - either strongly or somewhat - both that "in general, the housing market is working well for lowincome people" (Q5B.1) and that "rising rents are causing low-income families in Cully to lose their homes" (Q5B.2).

Shown below in Table 10.8, the average score for Q5D.3, "Rising housing costs hurt everyone," contradicts the scores of the two preceding questions. Respondents who believe that homeowners benefit at the expense of nonowners, and that landlords benefit at the expense of renters, should logically disagree that rising housing costs hurt "everyone," yet that is not borne out by survey responses: 
Table 10.8 / mean scores, section 5D: recognition of inter-group conflict

\begin{tabular}{|l|l|}
\hline & All respondents \\
\hline $\begin{array}{l}\text { Q5D.1: When property values go up, homeowners benefit at the expense of } \\
\text { people who don't own homes. } \\
\text { 1-5 scale, 5=strongly agree }\end{array}$ & 3.81 \\
\hline $\begin{array}{l}\text { Q5D.2: When rents go up, landlords benefit at the expense of renters. } \\
\text { 1-5 scale, 5=strongly agree }\end{array}$ & 4.29 \\
\hline $\begin{array}{l}\text { Q5D.3: Rising housing costs hurt everyone. } \\
\text { 1-5 scale, 5=strongly disagree }\end{array}$ & 1.81 \\
\hline
\end{tabular}

Across all three housing tenures (homeowners, mobile home owners, renters), respondents agree that housing should be treated as a commodity (Q5A.3) at a much higher rate than would be expected based on answers to the other questions in Section 5A. More than one-third of respondents (35 out of 97) either "strongly agree" or "somewhat agree" with both of the seemingly contradictory statements that "housing should generally be treated as a commodity" (Q5A.3) and "housing should generally be treated as a public good" (Q5A.4).

Furthermore, among the three housing tenure groups, homeowners are the least likely to agree that housing should be a commodity, which is in direct contradiction with their objective interests as owners of commodity housing. Table 10.9 shows that the mean score for Q5A.3 is a full point lower than the average of the other three scores in Section 5A for homeowners, and a full two points lower for mobile home owners and renters. This question is discussed further in the next chapter. 
Table 10.9 / mean scores, section 5A: housing justice ideology

\begin{tabular}{|l|l|l|l|l|l|}
\hline & $\begin{array}{l}\text { Q5A.1: } \\
\text { Housing } \\
\text { should be a } \\
\text { human right }\end{array}$ & $\begin{array}{l}\text { Q5A.2: } \\
\text { Lower-income } \\
\text { people } \\
\text { deserve stable } \\
\text { homes } \\
1-5 \text { scale, } \\
5=\text { strongly } \\
\text { agree }\end{array}$ & $\begin{array}{l}\text { Q5A.4: } \\
\text { Housing } \\
\text { should be } \\
\text { treated as a } \\
\text { public good } \\
1-5 \text { scale, } \\
5=\text { strongly } \\
\text { agree }\end{array}$ & $\begin{array}{l}\text { Mean of the } \\
\text { three } \\
\text { means: } \\
\text { Q5A.1, 5A.2, } \\
5 \text { a.4.4 }\end{array}$ & $\begin{array}{l}\text { Q5A.3: Housing } \\
\text { should be } \\
\text { treated as a } \\
\text { commodity }\end{array}$ \\
\hline Homeowners & 4.52 & 4.54 & 4.25 & 4.44 & $\begin{array}{l}1-5 \text { scale, } \\
5=\text { strongly } \\
\text { disagree }\end{array}$ \\
\hline Renters & 4.82 & 4.76 & 4.61 & 4.73 & 2.72 \\
\hline MH owners & 4.58 & 4.44 & 4.11 & 4.38 & 2.39 \\
\hline Total & 4.63 & 4.56 & 4.30 & 4.52 & 2.77 \\
\hline
\end{tabular}




\section{Chapter 11}

\section{Survey Analysis}

In this chapter I analyze the data reported in the preceding chapter and offer critiques and suggestions for Living Cully's community organizing in order to build a more diverse, conscious and ultimately powerful housing movement.

\section{Survey participation}

In many ways the community members who participated in the Cully Housing Advocacy Survey are a diverse group that is accurately representative of the universe of people who currently participate in Living Cully-led housing advocacy. However, this group of survey respondents also reflects the shortcomings of Living Cully's community organizing, in terms of the demographic and cultural groups that are alarmingly absent from both the survey and the housing advocacy programs from which survey respondents were recruited. Demographic data from the survey is found in chapter 10.

\section{Race and ethnicity}

As discussed in chapter eight, I believe that a more robust, communityengaged recruitment effort could have resulted in a larger and somewhat morerepresentative survey sample. For example, approximately ten African American community members have been engaged over the last nine months in a nascent group that is focusing specifically on outreach and advocacy within Cully's black 
community, with organizational support from Living Cully. It is likely that the extremely low number of African American survey respondents (two) is partly due to the IRB restrictions that prevented personal communication with these individuals to recruit them as survey participants and explain how the survey is integrated with Living Cully's advocacy efforts.

However, the more central reason for the low number of African American respondents is that Living Cully has largely failed to engage African Americans who make up roughly $15 \%$ of Cully's population - in its community organizing programs. This glaring shortcoming led to the launch of Living Cully's African American organizing group in early 2018 , and these survey data lend even great urgency to the need for Living Cully to focus resources and time to that effort.

Other racial and ethnic groups are also absent from Cully's community organizing and the pool of survey respondents, despite there being significant populations of these groups in Cully. There are zero survey respondents who identify as African, Asian, Native American or Pacific Islander alone, and only three respondents who identify with one of these groups in addition to white.

\section{Language}

The division between respondents who took the survey in English (53.8\%) and Spanish (46.2\%) seems generally representative of participation in Living Cully's community organizing groups, which are intentionally and overtly a bilingual and bicultural. Other major language groups in the Cully neighborhood 
include Somali and Vietnamese, and Living Cully has made only extremely limited efforts to engage speakers of those languages.

\section{Gender}

The sample of survey respondents is heavily skewed toward people who identify as female ( $61.5 \%$ of the sample), while male respondents account for only $26.9 \%$. While Living Cully has not yet compiled comprehensive demographic data on its community organizing base, my experience as an organizer with Living Cully over the last three years tells me that this gender distribution seems to approximately reflect the gender make-up of program participants.

This gender imbalance is not surprising. Scholars have noted the historic prominence of women in urban social movements, and particularly those focused on housing (Marcuse, 1999). In The City and the Grassroots, Castells (1983) notes that grassroots urban struggles are often about the systems - such as housing - that shape everyday life in the city. Because men have historically ceded civil society roles to women in favor of a focus on politics, religion, production and war, women have risen to positions of leadership in "the struggle for a better, or even an alternative, form of life" (p. 68).

While Castells' analysis precariously positions women as leaders of urban movements only when men have ceded their (presumably natural) role as leaders, other scholars theorize women's involvement and leadership in terms of 
the very content of the organizing that they choose to engage in:

"Indeed, anyone who has practiced organizing or planning at the neighborhood level for any length of time has probably discovered that women make up the majority of most locality-based organizations that promote accommodative interests and ideas... Interests, ideas, and relationships that define the place of residence as 'community,' rather than 'commodity,' tend to spark the political mobilization of women, when threatened, more often then they spur the mobilization of men." (Davis, 1991, p. 318)

In addition, those whose time and energies are most focused on social reproduction are facilitated in their involvement in community organizations when those organizations "can ease their social reproduction burden" by "providing social reproduction services through the movement[, which] removes barriers to involvement and provides incentives to become involved" (Stoecker, 1994, p. 218). Living Cully's community organizing programs provide meals, childcare, home repairs, occasional opportunities for compensated volunteer work (e.g. gift cards to grocery or variety stores for people who participate in canvassing and other outreach efforts), and access to a network of communitybased support and solidarity.

Age

Based on my experience as a community organizer with Living Cully over the last three years, the age distribution of respondents seems to reflect the distribution of participants in Living Cully's housing advocacy programs. All four age groups are well represented, with between $15 \%$ and $35 \%$ of respondents 
falling in each group. While those under the age of 18 were not invited to participate in the Cully Housing Advocacy Survey, the Cully Housing Action Team (CHAT) has noted a lack of young people involved in the group, and early this year launched an effort to increase its engagement with the next generation of housing activists. Meanwhile, the involvement and leadership of older adults in Living Cully's organizing is a strong point that has contributed greatly to successful anti-displacement and affordable housing policy campaigns.

\section{Housing tenure and housing interest group}

Participants in the survey reflect a good distribution among the three dominant housing tenures in the Cully neighborhood: homeowners (26.0\%), renters (27.9\%) and mobile home owners (39.4\%). The largest group of respondents is mobile home owners (41 respondents), which largely reflects their participation in Living Cully's Mobile Home Organizing \& Repair Program. The other recruitment pool for the survey was the Cully Housing Action Team (CHAT), which counts members of all three tenure groups among its regular participants.

Within the renter category, respondents were asked to identify if their landlord was a for-profit entity or a public/non-profit entity. Given the fact that Hacienda Community Development Corporation owns over 300 regulated rental units in the Cully neighborhood, it is somewhat surprising that only five of the 29 renters indicated that they "rent from a public or non-profit landlord (example: 
Hacienda CDC)." The four individuals who selected the option "I rent a mobile home/trailer from the landlord" - which is a distinct response from those who own their own mobile homes and rent a space - are categorized as renters for purposes of data analysis, rather than mobile home owners, given that their material/economic relationship to their homes is identical to that of more traditional renters. It should be noted, however, that the use value and community-related aspects of renting a mobile home are likely more akin to mobile home owners than they are to those who rent an apartment.

For their part, as discussed in chapter four, mobile home owners have a complicated material relationship with residential property. Davis' (1991) model of "domestic property interest groups" does not address mobile home owners, who own the physical structures of their homes but rent the land that their homes sit on. Davis identifies traditional homeowners as having both accommodation (use value) and accumulation (exchange value) interests in housing because they use the home for housing, but also have a stake in its commodity value - which, first and foremost in terms of interest group formation, includes the commodity value of the land.

Mobile home owners, on the other hand, have smaller accumulative stakes in their homes due to the inherently lower value of manufactured housing, and because mobile home owners do not own land and should therefore objectively support its decommodification - or any measure that would keep 
space rents in check. In fact, because the actual cost of owning a manufactured home includes both the acquisition cost and the monthly space rent, the market value of the home should increase if the land it sits on is protected from market forces. Traditional homeowners, of course, benefit from rising property values and their objective interests should lead them to oppose measures that limit the commodity nature of land. While mobile home owners' objective interests can certainly be analyzed within Davis' model of housing interest groups, the existing literature has not included this group even at the theoretical level much less tested the subjective interests of mobile home owners themselves against a theorized set of objective interests.

In addition to asking respondents to identify their current housing situation (Q3.1), the survey asks them to identify their primary goal for their family's housing for the next ten years (Q3.2). Responses to these two questions were combined to create five housing interest groups (see Table 10.5), based on respondents' material relationships to their current homes and the additional dimension of their hoped-for future position within the housing market. In his model of of housing interest groups, Davis (1991) discusses the likelihood that current renters' subjective interests may be influenced by their hope or expectation of becoming homeowners in the future, which could explain a potential discrepancy between their' objective interests given their existing position within the market and their subjective interest in maintaining a status 
quo system that prioritizes wealth-accumulation for property owners over affordable housing for all.

By creating housing interest group categories that include future homeownership aspirations, I attempted to test for this effect - respondents' current housing tenure and their housing interest group were used throughout data analysis to explore for differences in subjective interests and priorities. Ultimately, however, the five-category housing interest group variable did not produce a statistically significant difference for any of the measures of subjective housing interests that were analyzed by this survey. The threecategory variable for current housing tenure, on the other hand, did result in a few statistically significant results, which are noted in the following sections. This indicates that a renter's or mobile home owner's desire to enter into traditional homeownership in the future does not significantly influence subjective housing interests, but - in some cases - current housing tenure does.

\section{Housing consciousness}

As discussed in chapter five, John Emmeus Davis develops a comprehensive framework for housing consciousness and interest group formation in his 1991 book, Contested Ground: Collective Action and the Urban Neighborhood. I have adapted his model in order to assess the housing consciousness and subjective interests of the Cully neighborhood's existing affordable housing activists. This adapted model identifies four stages of 
housing consciousness that individual activists - and the housing advocacy

groups they form - might exhibit in the process of organizing for radical changes

to the existing housing system.

Each of the four stages is assessed by the Cully Housing Advocacy

Survey with a composite score made up of four questions related to that

specific stage of housing consciousness. Each composite score is on a 4-20

scale. As the model would predict, the mean score decreases with each

successive stage of consciousness, from 16.3 for stage one to 13.7 for stage

four (Table 11.1, Chart 11.1):

Table 11.1 / composite scores for stages of housing consciousness

\begin{tabular}{|l|l|l|l|l|}
\hline & $\begin{array}{l}\text { 1. Housing } \\
\text { justice ideology } \\
\text { Respondent } \\
\text { believes in a right } \\
\text { to housing in the } \\
\text { abstract, without } \\
\text { reference to how } \\
\text { that right will be } \\
\text { realized. }\end{array}$ & $\begin{array}{l}\text { 2. Recognition of } \\
\text { unjust } \\
\text { circumstances } \\
\text { Respondent } \\
\text { recognizes the } \\
\text { prevalence of } \\
\text { unjust housing } \\
\text { outcomes. }\end{array}$ & $\begin{array}{l}\text { 3. Recognition of } \\
\text { unjust system } \\
\text { Respondent } \\
\text { recognizes unjust } \\
\text { circumstances as } \\
\text { symptoms of } \\
\text { unjust system. }\end{array}$ & $\begin{array}{l}\text { 4. Recognition of } \\
\text { inter-group } \\
\text { conflict } \\
\text { Respondent } \\
\text { acknowledges } \\
\text { zero-sum nature of } \\
\text { housing interests } \\
\text { between groups } \\
\text { 4-20 scale }\end{array}$ \\
\hline Renters & $\begin{array}{l}17.0 \\
27 \text { valid responses }\end{array}$ & $\begin{array}{l}16.1 \\
28 \text { valid responses }\end{array}$ & $\begin{array}{l}15.8 \\
24 \text { valid responses }\end{array}$ & $\begin{array}{l}13.7 \\
29 \text { valid responses }\end{array}$ \\
\hline $\begin{array}{l}\text { Mobile home } \\
\text { owners }\end{array}$ & $\begin{array}{l}15.4 \\
37 \text { valid responses }\end{array}$ & $\begin{array}{l}15.5 \\
36 \text { valid responses }\end{array}$ & $\begin{array}{l}14.3 \\
35 \text { valid responses }\end{array}$ & $\begin{array}{l}13.4 \\
36 \text { valid responses }\end{array}$ \\
\hline Homeowners & $\begin{array}{l}17.0 \\
23 \text { valid responses }\end{array}$ & $\begin{array}{l}17.0 \\
25 \text { valid responses }\end{array}$ & $\begin{array}{l}14.8 \\
20 \text { valid responses }\end{array}$ & $\begin{array}{l}14.0 \\
26 \text { valid responses }\end{array}$ \\
\hline $\begin{array}{l}\text { All } \\
\text { respondents }\end{array}$ & $\begin{array}{l}16.3 \\
87 \text { valid responses }\end{array}$ & $\begin{array}{l}16.1 \\
89 \text { valid responses }\end{array}$ & $\begin{array}{l}14.9 \\
79 \text { valid responses }\end{array}$ & $\begin{array}{l}13.7 \\
91 \text { valid responses }\end{array}$ \\
\hline
\end{tabular}


Figure 11.1 / composite scores for stages of housing consciousness

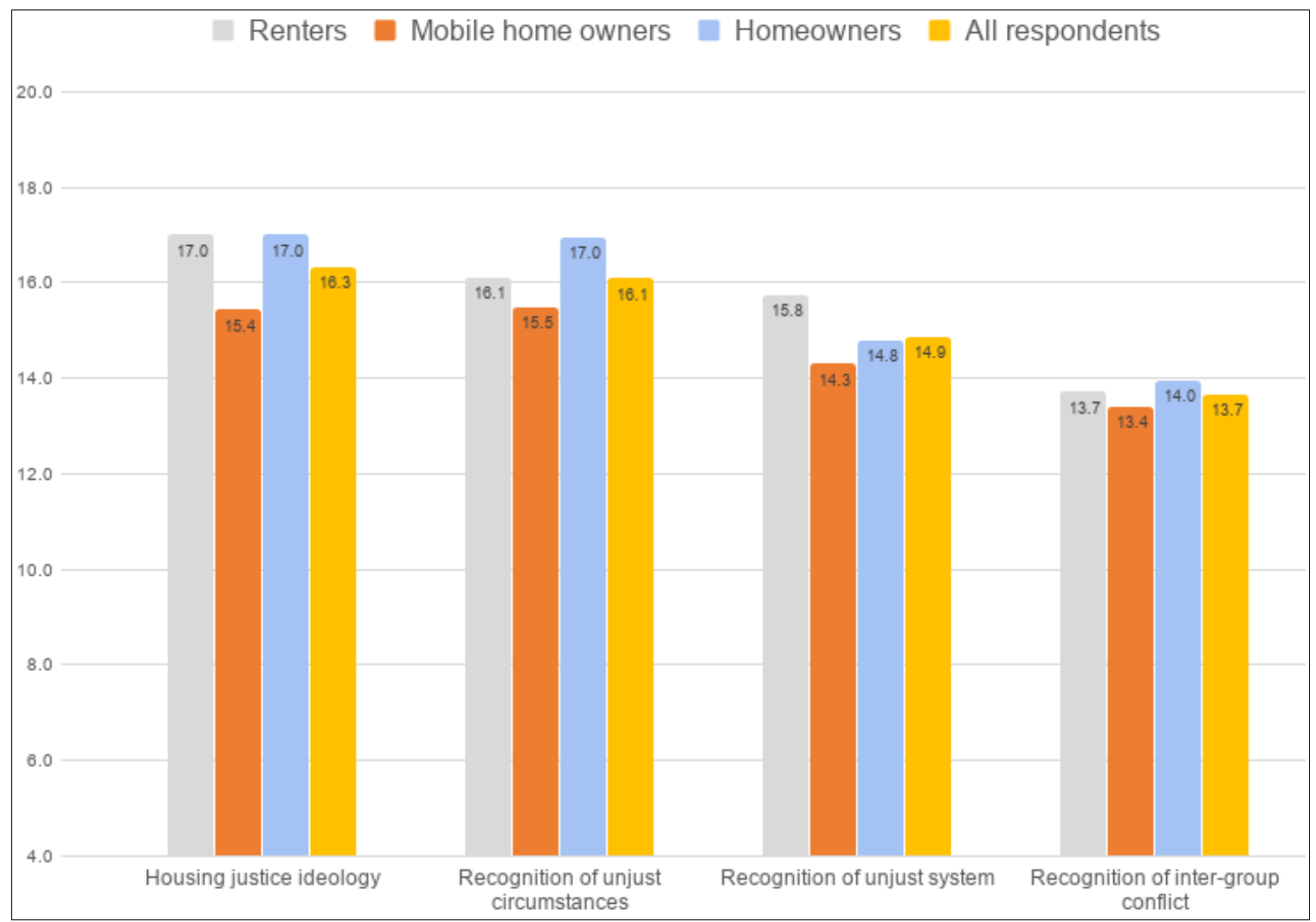

\section{Housing justice ideology $=16.3$}

The first stage of housing consciousness is a basic ideological belief that people should have decent, affordable housing, and that something is wrong if they don't. Therefore, a mean score of 16.3 is not surprising for this stage, given that the survey respondents are all currently engaged in affordable housing advocacy in the Cully neighborhood. This score indicates general agreement among participants in Living Cully's grassroots organizing programs that housing should be a human right, and that lower-income people deserve to have stable, affordable homes in Cully.

There is reason to believe that this score would be even higher if not for 
the contradictory, surprisingly low responses given to question 5A.3 ("Housing should generally be treated as a commodity on the market"), as discussed at the end of chapter 10. More than one-third of respondents (35 out of 97) either "strongly agree" or "somewhat agree" with both 5A.3 and the following, seemingly contradictory 5A.4, which states that "housing should generally be treated as a public good" (Q5A.4). There are at least four potential and partial explanations for the unusually low scores for this question:

1. Q5A.3 is a reverse-coded question, meaning that an answer of "strongly agree" results in a low score, rather than a high score. To demonstrate adherence to a belief in housing as a human right, and therefore receive a higher score, a respondent should strongly disagree with the statement that housing should generally be treated as a commodity. The other questions in this section of the survey were standard-coded (5=strongly agree), which may have caused confusion for some respondents.

2. The concept of "commodity" may have been misunderstood by some respondents.

3. The only statistically significant difference among any groups with respect to this question was based on current housing tenure. Mobile home owners, which make up the largest housing tenure group in the sample, had the lower score. This may result from a desire to assert that their homes are in fact commodities and valuable assets for their families. However, this explanation would not account for the similarly low mean score for renters, nor the fact that homeowners had the highest mean score among the three groups, despite the fact that their objective interests as owners of commodity housing should lead them to have the lowest score.

4. Across all housing groups, many respondents truly believe that, while housing should be a human right and public good, it should also remain a market commodity in some respect.

As a result of the anomalous responses to Q5A.3, this four-question composite has a low level of internal statistical correlation. Cronbach's alpha 
test was conducted for the four questions, resulting in an alpha of .449.

However, after removing Q5A.3 from the analysis, the resulting alpha for the three remaining questions (Q5A.1, 5A.2, 5A.4) is .869.

\section{Recognition of unjust circumstances $=16.1$}

If the first stage of housing consciousness is a belief in the way that things should be, stage two is a basic recognition that, in reality, things are not as they should be. This four-question composite finds strong agreement among respondents that lower-income people are facing unjust housing outcomes. The mean score of 16.1 is, as predicted by the theoretical model, slightly lower than the stage one score.

The propensity for Spanish speakers to be somewhat more optimistic about the housing market and the future of the neighborhood than English speakers could be the result of a faith in the power of community organizing to preserve affordable housing, and a recognition that the neighborhood currently has an above-average share of regulated affordable homes, thanks largely to Hacienda CDC. Or, it could be a sign of the need for Living Cully's organizing to include more effective popular education about the true nature of the housing crisis that lower-income people are facing.

\section{Recognition of unjust system $=14.9$}

The third stage of housing consciousness is the step from acknowledging 
that things are not as they should be to understanding that unjust circumstances are not, in fact, circumstantial. In order for individuals and groups to work toward systemic solutions, unjust outcomes must be seen as symptoms of an underlying, unjust system. The inability of a lower-income family to afford a rent increase must be understood as a structural problem, rather than circumstantial.

The composite score for this stage of consciousness is lower than that for the first two stages, which is congruent with the hypothesis. There are no statistically significant differences among groups.

\section{Recognition of inter-group conflict $=13.7$}

The final stage of consciousness in this adapted model is a recognition that the unjust system produces unjust outcomes specifically by creating benefits for some at the expense of others. Landlords benefit at the expense of renters; homeowners benefit at the expense of homebuyers; speculators at the expense of people in need of affordable homes; gentrifiers at the expense of the displaced. In short, the housing system is a zero-sum system: in order for outcomes to be more just, the balance of power and privilege must change.

Not surprisingly, this final stage has the lowest composite score. Consciousness of inter-group conflict inherently entails a challenge to the status quo, and the consideration of measures that would limit or take away some "rights" as they are currently understood (namely, the right to profit from property ownership). This stage of consciousness opens the door for radical, 
structural solutions, and implies confrontational, contentious forms of community organizing.

No statistically significant differences were found among groups with respect to the entire composite, but latina/o respondents (mean=4.2) had a significantly higher score than white respondents (mean=3.4) to Q5D.1. This question asks for agreement with the statement, "When property values go up, homeowners benefit at the expense of people who don't own homes." In other words, rising property values are not only a sign of an unjust system, but a demonstration that one housing interest group is deprived of stability and wealth precisely because another group is structurally positioned to benefit.

\section{Adherence to dominant housing ideology}

Peter Marcuse (2012) lays out a tripartite U.S. national housing ideology, consisting of: 1) the provision of housing as a speculative, market-based commodity; 2) a limited state role in regulating and intervening in the private housing market; and 3) private homeownership as the fulfillment of a hegemonic psycho-social-political American Dream ideology. Data collected in the Cully Housing Advocacy Survey speak to all three of these pillars, and suggest that Cully's housing activists are, at the least, skeptical of this housing ideology and ready to support measures that would limit the commodity nature of housing.

With relation to the first pillar, the commodification of housing writ large, survey respondents overwhelming agree, in the abstract, that "housing should 
be a human right" (mean=4.6 on a 1-5 scale) and that "housing should generally be treated as a public good" (mean=4.3 on a 1-5 scale). And despite what I suspect to be substantial misunderstanding of Q5A.3 (discussed above), respondents only very slightly agreed that "housing should generally be treated as a commodity on the market" (mean=2.8 on a $5-1$ scale).

Other responses reinforce the conclusion that Cully's housing advocacy base is poised to embrace the decommodification of housing, especially in conjunction with a well-designed political education and consciousness-raising strategy. For example, in Q6.1, respondents were more likely than not to agree that "more housing should be owned by the government and non-profit organizations, instead of by families and companies" (mean=3.5 on a 1-5 scale). They were even more prone to agree, in Q6.3, that "there should be new laws to limit how much a homeowner can sell their home for" (mean=3.7 on a 1-5 scale). Incredibly, there was not a statistically significant difference in responses to Q6.3 between homeowners and renters - though Spanish speakers (mean=4.4) were significantly more likely to agree with the statement than were English speakers (mean=3.2).

The second pillar of Marcuse's three-part housing ideology, a limited role for the state in providing public housing and regulating market-based housing, is also on precarious footing with Cully housing activists. As noted above, respondents support the notion that housing should be a public good, and that 
more housing should be owned by the public and non-profit sectors.

Furthermore, the mean score for a composite assessing support for six potential public sector interventions in the housing market is 23.2 on a scale of $6.5-29.5$, or $72.4 \%$ of the highest possible score.

Survey respondents are also hesitant to fully embrace the third pillar of Marcuse's housing ideology, which is private-market homeownership as a fulfillment of the American Dream. While a clear majority of renters $(65.2 \%)$ hold the 10-year goal of purchasing a home, a larger majority of mobile home owners (75.0\%) simply want to remain in their current homes. Across all categories of survey respondents, including renters who hope to own homes in the future, use values (stability, privacy) were selected far more often than exchange values (build wealth, make a profit) when respondents were asked to prioritize the most important advantages of homeownership.

Furthermore, a plurality of respondents, $44.3 \%$, responded in Q6.6 that the their preferred homeownership system for the Cully neighborhood would be one in which "it is more affordable to buy a home, because homeowners cannot make a profit when they sell." Only $19.3 \%$ prefer the status quo homeownership system, "It is more expensive to buy a home, because homeowners can make a profit when they sell," and $36.4 \%$ had no preference between the two. 


\section{Support for interventions}

Survey respondents indicated support for each of six hypothetical

interventions in the housing market. (Tables 11.2 and 11.3). If enacted, each of these reforms would contribute substantially to limiting the commodity nature of housing by prioritizing the right to be housing over the right to profit from the commodity of housing:

\section{Table 11.2 / support for housing market interventions}

\begin{tabular}{|l|l|l|l|l|}
\hline \% responding "somewhat agree" or "strongly agree" --> & Renters & $\begin{array}{l}\text { Mobile } \\
\text { home } \\
\text { owners }\end{array}$ & $\begin{array}{l}\text { Home- } \\
\text { owners }\end{array}$ & Total \\
\hline $\begin{array}{l}\text { Q6.1: More housing should be owned by the government } \\
\text { and non-profit organizations, instead of by families and } \\
\text { companies. }\end{array}$ & $48.3 \%$ & $55.0 \%$ & $55.6 \%$ & $53.1 \%$ \\
\hline Q6.2: There should be new laws to limit rent increases. & $86.2 \%$ & $90.0 \%$ & $77.8 \%$ & $85.4 \%$ \\
\hline $\begin{array}{l}\text { Q6.3: } \text { There should be new laws to limit how much a } \\
\text { homeowner can sell their home for. }\end{array}$ & $58.6 \%$ & $62.5 \%$ & $50.0 \%$ & $57.9 \%$ \\
\hline $\begin{array}{l}\text { Q6.4: Homeowners who make a profit by selling their } \\
\text { homes should pay higher taxes, in order to create funds } \\
\text { for affordable housing. }\end{array}$ & $58.6 \%$ & $62.5 \%$ & $52.0 \%$ & $58.5 \%$ \\
\hline $\begin{array}{l}\text { Q6.5: Landlords who make a profit by selling an } \\
\text { apartment building or raising the rent should pay higher } \\
\text { taxes, in order to create funds for affordable housing. }\end{array}$ & $86.2 \%$ & $70.0 \%$ & $76.9 \%$ & $76.8 \%$ \\
\hline
\end{tabular}

\section{Table 11.3 / Q6.6}

Q6.6: In a perfect world, which of these two systems for homeownership would be best for the Cully neighborhood?

It is more affordable to buy a home, because homeowners cannot make a profit when they sell.

It is more expensive to buy a home, because homeowners can make a profit when they sell.

I have no preference.

\begin{tabular}{|l|l|l|l|}
\hline Renters & $\begin{array}{l}\text { Mobile } \\
\text { home } \\
\text { owners }\end{array}$ & $\begin{array}{l}\text { Home- } \\
\text { owners }\end{array}$ & Total \\
\hline $46.2 \%$ & $48.6 \%$ & $39.1 \%$ & $45.2 \%$ \\
\hline $7.7 \%$ & $20.0 \%$ & $26.1 \%$ & $17.9 \%$ \\
\hline $46.2 \%$ & $31.4 \%$ & $34.8 \%$ & $36.9 \%$ \\
\hline
\end{tabular}

While respondents tend to agree with all six of these measures, there is 
clearly more reluctance to intervene in the homeownership system (Q6.2, 6.3, 6.6) than in the rental market $(Q 6.2,6.5)$. This finding adds credence to theoretical assertions of the hegemonic resonance of the American Dream homeownership goal (discussed in chapter 2), as even committed housing activists who support a variety of radical interventions in the housing market are noticeably less enthusiastic in their support for regulations that challenge the profit-making potential of owning a private home.

A more surprising finding is the comparatively low level of agreement with Q6.1, which proposes that more housing be owned by non-profits and the public sector (Q6.1). This question had the lowest level of agreement among the six proposed interventions, perhaps indicating a desire for housing to remain market-based but more strictly regulated - which would corroborate responses to Q5A.3, in which respondents slightly agree on average that housing should generally be treated as a market commodity.

Particularly unexpected is that renters were least likely support this intervention (48.3\% either somewhat agree or strongly agree), even though renters should have the most to gain from the decommodification of rental housing. A potential explanation could be latent support for models of community-controlled housing - such as cooperatives and land trusts - in which residents have a non-speculative, non-profit-seeking, democratically organized ownership stake in their homes. 


\section{Conclusion}

\section{Implications for Organizing and Future Research}

To make sense of the findings of the Cully Housing Advocacy Survey, I return to the five research questions that are posed in the introduction to this paper, and reflect on the implications of the survey data for community organizing practice. I then offer thoughts on the limitations of this study, and how future research could provide additional insights.

\section{Responding to the research questions}

\section{Why are people involved in housing advocacy?}

As discussed in chapter 10, current activists are more strongly motivated by a desire to support their neighbors than they are by concerns about their own housing situations. This is especially true for homeowners. While this bodes well for inter-group solidarity, it also indicates that Living Cully should focus its outreach and organizing on community members who are themselves facing the most serious threats to their housing, including mobile home residents and tenants living in market-based rentals.

\section{Do activists subscribe to hegemonic notions of homeownership?}

Survey responses demonstrate widespread skepticism of homeownership as a speculative wealth-building scheme. Respondents overwhelmingly 
prioritized the use value aspects of homeownership over exchange values, and a plurality explicitly stated their preference for limiting the wealth-building potential of homeownership in order to preserve affordability. However, respondents were less supportive of interventions in the homeownership market than of similar interventions in the rental market.

Living Cully's community organizing should emphasize political education and analysis that brings to light the role of the commodity homeownership system in contributing to gentrification and inequitable access to housing. Future research could include qualitative methods such as interviews and focus groups to explore motivations for homeownership in greater nuance.

\section{To what extent have Cully's housing activists developed radical housing consciousness that leads them to see unjust housing outcomes as symptoms of an unjust system?}

With reference to the four-level scale of housing consciousness, survey data indicate that respondents overwhelmingly agree that housing should be a human right (level 1) and acknowledge widespread unjust outcomes in the existing housing system (level 2). Understanding of housing injustice as a systemic problem (level 3) is somewhat less strong, as is recognition of the zerosum nature of the relationships among housing interest groups (level 4).

It is recommended that Living Cully seek out or develop popular education curricula and methods that can facilitate consciousness-building in 
these areas, and incorporate political education and analysis as an ongoing, indispensable practice in its community organizing. A follow-up survey administered in the future could assess the effectiveness of such efforts.

\section{What measures to decommodify housing do Cully's housing activists already support?}

First, the very concept of "commodity" does not appear to be wellunderstood by survey respondents (as discussed in chapter 10). Nonetheless, survey data indicate strong support for measures to regulate the rental market, such as rent control, and comparatively weaker support for measures to regulate homeownership. There is also comparatively weak support for nonprofit and public housing, perhaps indicating a preference for true communitycontrolled models of decommodified housing.

Political education and messaging should illuminate the role that nonprofit and public entities play in securing stable, affordable homes, alongside opportunities to learn about examples of successful community-controlled housing. Qualitative research could explore the relative lack of enthusiasm for non-profit and public housing among Cully's housing activists.

\section{What are the limits to solidarity among neighbors, across lines of housing interest groups?}

Somewhat surprisingly, no statistically significant differences were found in housing consciousness or support for interventions based on either current 
housing tenure or housing interest group. Neither current homeowners nor aspirational homeowners placed a significantly higher priority on the exchange value aspects of homeownership, nor did they exhibit lower support for interventions in the homeownership market. Similarly, renters did not exhibit higher support for interventions in the rental market.

These findings bode well for solidarity within the Cully neighborhood. However, as noted in chapter 6, Living Cully's organizing to-date has not been particularly radical in its analysis and demands - especially when it comes to measures that would threaten the property value interests of homeowners. A renewed emphasis on political education, structural analysis and building a proactive agenda for housing decommodification - especially with relation to homeownership - may well strain existing solidarities.

These conclusions, combined with the observations shared at the end of chapter 6, provide a work plan and agenda to guide Living Cully's next steps toward building a truly radical housing movement that is inclusive, powerful and equipped to fight for the decommodification of housing in the Cully neighborhood and beyond.

\section{Limitations and possibilities for future research}

This study has a specific, limited goal: assess the potential for a radical housing movement in one neighborhood by examining the perspectives and priorities of the people who are already engaged in affordable housing activism. 
Given this limited scope of inquiry, there are several noteworthy limitations to the knowledge that has been generated, and corresponding suggestions for further research.

As discussed in chapter 8 , recruitment of survey participants was restricted by the Institutional Review Board at Portland State University. As an activist researcher and community organizer who has built relationships over time with community members, my study would have been more robust had I been able to personally recruit participants and encourage them to take the survey. This was not permitted, which limited participation to those who attended Living Cully's regular monthly housing advocacy meetings in September 2018, and those who took the survey online after receiving an invitation through Living Cully's e-mail list.

If I had been able to integrate survey recruitment more naturally with my work as a community organizer, I would have focused on recruitment among African Americans who have become involved in Living Cully more recently but as of yet do not regularly attend the monthly meetings. I also would have recruited former residents of the Normandy Apartments who were displaced from the neighborhood by a rent increase in 2017 and residents of the Oak Leaf Mobile Home Park who are temporarily relocated to housing outside of Cully while major renovations are being made to their park. Living outside of Cully at the time the survey was administered, these two groups of residents did not 
attend the meetings and were therefore underrepresented among survey respondents, despite having played a large part in Living Cully's housing advocacy over the past three years.

A major methodological limitation to this research is its use of exclusively qualitative methods. I believe that the survey data provide an important point-intime baseline measure of the level of housing consciousness among Cully's existing activists. However, these data provide very little insight into the process of consciousness development at either the individual or group scale. Interviews or focus groups could delve into individual participants' stories in order to understand how and why they got involved, and how their participation has changed their perspectives and priorities over time.

Focus groups could provide particularly relevant data, as they mimic the community organizing setting in a way that surveys do not; they get people talking to each other and learning from one another. Spanish language focus groups might provide insight into the handful of survey questions for which there were statistically significant differences between Spanish and English respondents. For example, Spanish speakers were more likely to support the concept of housing as a market commodity - translated in the survey as mercancia del mercado - than English speakers. Qualitative methods could explore whether this discrepancy is related to the concept itself, its translation into Spanish, cultural factors, or something else. 
Along with research using qualitative methods, the Cully Housing Advocacy Survey could be administered again in the future, after Living Cully has implemented the recommendations for its community organizing practice that are discussed earlier in this chapter. Success toward cultivating a radical housing movement could be assessed by comparing survey data between the two points-in-time to see if levels of housing consciousness are more advanced in the future.

The survey could be administered to other populations. Data collected from housing activists in other neighborhoods could be compared with data from the Cully respondents. Surveys could also be collected from residents who are not already engaged in housing activism. In 2018 Portland, the affordable housing crisis is one of the city's most prevalent social and political issues; a comparison between activists and non-activists could provide insight into the latent level of housing consciousness within the general population.

Finally, future research among housing activists in Cully and beyond could be designed and carried out as a more authentic activist research endeavor, with community members centrally involved throughout the entire process, from research design to data collection to the interpretation and analysis of results (Hale 2001). I believe that my research followed much of the spirit of activist research, yet was in many ways a top-down process designed and implemented by me as an individual researcher. As a community organizer, 
I hope to strategically incorporate true activist research as a grassroots organizing practice in the future.

I am committed to making the findings presented in this paper relevant and intelligible to the Cully community, especially those who participated in the survey, through presentations and popular education formats such as workshops, group discussions or graphics-focused publications. Hale (2001) defines activist research as being "used, together with the people in question, to formulate strategies for transforming [unjust] conditions and to achieve the power necessary to make these strategies effective." By informing Living Cully's work to build a radical movement that fights for a right to housing, the findings of this research will help achieve that vision. 


\section{References}

Baranski, John (2007). "Something to Help Themselves": Tenant Organizing in San Francisco's Public Housing, 1965-1975. Journal of Urban History, 33(3), 418-442.

Barton, Stephen E. (1977). The Urban Housing Problem: Marxist Theory and Community Organizing. Review of Radical Political Economics, 9(4), 1630.

Bates, Lisa (2013, May). Gentrification and Displacement Study: implementing an equitable, inclusive development strategy in the context of gentrification. Commissioned by City of Portland, Bureau of Planning and Sustainability. Retrieved from: http://www.portlandoregon.gov/bps/article/454027

Beauregard, Robert A. (1986). The Chaos and Complexity of Gentrification. In Smith \& Williams (Eds.), Gentrification of the City (pp. 35-55). Boston, MA: Allen \& Unwin.

Brenner, Neil (2009). What is critical urban theory? City, 13, 2-3.

Bruenig, Matt (2018, March 9). How Capitalist is Singapore Really? People's Policy Project. Retrieved from: https://www.peoplespolicyproject.org/2018/03/09/how-capitalist-issingapore-really/

Castells, Manuel (1983). The City and the Grassroots. Berkeley, CA: University of California Press.

Cohen, Helen S. \& Lipman, Mark (Producers). (2016). Arc of Justice: The Rise, Fall and Rebirth of a Beloved Community [Motion picture]. San Francisco: Open Studio Productions.

Cordell, Kasey (2013, March 22). Portland's Hottest Microhoods. Portland Monthly. Retrieved from: https://www.pdxmonthly.com/articles/2013/3/22/portlands-hottestmicrohoods-march-2013

Cummings, Scott L. (2001). Community Economic Development as Progressive Politics: Toward a Grassroots Movement for Social Justice. Stanford Law Review, 54(3), 399-493.

Damewood, Andrea (2016, October 18). NE 42 ${ }^{\text {nd }}$ Is Portland's New Restaurant Row. Portland Mercury. Retrieved from: https://www.portlandmercury.com/eat-and-drink-fall2016/2016/10/18/18636351/ne-42nd-is-portlands-new-restaurant-row

Davidson, Justin (2014, February 2). Is Gentrification All Bad? New York 
Magazine. Retrieved from:

http://nymag.com/news/features/gentrification-2014-2/

Davis, John Emmeus (1991). Contested Ground: Collective Action and the Urban Neighborhood. Ithaca, NY: Cornell University Press.

DeFilippis, James (2004). Unmaking Goliath: Community Control in the Face of Global Capital. New York, NY: Routledge.

Desmond, Matthew (2016). Evicted: Poverty and Profit in the American City. New York, NY: Crown Publishers.

Dreier, Peter (2006). Federal Housing Subsidies: Who Benefits and Why? In Bratt, Stone \& Hartman (Eds.), A Right to Housing: Foundation for a New Social Agenda (pp. 105-138). Philadelphia, PA: Temple University Press.

European Federation of Public, Cooperative and Social Housing. (2010). Social Housing in Europe: The Netherlands. Retrieved from: http://www.housingeurope.eu/resource-117/social-housing-in-europe

Fainstein, Susan (2010). The Just City. Ithaca, NY: Cornell University Press.

Fainstein, Norman \& Fainstein, Susan (1974). Urban Political Movements: The Search for Power by Minority Groups in American Cities. Englewood Cliffs, NJ: Prentice-Hall.

Fullilove, Mindy \& Wallace, Rodrick (2011). Serial Forced Displacement in American Cities, 1916-2010. Journal of Urban Health, 88(3), 381-389.

Gallaher, Carolyn (2016). The Politics of Staying Put. Philadelphia, PA: Temple University Press.

Gee, Alastair (2017, December 6). America's homeless population rises for the first time since the Great Recession. The Guardian. Retrieved from https://www.theguardian.com/us-news/2017/dec/05/america-homelesspopulation-2017-official-count-crisis

Gibson, Karen (2007). Bleeding Albina: A history of community disinvestment, 1940-2000. Transforming Anthropology, 15(1), 3-25.

Goldman, Michal \& Brodsky, Ellen (Producers). (2008). At Home in Utopia [Motion picture]. United States: New Day Films.

Gray, Karen A. \& Galande, Mugdha (2011). Keeping "Community" in a community land trust. Social Work Research, 35(4), 241-248.

Gunn, Christopher \& Gunn, Hazel Dayton (1991). Reclaiming Capital: Democratic Initiatives and Community Development. Ithaca, NY: Cornell University Press.

Hackworth, Jason (2007). The Neoliberal City: Governance, Ideology, and Development in American Urbanism. Ithaca, NY: Cornell University Press. 
Hale, Charles R. (2001). What is Activist Research? Social Science Research Council: Items and Issues, 2(1-2), 13-15.

Hartman, Chester (1998). The case for a right to housing. Housing Policy Debate, 9(2), 223-246.

Hartman, Chester \& Robinson, David (2003). Evictions: The Hidden Housing Problem. Housing Policy Debate, 14(4), 461-501.

Harvey, David (2012). Rebel Cities: From the Right to the City to the Urban Revolution. London: Verso.

Hern, Matt (2016). What a City Is For: Remaking the Politics of Displacement. Cambridge, MA: The MIT Press.

Herrington, Cameron \& Dann, Ryan J. (2016). Is Portland's bicycle success story a celebration of gentrification? In Golub, Hoffmann, Lugo \& Sandoval (Eds.), Bicycle Justice and Urban Transformation (pp. 32-52). New York, NY: Routledge.

Hertz, Daniel (2016, July 20). Housing can't be a good investment and affordable. CityObservatory. Retrieved from http://cityobservatory.org/housing-cant-be-a-good-investment-andaffordable/

Hewitt, Lyndsey (2017, May 24). Activist group shames landlord who hiked rent of 18 Northeast Portland families. Portland Tribune. Retrieved from: https://pamplinmedia.com/pt/9-news/360442-240510-activist-groupshames-landlord-who-hiked-rent-of-18-northeast-portland-families

Jacobs, Jane (1961). The Death and Life of Great American Cities. New York, NY: Random House.

King, Steve (2017, April 25). Thoughts on the Unnatural Occurrence of Cheap Housing. Shelterforce. Retrieved from

https://shelterforce.org/2017/04/25/thoughts-unnatural-occurrencecheap-housing/

Law, Steve (2016, December 7). Embattled mobile home park residents saved from eviction. Portland Tribune. Retrieved from:

https://pamplinmedia.com/pt/9-news/335450-215459-embattled-mobilehome-park-residents-saved-from-eviction-

Leavitt, Jacqueline \& Saegert, Susan (1990). From abandonment to hope: community-households in Harlem. New York, NY: Columbia University Press.

Logan, John R. \& Molotch, Harvey (1987). Urban Fortunes: The Political Economy of Place. Berkeley, CA: University of California Press.

Madden, David \& Marcuse, Peter (2016). In Defense of Housing. Brooklyn, NY: 
Verso.

Marcuse, Peter (1986). Abandonment, gentrification, and displacement: the linkages in New York City. In Smith \& Williams (Eds.), Gentrification of the City (ch. 8). Boston, MA: Allen \& Unwin.

Marcuse, Peter (1999). Housing Movements in the USA. Housing, Theory and Society, 16, 67-86.

Marcuse, Peter (2012). A Critical Approach to Solving the Housing Problem. In Brenner, Marcuse \& Mayer (Eds.), Cities for People, Not for Profit (pp. 215-230). New York, NY: Routledge.

Marcuse, Peter \& Keating, W. Dennis (2006). The Permanent Housing Crisis: The Failures of Conservatism and the Limitations of Liberalism. In Bratt, Stone \& Hartman (Eds.), A Right to Housing: Foundation for a New Social Agenda (pp. 139-162). Philadelphia, PA: Temple University Press.

Mayer, Margit (2012). The "Right to the City" in Urban Social Movements. In Brenner, Marcuse \& Mayer (Eds.), Cities for People, Not for Profit (pp. 6385). New York, NY: Routledge.

Medoff, Peter \& Sklar, Holly (1994). Streets of Hope: The Fall and Rise of an Urban Neighborhood. Boston, MA: South End Press.

Monahan, Rachel \& Mesh, Aaron (2018, July 4). A Five-Alarm Fire at a Junkyard Sent Toxic Smoke Billowing Through a Portland Residential

Neighborhood. State Regulators Had Looked the Other Way. Willamette Week. Retrieved from: https://www.wweek.com/news/2018/07/04/a-fivealarm-fire-at-a-junkyard-sent-toxic-smoke-billowing-through-a-portlandresidential-neighborhood-state-regulators-had-looked-the-other-way/

Monello Schloming, Lenore \& Schloming, Skip (1993). Comment on Chester Hartman and David Robinson's "Evictions: The Hidden Housing Problem." Housing Policy Debate, 14(4), 529-540.

Newman, Kathe \& Wyly, Elvin K. (2006). The Right to Stay Put, Revisited: Gentrification and Resistance to Displacement in New York City. Urban Studies, 43(1), 23-57.

Piven, Frances Fox \& Cloward, Richard (1977). Poor People's Movements: Why They Succeed, How They Fail. New York, NY: Vintage.

Portland Housing Bureau (2017, Fall). State of Housing in Portland. Retrieved from https://www.portlandoregon.gov/phb/article/681253

Purcell, Mark (2002). Excavating Lefebvre: The Right to the City and its Urban Politics of the Inhabitant. GeoJournal, 59, 99-108.

Ray, Cass (2017, August 23). Tensions Rise Between Portland Neighborhood and Homeless Village. Oregon Public Broadcasting. Retrieved from: 
https://www.opb.org/radio/programs/think-out-loud/article/portlandhazelnut-grove-overlook-rule-homeless-voting/

Rooney, Jim (1995). Organizing the South Bronx. Albany, NY: State University of New York Press.

Rothstein, Richard (2017). The Color of Law: A Forgotten History of How Our Government Segregated America. New York, NY: Liverlight.

Saegert, Susan, Eizenberg, E., Extein, M., Hsieh, T., Benítez, L. \& Chang, C. (2003). Limited equity co-ops as bulwarks against gentrification. Paper presented at the conference of the Urban Affairs Association, Cleveland.

Saegert, Susan \& Winkel, Gary (1996). Paths to Community Empowerment: Organizing at Home. American Journal of Community Psychology, 24(4), 517-550.

Shlay, A. B. (2006). Low-income homeownership: American dream of delusion? Urban Studies, 43(3), 511-531.

Smith, Neil (1987). Commentary: Gentrification and the Rent Gap. Annals of the Association of American Geographers, 77(3), 462-465.

Smith, Neil (2002). New Globalism, New Urbanism: Gentrification as Global Urban Strategy. Antipode, 34(3), 427-450.

Solomon, Molly and Phoebe Flanigan (2017, February 25). Hundreds March in Northeast Portland Rally to Protest Rent Hikes. Oregon Public Broadcasting. Retrieved from: https://www.opb.org/news/article/portland-rent-increase-rally-normandy/

Squires, Gregory (1994). Capital and Communities in Black and White: The Intersections of Race, Class and Uneven Development. New York, NY: State University of New York.

Stewart, Hailey (2018, July 2). Old 25-acre landfill officially becomes new Cully Park. Portland Tribune. Retrieved from: https://portlandtribune.com/pt/9news/399895-295398-old-25-acre-landfill-officially-becomes-new-cullypark

Stoecker, Randy (1994). Defending Community: The Struggle for Alternative Redevelopment in Cedar-Riverside. Philadelphia, PA: Temple University Press.

Stoecker, Randy (1997). The CDC Model of Urban Redevelopment: A Critique and an Alternative. Journal of Urban Affairs, 19(1), 1-22.

Stoecker, Randy (2003). Understanding the Development-Organizing Dialectic. Journal of Urban Affairs, 25(4), 493-512.

Stone, Michael E. (2006). Housing Affordability: One-Third of a Nation ShelterPoor. In Bratt, Stone \& Hartman (Eds.), A Right to Housing: Foundation 
for a New Social Agenda (pp. 38-60). Philadelphia, PA: Temple University Press.

Stone, Michael E. (2008). Social Housing. In DeFilippis \& Saegert (Eds.), The Community Development Reader (pp. 67-80). New York, NY: Routledge.

Streitfeld, David \& Thee-Brenan, Megan (2011, June 29). Despite risks, owning a home retains its allure, poll shows. The New York Times. Retrieved from https://www.nytimes.com/2011/06/30/business/30poll.html

Sturrock, Carrie (2011, August 23). Cully Grove co-housing community in Northeast Portland open house Sunday Aug. 28: just six units left. Oregonlive.com. Retrieved from:

http://blog.oregonlive.com/pdxgreen/2011/08/cully grove cohousing communi.html

Swyngedouw, Erik (2007). Impossible "Sustainability" and the Postpolitical Condition. In Krueger \& Gibbs (Eds.), The Sustainable Development Paradox. New York, NY: The Guilford Press.

Thaden, Emily, Greer, Andrew \& Saegert, Susan (2013). Shared Equity Homeownership: A Welcomed Tenure Alternative Among Lower Income Households. Housing Studies, 28(8), 1175-1196.

Tracy, James (2014). Dispatches Against Displacement: Field Notes From San Francisco's Housing Wars. Oakland, CA: AK Press.

VanderHart, Dirk (2017, February 2). No-Cause Evicted? Landlords Now Have to Pay Your Relocation Costs. Portland Mercury. Retrieved from: https://www.portlandmercury.com/blogtown/2017/02/02/18830162/liveblog-will-portland-enact-strong-new-renter-protections-today

Waldroupe, Amanda (2017, November 3). So long, Sugar Shack: Affordable housing planned at Living Cully Plaza. Street Roots. Retrieved from: https://news.streetroots.org/2017/11/03/so-long-sugar-shack-affordablehousing-planned-living-cully-plaza

Weiner, Rachel (2012, April 16). Mitt Romney at private fundraiser: I might eliminate HUD. The Washington Post. Retrieved from: http://www.washingtonpost.com/blogs/the-fix/post/mitt-romney-atprivate-fundraiser-i-might-eliminatehud/2012/04/16/glQA5QuKLT blog.html

Willis, Jay (2016, June 14). Why blaming the homeless makes people feel better. Crosscut. Retrieved from https://crosscut.com/2016/06/why-blamingthe-homeless-makes-us-feel-better

Wright, James D., Rubin, Beth \& Devine, Joel (1998). Beside the Golden Door: Policy, Politics, and the Homeless. New York, NY: Aldine de Gruyter. 


\section{Appendix A: Cully Housing Advocacy Survey (data collection instrument) \\ Cully Housing Advocacy Survey}

You are being invited to participate in a research study about housing and affordable housing advocacy in the Cully neighborhood. This study is being conducted by Cameron Herrington from Living Cully and Dr. Karen Gibson from the School of Urban Studies and Planning at Portland State University. This study is part of Cameron Herrington's research for his master's thesis at Portland State, and is funded by Living Cully.

There are no known risks if you decide to participate in this research study. There are no costs to you for participating in the study. The information you provide will help Living Cully to be more effective in its advocacy for affordable housing in Portland. The questionnaire will take about 20 minutes to complete. The information collected may not benefit you directly, but the information learned in this study should provide more general benefits for the Cully community. You will receive a $\$ 10$ gift card in appreciation of your time.

This survey is anonymous; you will not be asked to provide your name. No one will be able to identify you or your answers. No one from Living Cully will know whether or not you participated in the study. Individuals from the Institutional Review Board at Portland State may inspect these records. Should the data be published, no individual information will be disclosed.

Your participation in this study is voluntary. By completing and returning the survey, you are voluntarily agreeing to participate. You are free to skip any particular question you do not wish to answer for any reason, and you are free to stop taking the survey at any time.

If you have any questions about the study, please contact:

Dr. Karen Gibson

Portland State University, Toulan School of Urban Studies and Planning 503.725 .8265

gibsonk@pdx.edu

The Portland State University Institutional Review Board has reviewed this project. If you have any concerns about your rights in this study, please contact the PSU Office of Research Integrity at (503) 725-2227 or email hsrrc@pdx.edu

SURVEY BEGINS ON NEXT PAGE 
Have you already responded to this survey, either online or on paper?

$\square$ Yes $\square$ No

What is your age?

$\begin{array}{lllll}\square & \square & \square & \square & \square \\ \text { Under } 18 & 18-34 & 35-49 & 50-64 & 65 \text { and older }\end{array}$

Have you ever participated in affordable housing advocacy/activism for the Cully neighborhood?

$\square$ Yes $\square$ No 


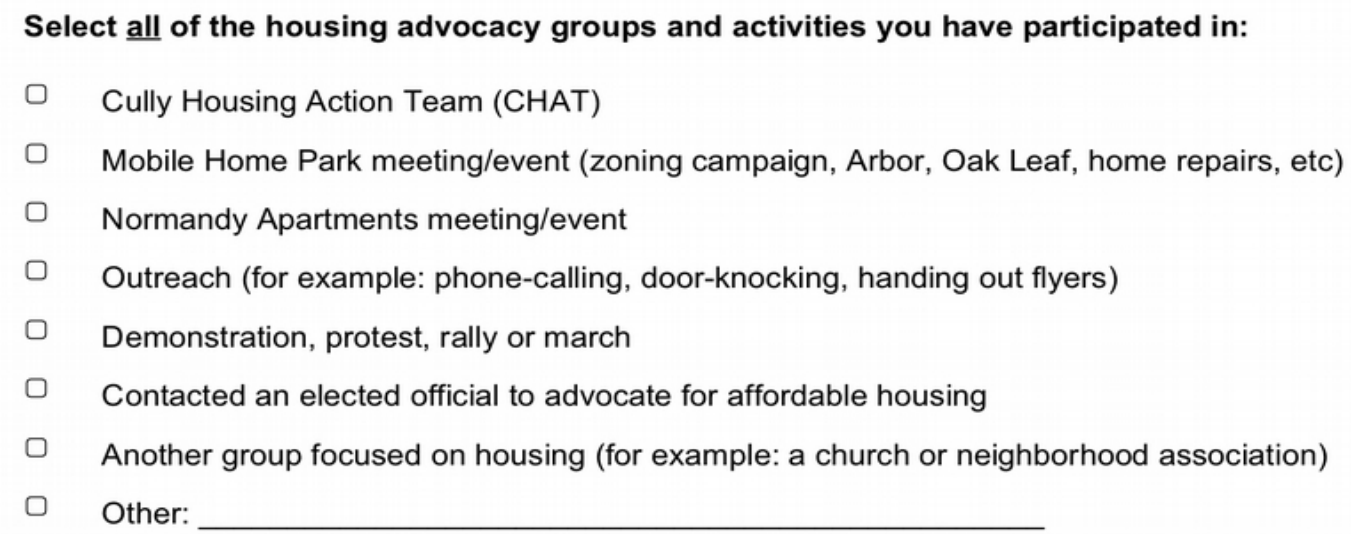

What is your current housing situation? Select one option:

$\square \quad$ I own my own home (not a mobile home/trailer)

$\square \quad$ I rent from a private/for-profit landlord

$\square \quad$ I rent from a public or non-profit landlord (example: Hacienda CDC)

- I own my own mobile home/trailer (and rent the space)

$\square \quad$ I rent a mobile home/trailer from the landlord

$\square \quad$ I am homeless or in a temporary living situation

$\square$ Other: 
What is your goal for your family's housing in the next 10 years? Select one option:

$\square \quad$ Stay in my current home

$\square \quad$ Move to a rental home

○ Purchase a mobile home/manufactured home/trailer

$\square$ Purchase a house or condominium

Other:

Do you agree or disagree with the following statement?

I often have trouble affording my monthly housing costs.

$\begin{array}{lllll}\square & \square & \square & 0 & \square \\ \begin{array}{l}\text { Strongly } \\ \text { agree }\end{array} & \begin{array}{l}\text { Somewhat } \\ \text { agree }\end{array} & \text { Neutral } & \begin{array}{l}\text { Somewhat } \\ \text { disagree }\end{array} & \begin{array}{l}\text { Strongly } \\ \text { disagree }\end{array}\end{array}$

Do you agree or disagree with the following statement?

I can't afford all of the things that my family and I need because we spend too much for our housing.

$\begin{array}{lllll}\square & \square & \square & 0 & \square \\ \begin{array}{l}\text { Strongly } \\ \text { agree }\end{array} & \begin{array}{l}\text { Somewhat } \\ \text { agree }\end{array} & \text { Neutral } & \begin{array}{l}\text { Somewhat } \\ \text { disagree }\end{array} & \begin{array}{l}\text { Strongly } \\ \text { disagree }\end{array}\end{array}$

Imagine that you are looking for a new home to buy. Which two things would be most important to you and your family? Select two options:

$\square$ Location: Your home is in a good location for your family. It is in a safe, healthy neighborhood, and close to the places you want to go.

$\square$ Condition: Your home is in good condition and does not need repairs. It is safe, healthy and comfortable all year long. It is energy-efficient.

$\square \quad$ Future value: Your home will gain value over time, so you can sell it for more than you paid when you bought it.

$\square \quad$ Size: Your home is the right size for your family, not too big or too small. There are enough bedrooms for everyone.

O Outdoor areas: You home has the outdoor spaces that are most important to you (for example a yard, garden, patio, or parking). This could include private areas or shared areas. 
What are the two most important advantages of being a homeowner? Select two options:

Stability: You can stay in your home for as long as you want. Your monthly costs won't go up, and you won't be evicted or displaced.

$\square$ Control and privacy: You are in charge of your own home. You can paint, decorate and renovate. There is no landlord.

- Build wealth: Instead of paying rent to a landlord, each month you pay back the bank that gave you a loan to buy your home. If you sell your home, you will get back the money you have paid to the bank, instead of losing the money you would pay to a landlord if you were a renter.

- Make a profit: In the future you could sell your home for a higher price than you paid when you bought it. This profit would be in addition to getting back the money you paid to the bank each month to repay your loan.

Give your home to your family: In the future you could give your home to your children or family members.

Owning a home can provide stable housing for your family. It can also be a way to gain wealth, especially if your home goes up in value and you sell it in the future.

Which one of these is more important to you?

Having stable housing is more important.

Gaining wealth is more important.

$\square \quad$ Having stable housing and gaining wealth are equally important.

Do you agree or disagree with the following statement?

Housing should be a human right. Everyone deserves a good home at a price they can afford.

$\begin{array}{lllll}\square & \square & \square & \square & \square \\ \begin{array}{l}\text { Strongly } \\ \text { agree }\end{array} & \begin{array}{l}\text { Somewhat } \\ \text { agree }\end{array} & \text { Neutral } & \begin{array}{l}\text { Somewhat } \\ \text { disagree }\end{array} & \begin{array}{l}\text { Strongly } \\ \text { disagree }\end{array}\end{array}$

Do you agree or disagree with the following statement?

Lower-income people deserve to have stable homes in the Cully neighborhood.

$\begin{array}{lllll}\square & \square & \square & \square & \square \\ \begin{array}{l}\text { Strongly } \\ \text { agree }\end{array} & \begin{array}{l}\text { Somewhat } \\ \text { agree }\end{array} & \text { Neutral } & \begin{array}{l}\text { Somewhat } \\ \text { disagree }\end{array} & \begin{array}{l}\text { Strongly } \\ \text { disagree }\end{array}\end{array}$

Do you agree or disagree with the following statement?

Housing should generally be treated as a commodity on the market. People should have access to whatever housing they can afford to pay for (as with cars and groceries).

$\begin{array}{lllll}\square & \square & \square & \square & \square \\ \begin{array}{l}\text { Strongly } \\ \text { agree }\end{array} & \begin{array}{l}\text { Somewhat } \\ \text { agree }\end{array} & \text { Neutral } & \begin{array}{l}\text { Somewhat } \\ \text { disagree }\end{array} & \begin{array}{l}\text { Strongly } \\ \text { disagree }\end{array}\end{array}$


Do you agree or disagree with the following statement?

Housing should generally be treated as a public good. Everyone should have access to housing, no matter how much they can afford to pay (as with schools and parks).

$\begin{array}{lllll}\square & \square & \square & \square & \square \\ \begin{array}{l}\text { Strongly } \\ \text { agree }\end{array} & \begin{array}{l}\text { Somewhat } \\ \text { agree }\end{array} & \text { Neutral } & \begin{array}{l}\text { Somewhat } \\ \text { disagree }\end{array} & \begin{array}{l}\text { Strongly } \\ \text { disagree }\end{array}\end{array}$

Do you agree or disagree with the following statement?

In general, the housing market is working well for low-income people in the Cully neighborhood.

$\begin{array}{lllll}\square & \square & \square & \square & \square \\ \begin{array}{l}\text { Strongly } \\ \text { agree }\end{array} & \begin{array}{l}\text { Somewhat } \\ \text { agree }\end{array} & \text { Neutral } & \begin{array}{l}\text { Somewhat } \\ \text { disagree }\end{array} & \begin{array}{l}\text { Strongly } \\ \text { disagree }\end{array}\end{array}$

Do you agree or disagree with the following statement?

Rising rents are causing low-income families in Cully to lose their homes.

$\begin{array}{lllll}\square & \square & \square & \square & \square \\ \begin{array}{l}\text { Strongly } \\ \text { agree }\end{array} & \begin{array}{l}\text { Somewhat } \\ \text { agree }\end{array} & \text { Neutral } & \begin{array}{l}\text { Somewhat } \\ \text { disagree }\end{array} & \begin{array}{l}\text { Strongly } \\ \text { disagree }\end{array}\end{array}$

Do you agree or disagree with the following statement?

It is getting harder for low-income families to own a home in Cully.

$\begin{array}{lllll}\square & \square & \square & \square & \square \\ \begin{array}{l}\text { Strongly } \\ \text { agree }\end{array} & \begin{array}{l}\text { Somewhat } \\ \text { agree }\end{array} & \text { Neutral } & \begin{array}{l}\text { Somewhat } \\ \text { disagree }\end{array} & \begin{array}{l}\text { Strongly } \\ \text { disagree }\end{array}\end{array}$

Do you agree or disagree with the following statement?

If things don't change, Cully will become a neighborhood where only wealthy people can afford to live.

$\begin{array}{lllll}\square & \square & \square & \square & \square \\ \begin{array}{l}\text { Strongly } \\ \text { agree }\end{array} & \begin{array}{l}\text { Somewhat } \\ \text { agree }\end{array} & \text { Neutral } & \begin{array}{l}\text { Somewhat } \\ \text { disagree }\end{array} & \begin{array}{l}\text { Strongly } \\ \text { disagree }\end{array}\end{array}$

Do you agree or disagree with the following statement?

The value of homes is going up in Cully. Overall, this is good for the neighborhood.

$\begin{array}{lllll}\square & \square & \square & \square & \square \\ \begin{array}{l}\text { Strongly } \\ \text { agree }\end{array} & \begin{array}{l}\text { Somewhat } \\ \text { agree }\end{array} & \text { Neutral } & \begin{array}{l}\text { Somewhat } \\ \text { disagree }\end{array} & \begin{array}{l}\text { Strongly } \\ \text { disagree }\end{array}\end{array}$


Do you agree or disagree with the following statement?

Rents are going up in Cully. Overall, this is good for the neighborhood.

$\begin{array}{lllll}\square & \square & \square & \square & \square \\ \begin{array}{l}\text { Strongly } \\ \text { agree }\end{array} & \begin{array}{l}\text { Somewhat } \\ \text { agree }\end{array} & \text { Neutral } & \begin{array}{l}\text { Somewhat } \\ \text { disagree }\end{array} & \begin{array}{l}\text { Strongly } \\ \text { disagree }\end{array}\end{array}$

When the cost to buy a house is too high for a low-income family to afford, who is most to blame? Select one option:

The low-income family, because they don't have enough money to buy the house.

$\square \quad$ The seller, because they set such a high price.

$\square$ No one is to blame; this is how the market works.

$\square \quad$ The politicians, because they haven't done anything to limit the price that a house can be sold for.

$\square \quad$ The entire housing system is to blame, because it allows homeowners to make a profit by selling for the highest possible price.

When the rent goes up and a low-income family is forced to move out, who is most to blame? Select one option:

$\square \quad$ The low-income family, because they don't have enough money to pay the rent.

$\square \quad$ The landlord, because they raised the rent so high.

$\square \quad$ No one is to blame; this is how the market works.

$\square \quad$ The politicians, because they haven't done anything to prevent the rent increase.

$\square \quad$ The entire housing system is to blame, because it allows landlords to make a profit by raising the rent.

Do you agree or disagree with the following statement?

When property values go up, homeowners benefit at the expense of people who don't own homes.

$\begin{array}{lllll}\square & \square & \square & \square & \square \\ \begin{array}{l}\text { Strongly } \\ \text { agree }\end{array} & \begin{array}{l}\text { Somewhat } \\ \text { agree }\end{array} & \text { Neutral } & \begin{array}{l}\text { Somewhat } \\ \text { disagree }\end{array} & \begin{array}{l}\text { Strongly } \\ \text { disagree }\end{array}\end{array}$

Do you agree or disagree with the following statement?

When rents go up, landlords benefit at the expense of renters.

$\begin{array}{lllll}\square & \square & \square & \square & \square \\ \begin{array}{l}\text { Strongly } \\ \text { agree }\end{array} & \begin{array}{l}\text { Somewhat } \\ \text { agree }\end{array} & \text { Neutral } & \begin{array}{l}\text { Somewhat } \\ \text { disagree }\end{array} & \begin{array}{l}\text { Strongly } \\ \text { disagree }\end{array}\end{array}$


Do you agree or disagree with the following statement?

Rising housing costs hurt everyone.

$\begin{array}{lllll}\square & \square & \square & \square & \square \\ \begin{array}{l}\text { Strongly } \\ \text { agree }\end{array} & \begin{array}{l}\text { Somewhat } \\ \text { agree }\end{array} & \text { Neutral } & \begin{array}{l}\text { Somewhat } \\ \text { disagree }\end{array} & \begin{array}{l}\text { Strongly } \\ \text { disagree }\end{array}\end{array}$

Do you agree or disagree with the following statement?

In order for everyone to have stable housing that they can afford, property owners will need to lose some of their wealth.

$\begin{array}{lllll}\square & \square & \square & \square & \square \\ \begin{array}{l}\text { Strongly } \\ \text { agree }\end{array} & \begin{array}{l}\text { Somewhat } \\ \text { agree }\end{array} & \text { Neutral } & \begin{array}{l}\text { Somewhat } \\ \text { disagree }\end{array} & \begin{array}{l}\text { Strongly } \\ \text { disagree }\end{array}\end{array}$

Do you agree or disagree with the following statement?

More housing should be owned by the government and non-profit organizations, instead of by families and companies.

$\begin{array}{lllll}\square & \square & \square & \square & \square \\ \begin{array}{l}\text { Strongly } \\ \text { agree }\end{array} & \begin{array}{l}\text { Somewhat } \\ \text { agree }\end{array} & \text { Neutral } & \begin{array}{l}\text { Somewhat } \\ \text { disagree }\end{array} & \begin{array}{l}\text { Strongly } \\ \text { disagree }\end{array}\end{array}$

Do you agree or disagree with the following statement?

There should be new laws to limit rent increases.

$\begin{array}{lllll}\square & \square & \square & \square & \square \\ \begin{array}{l}\text { Strongly } \\ \text { agree }\end{array} & \begin{array}{l}\text { Somewhat } \\ \text { agree }\end{array} & \text { Neutral } & \begin{array}{l}\text { Somewhat } \\ \text { disagree }\end{array} & \begin{array}{l}\text { Strongly } \\ \text { disagree }\end{array}\end{array}$

Do you agree or disagree with the following statement?

There should be new laws to limit how much a homeowner can sell their home for.

$\begin{array}{lllll}\square & \square & \square & \square & \square \\ \begin{array}{l}\text { Strongly } \\ \text { agree }\end{array} & \begin{array}{l}\text { Somewhat } \\ \text { agree }\end{array} & \text { Neutral } & \begin{array}{l}\text { Somewhat } \\ \text { disagree }\end{array} & \begin{array}{l}\text { Strongly } \\ \text { disagree }\end{array}\end{array}$

Do you agree or disagree with the following statement?

Homeowners who make a profit by selling their homes should pay higher taxes, in order to create funds for affordable housing.

$\begin{array}{lllll}\square & \square & \square & \square & \square \\ \begin{array}{l}\text { Strongly } \\ \text { agree }\end{array} & \begin{array}{l}\text { Somewhat } \\ \text { agree }\end{array} & \text { Neutral } & \begin{array}{l}\text { Somewhat } \\ \text { disagree }\end{array} & \begin{array}{l}\text { Strongly } \\ \text { disagree }\end{array}\end{array}$


Do you agree or disagree with the following statement?

Landlords who make a profit by selling an apartment building or raising the rent should pay higher taxes in order to create funds for affordable housing.

$\begin{array}{lllll}\square & \square & \square & \square & \square \\ \begin{array}{l}\text { Strongly } \\ \text { agree }\end{array} & \begin{array}{l}\text { Somewhat } \\ \text { agree }\end{array} & \text { Neutral } & \begin{array}{l}\text { Somewhat } \\ \text { disagree }\end{array} & \begin{array}{l}\text { Strongly } \\ \text { disagree }\end{array}\end{array}$

In a perfect world, which of these two systems for homeownership would be best for the Cully neighborhood?

It is more affordable to buy a home, because homeowners cannot make a profit when they sell. The cost of buying a house is lower, so more low-income families can afford to buy. But when you sell your house, you are not allowed to sell it for more than you paid when you bought it. This keeps the house affordable for future buyers.

$\square \quad$ It is more expensive to buy a home, because homeowners can make a profit when they sell. The cost of buying a house is higher, so fewer low-income families can afford to buy. But if you are able to buy a house, you can sell it in the future for a higher price than you paid when you bought it. This allows your family to gain wealth.

$\square \quad$ I have no preference.

Have you ever been homeless? Select all that apply:

$\square$ NO $\square$ YES, when I was growing up $\square$ YES, as an adult

Did your family ever own your own home when you were growing up?

$\square$ No $\square$ Yes

As an adult, have you ever lost your housing or been forced to move?

$\square$ NO If YES, why? Select all that apply:

$\square$ Eviction $\square$ Rent increase $\square$ Foreclosure $\square$ Other:

As an adult, have you ever made a profit by owning a home that gained value after you bought it? Either your current home, or a home that you owned in the past.

$\square$ No $\square$ Yes

Have you ever lived in the Cully neighborhood? Select one option:

$\square$ I currently live in Cully $\quad \square$ I used to live in Cully, but not now $\square$ I have never lived in Cully

What is the zip code where you currently live? 
What gender do you identify with?

$\square$ Female $\square$ Male $\square$ Non-binary $\quad \square$ I prefer not to respond

What race or ethnic group do you identify with? Select one or more:

$\begin{array}{llll}\square & \text { Black/African American } & \square \text { African } & \square \text { Asian } \\ \square & \text { Native American/Indigenous } & \square \text { Pacific Islander } & \square \text { White } \\ \square & \text { Other: } & \square \text { Latino/Hispanic } & \square \text { I prefer not to respond }\end{array}$

How many people in each age group live in your home (including yourself)?

$0-17$ years old: 18-34 years old: $35-49$ years old:

50-64 years old:

65 years and older:

How much does your household pay for your housing each month? Include rent or mortgage and utilities (water, garbage, electricity)

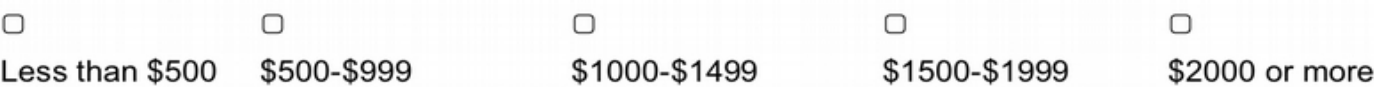

What is your approximate annual household income?

$\begin{array}{lllll}\square & \square & \square & \square & \square \\ \text { Less than } \$ 25,000 & \$ 25,000-49,999 & \$ 50,000-74,999 & \$ 75,000-99,999 & \$ 100,000 \text { or more }\end{array}$


Appendix B: Data Analysis Model

SECTION 1: Screening Questions

Q1.1

Have you already responded to this survey, either online or on paper?

$\square$ Yes $\square$ No

Q1.2

What is your age?

○ $\square \quad 0 \quad 0 \quad 0$

Under $18 \quad 18-34 \quad 35-49 \quad 50-64 \quad 65$ and older

Q1.3

Have you ever participated in affordable housing advocacy/activism for the Cully neighborhood?

$\square$ Yes $\square$ No 


\section{SECTION 2: Participation}

\section{Q2.1}

Select all of the housing advocacy groups and activities you have participated in:

$\square \quad$ Cully Housing Action Team (CHAT)

$\square \quad$ Mobile Home Park meeting/event (zoning campaign, Arbor, Oak Leaf, home repairs, etc)

$\square \quad$ Normandy Apartments meeting/event

$\square \quad$ Outreach (for example: phone-calling, door-knocking, handing out flyers)

D Demonstration, protest, rally or march

$\square \quad$ Contacted an elected official to advocate for affordable housing

$\square$ Another group focused on housing (for example: a church or neighborhood association)

Other:

Q2.2

Select the two most important reasons that you first got involved in housing advocacy:

$\square \quad$ I was facing a crisis or challenge with my own housing (for example: a threat of losing my home, or my home was in need of repair).

$\square \quad$ I wanted to support my neighbors who were facing a crisis or a challenge with their housing.

$\square \quad$ I was worried that I could face a crisis or challenge with my own housing in the future.

○ I was worried about the future of my neighborhood.

$\square \quad$ I believe the overall housing system needs to be changed.

$\square \quad$ I wanted to learn about housing issues and/or my rights. 


\section{SECTION 3: Housing Interest Group}

These questions allow for the creation of groups that can be compared with one another in the analysis of the subsequent sections

\section{Q3.1}

What is your current housing situation? Select one option:

- I own my own home (not a mobile home/trailer)

○ I rent from a private/for-profit landlord

$\square \quad$ I rent from a public or non-profit landlord (example: Hacienda CDC)

$\square \quad$ I own my own mobile home/trailer (and rent the space)

$\square \quad$ I rent a mobile home/trailer from the landlord

○ I am homeless or in a temporary living situation

$\square$ Other:

Q3.2

What is your goal for your family's housing in the next 10 years? Select one option:

$\square \quad$ Stay in my current home

$\square$ Move to a rental home

○ Purchase a mobile home/manufactured home/trailer

$\square \quad$ Purchase a house or condominium

Other:

\section{Q3.3}

Do you agree or disagree with the following statement? I often have trouble affording my monthly housing costs.

$\begin{array}{lllll}\square & \square & \square & \square & \square \\ \begin{array}{l}\text { Strongly } \\ \text { agree }\end{array} & \begin{array}{l}\text { Somewhat } \\ \text { agree }\end{array} & \text { Neutral } & \begin{array}{l}\text { Somewhat } \\ \text { disagree }\end{array} & \begin{array}{l}\text { Strongly } \\ \text { disagree }\end{array}\end{array}$

Q3.4

Do you agree or disagree with the following statement? I can't afford all of the things that my family and I need because we spend too much for our housing.

$\begin{array}{lllll}\square & \square & \square & \square & \square \\ \begin{array}{l}\text { Strongly } \\ \text { agree }\end{array} & \begin{array}{l}\text { Somewhat } \\ \text { agree }\end{array} & \text { Neutral } & \begin{array}{l}\text { Somewhat } \\ \text { disagree }\end{array} & \begin{array}{l}\text { Strongly } \\ \text { disagree }\end{array}\end{array}$


SECTION 4: Use vs. Exchange Value Priority

Composite Scale of $0-7$

High score $=$ priority on exchange value of housing, over use value

Q4.1 / 'Future value' = strong exchange value ideology

Max of 2 points toward composite score

Imagine that you are looking for a new home to buy. Which two things would be most important to you and your family? Select two options:

(0) Location: Your home is in a good location for your family...

(0) Condition: Your home is in good condition and does not need repairs...

(2) Future value: Your home will gain value over time...

(0) Size: Your home is the right size for your family...

(0) Outdoor areas: You home has the outdoor spaces that are most important to you...

Q4.2 I 'Make a profit' = strong exchange value priority; 'Build wealth' = moderate priority Max of 3 points toward composite score

What are the two most important advantages of being a homeowner? Select two options:

(0) Stability: You can stay in your home for as long as you want...

(0) Control and privacy: You are in charge of your own home...

(1) Build wealth: Instead of paying rent to a landlord, each month you pay back the bank...

(2) Make a profit: In the future you could sell your home for a higher price...

(0) Give your home to your family: In the future you could give your home...

Q4.3 / 'Gaining wealth' = strong exchange value priority; 'Equally important' = moderate priority Max of 2 points toward composite score

Owning a home can provide stable housing for your family. It can also be a way to gain wealth, especially if your home goes up in value and you sell it in the future.

Which one of these is more important to you?

(0) Having stable housing is more important.

(2) Gaining wealth is more important.

(1) Having stable housing and gaining wealth are equally important. 


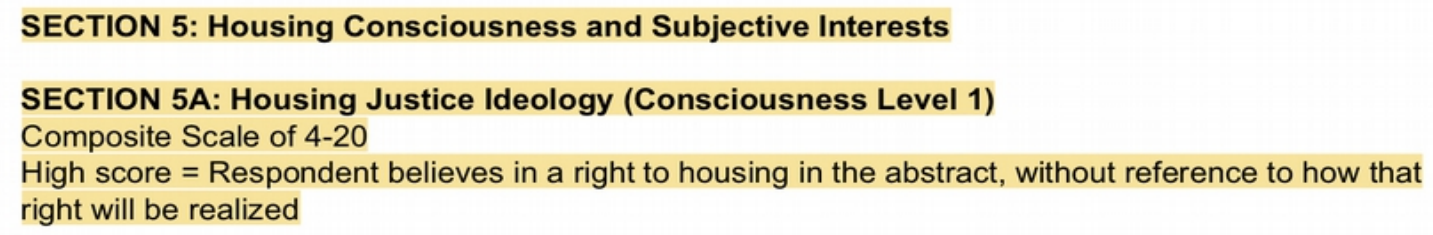

Q5A.1

Do you agree or disagree with the following statement?

Housing should be a human right. Everyone deserves a good home at a price they can afford.
$\square$
(5) Strongly
(4) Somewhat
(3) Neutral
(2) Somewhat disagree
(1) Strongly agree disagree

Q5A.2

Do you agree or disagree with the following statement?

Lower-income people deserve to have stable homes in the Cully neighborhood.
(5) Strongly
(4) Somewhat
(3) Neutral
(2) Somewhat
(1) Strongly agree agree disagree disagree

Q5A.3

Do you agree or disagree with the following statement?

Housing should generally be treated as a commodity on the market. People should have access to whatever housing they can afford to pay for (as with cars and groceries).

$\square$
(1) Strongly
(2) Somewhat
(3) Neutral
(4) Somewhat disagree
(5) Strongly agree

Q5A.4

Do you agree or disagree with the following statement?

Housing should generally be treated as a public good. Everyone should have access to housing, no matter how much they can afford to pay (as with schools and parks).

(5) Strongly agree
(4) Somewhat
(3) Neutral agree
(3)
(2) Somewhat disagree
(1) Strongly disagree 
SECTION 5B: Acknowledgement of Unjust Circumstances (Consciousness Level 2)

Composite Scale of 4-20

High score $=$ Respondent recognizes the prevalence of unjust housing circumstances

\section{Q5B.1}

Do you agree or disagree with the following statement?

In general, the housing market is working well for low-income people in the Cully neighborhood.

○

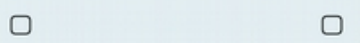
(1) Strongly
(2) Somewhat
(3) Neutral
(4) Somewhat disagree
(5) Strongly agree agree disagree

\section{Q5B.2^}

Do you agree or disagree with the following statement?

Rising rents are causing low-income families in Cully to lose their homes.

\begin{tabular}{|c|c|c|c|c|}
\hline ๑ & ○ & ○ & ० & 口 \\
\hline $\begin{array}{l}\text { (5) Strongly } \\
\text { agree }\end{array}$ & $\begin{array}{l}\text { (4) Somewhat } \\
\text { agree }\end{array}$ & (3) Neutral & $\begin{array}{l}\text { (2) Somewhat } \\
\text { disagree }\end{array}$ & $\begin{array}{l}\text { (1) Strongly } \\
\text { disagree }\end{array}$ \\
\hline
\end{tabular}

\section{Q5B.3*}

Do you agree or disagree with the following statement?

It is getting harder for low-income families to own a home in Cully.

$\square$

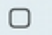

$\square$
(5) Strongly
(4) Somewhat
(3) Neutral
(2) Somewhat disagree
(1) Strongly
agree agree disagree

Q5B.4

Do you agree or disagree with the following statement? If things don't change, Cully will become a neighborhood where only wealthy people can afford to live.
(5) Strongly
(4) Somewhat
(3) Neutral
(2) Somewhat disagree
(1) Strongly agree agree disagree

.


SECTION 5C: Recognition of Unjust System (Consciousness Level 3)

Composite Scale of 4-20

High score $=$ Respondent recognizes unjust circumstances as symptoms of unjust system

Q5C.1* / Higher score indicates understanding that the market system produces unjust outcomes Do you agree or disagree with the following statement?

The value of homes is going up in Cully. Overall, this is good for the neighborhood.
(1) Strongly

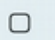
agree
(2) Somewhat
(3) Neutral
$\square$
$\square$

Q5C.2^/ Higher score indicates understanding that the market system produces unjust outcomes Do you agree or disagree with the following statement?

Rents are going up in Cully. Overall, this is good for the neighborhood.
(1) Strongly
(2) Somewhat
(3) Neutral
(4) Somewhat disagree
(5) Strongly disagree

Q5C.3* / Higher score indicates understanding of systemic roots of unjust outcomes When the cost to buy a house is too high for a low-income family to afford, who is most to blame? Select one option:

$\square \quad$ (1) The low-income family, because they don't have enough money to buy the house.

$\square \quad$ (2) The seller, because they set such a high price.

(3) No one is to blame; this is how the market works.

$\square$ (4) The politicians, because they haven't done anything to limit the price that a house can be sold for.

(5) The entire housing system is to blame, because it allows homeowners to make a profit by selling for the highest possible price.

Q5C.4^ / Higher score indicates understanding of systemic roots of unjust outcomes

When the rent goes up and a low-income family is forced to move out, who is most to blame? Select one option:

(1) The low-income family, because they don't have enough money to pay the rent.

(2) The landlord, because they raised the rent so high.

(3) No one is to blame; this is how the market works.

(4) The politicians, because they haven't done anything to prevent the rent increase.

(5) The entire housing system is to blame, because it allows landlords to make a profit by raising the rent. 
SECTION 5D: Recognition of Inter-Group Conflict (Consciousness Level 4)

Composite Scale of 4-20

High score $=$ Respondent acknowledges zero-sum nature of housing interests between groups

Q5D.1* / Higher score indicates understanding of opposing, zero-sum interests between groups Do you agree or disagree with the following statement?

When property values go up, homeowners benefit at the expense of people who don't own homes.
(5) Strongly
$\square$
$\square$ agree
(4) Somewhat
(3) Neutral
(2) Somewhat disagree
(1) Strongly agree disagree

Q5D.2^ / Higher score indicates understanding of opposing, zero-sum interests between groups Do you agree or disagree with the following statement?

When rents go up, landlords benefit at the expense of renters.
(5) Strongly
(4) Somewhat
(3) Neutral
(2) Somewhat
(1) Strongly agree agree disagree disagree

Q5D.3 / Higher score indicates recognition that some benefit at the expense of others Do you agree or disagree with the following statement? Rising housing costs hurt everyone.

$\square$
(1) Strongly agree

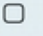

(2) Somewhat agree
(3) Neutral

Q5D.4 / Higher score indicates recognition that property owners' wealth comes from renters and buyers

Do you agree or disagree with the following statement?

In order for everyone to have stable housing that they can afford, property owners will need to lose some of their wealth.
(5) Strongly
(4) Somewhat
agree
(3) Neutral
(2) Somewhat disagree
(1) Strongly disagree 


\section{SECTION 6: Support for Housing Market Interventions}

Composite Scale of 6.5-29.5

High score $=$ Respondent supports measures that reduce the commodity nature of housing

\section{Q6.1}

Do you agree or disagree with the following statement?

More housing should be owned by the government and non-profit organizations, instead of by families and companies.

$\square$

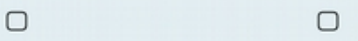
(5) Strongly
(4) Somewhat
(3) Neutral
(2) Somewhat
(1) Strongly agree agree disagree disagree

Q6.2^

Do you agree or disagree with the following statement? There should be new laws to limit rent increases.

$\square$
(5) Strongly
(4) Somewhat
(3) Neutral
(2) Somewhat
(1) Strongly agree agree
disagree disagree

Q6.3*

Do you agree or disagree with the following statement?

There should be new laws to limit how much a homeowner can sell their home for.

$\square$
(5) Strongly
(4) Somewhat
(3) Neutral
(2) Somewhat disagree
(1) Strongly
agree agree disagree

Q6.4*

Do you agree or disagree with the following statement?

Homeowners who make a profit by selling their homes should pay higher taxes, in order to create funds for affordable housing.
(5) Strongly
(4) Somewhat
(3) Neutral
(2) Somewhat disagree
(1) Strongly agree disagree

Q6.5^

Do you agree or disagree with the following statement?

Landlords who make a profit by selling an apartment building or raising the rent should pay higher taxes in order to create funds for affordable housing.

$\square$
(5) Strongly
(4) Somewhat
(3) Neutral
(2) Somewhat
(1) Strongly
agree agree disagree disagree 
Q6.6* / Scores compatible with $1-5$ scale: 4.5 is average of 4 and $5 ; 1.5$ is average of 1 and 2 In a perfect world, which of these two systems for homeownership would be best for the Cully neighborhood?

$\square \quad$ (4.5) It is more affordable to buy a home, because homeowners cannot make a profit when they sell. The cost of buying a house is lower, so more low-income families can afford to buy. But when you sell your house, you are not allowed to sell it for more than you paid when you bought it. This keeps the house affordable for future buyers.

$\square \quad$ (1.5) It is more expensive to buy a home, because homeowners can make a profit when they sell. The cost of buying a house is higher, so fewer low-income families can afford to buy. But if you are able to buy a house, you can sell it in the future for a higher price than you paid when you bought it. This allows your family to gain wealth.

$\square$ (3) I have no preference. 
SECTION 7: Personal Housing History

Composite Scale of 0-4

High score $=$ Respondent has been privileged by the status quo housing system

\section{Q7.1: $N O=1$}

Have you ever been homeless? Select all that apply:

$\square$ NO $\square$ YES, when I was growing up $\square$ YES, as an adult

Q7.2: $Y E S=1$

Did your family ever own your own home when you were growing up?

$\square$ No $\square$ Yes

\section{Q7.3: NO=1}

As an adult, have you ever lost your housing or been forced to move?

$\square$ NO If YES, why? Select all that apply:

$\square$ Eviction $\square$ Rent increase $\square$ Foreclosure $\square$ Other:

\section{Q7.4: YES=1}

As an adult, have you ever made a profit by owning a home that gained value after you bought it? Either your current home, or a home that you owned in the past.

$\square$ No $\square$ Yes 


\section{SECTION 8: Demographics}

\section{Q8.1}

Have you ever lived in the Cully neighborhood? Select one option:

$\square$ I currently live in Cully $\quad \square$ I used to live in Cully, but not now $\quad$ I have never lived in Cully

\section{Q8.2}

What is the zip code where you currently live?

Q8.3

What gender do you identify with?

$\square$ Female $\square$ Male $\square$ Non-binary $\square$ I prefer not to respond

Q8.4

What race or ethnic group do you identify with? Select one or more:
B Black/African American
$\square$ African
$\square$ Asian
- Native American/Indigenous
$\checkmark$ Pacific Islander
$\square$ White
$\square$ Other:
$\checkmark$ Latino/Hispanic
$\square$ I prefer not to respond

Q8.5

How many people in each age group live in your home (including yourself)?

0-17 years old:

18-34 years old:

35-49 years old:

50-64 years old:

65 years and older:

Q8.6

How much does your household pay for your housing each month? Include rent or mortgage and utilities (water, garbage, electricity)

$\begin{array}{lllll}\square & \square & \square & \square & \square \\ \text { Less than } \$ 500 & \$ 500-\$ 999 & \$ 1000-\$ 1499 & \$ 1500-\$ 1999 & \$ 2000 \text { or more } \\ \text { Q8.7 } & & & \\ \text { What is your approximate annual household income? } & & \\ \square & \square & \square & \square & \square \\ \text { Less than } \$ 25,000 & \$ 25,000-49,999 & \$ 50,000-74,999 & \$ 75,000-99,999 & \$ 100,000 \text { or more }\end{array}$




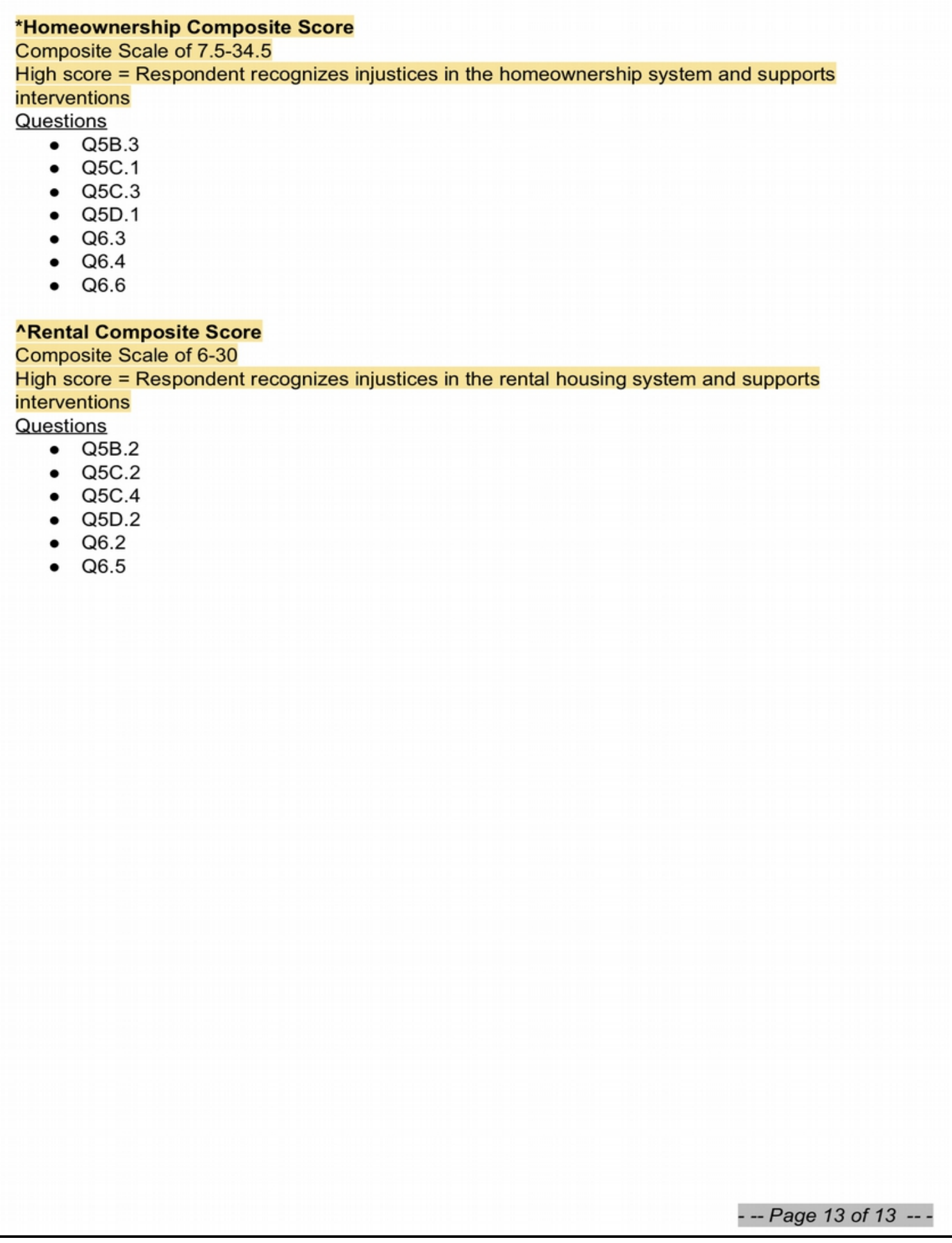

